\title{
Estimating net photosynthesis and productivity of a loblolly pine forest grown with carbon dioxide enrichment
}

Clint J. Springer

West Virginia University

Follow this and additional works at: https://researchrepository.wvu.edu/etd

\section{Recommended Citation}

Springer, Clint J., "Estimating net photosynthesis and productivity of a loblolly pine forest grown with carbon dioxide enrichment" (2004). Graduate Theses, Dissertations, and Problem Reports. 2127.

https://researchrepository.wvu.edu/etd/2127

This Dissertation is protected by copyright and/or related rights. It has been brought to you by the The Research Repository @ WVU with permission from the rights-holder(s). You are free to use this Dissertation in any way that is permitted by the copyright and related rights legislation that applies to your use. For other uses you must obtain permission from the rights-holder(s) directly, unless additional rights are indicated by a Creative Commons license in the record and/ or on the work itself. This Dissertation has been accepted for inclusion in WVU Graduate Theses, Dissertations, and Problem Reports collection by an authorized administrator of The Research Repository @ WVU.

For more information, please contact researchrepository@mail.wvu.edu. 
Estimating Net Photosynthesis and Productivity of a Loblolly Pine Forest Grown with Carbon Dioxide Enrichment

\section{Clint J. Springer}

Dissertation submitted to the

Eberly College of Arts and Sciences

at West Virginia University

in partial fulfillment of the requirements

for the degree of

Doctor of Philosophy

in

Environmental and Evolutionary Biology

Richard B. Thomas, Ph. D., Chair

Jonathan Cumming, Ph. D.

Ray R. Hicks, Jr., Ph. D.

James B. McGraw, Ph. D.

William T. Peterjohn, Ph. D.

Department of Biology

Morgantown, West Virginia

2004

Keywords: carbon dioxide, FACE, photosynthesis, down-regulation, NPP 


\section{Estimating Net Photosynthesis and Productivity of a Loblolly Pine Forest Grown with Carbon Dioxide Enrichment}

\section{Abstract}

\section{Clint J. Springer}

I examined the long-term effects of elevated $\mathrm{CO}_{2}$ on the leaf chemistry and photosynthesis of four species growing in the understory and two species growing in the overstory at the Duke Forest FACE experiment. I then used these measurements to parameterize a process based forest productivity model, PnET-II, in order to model the net primary productivity of the portions of the forest growing under ambient and elevated $\mathrm{CO}_{2}$. Finally, I performed a greenhouse study that examined the effects of elevated $\mathrm{CO}_{2}$ and water availability on the growth and biomass allocation of loblolly pine seedlings from four distinct geographic locations. At the Duke FACE experiment I found a continued stimulation of photosynthesis with elevated $\mathrm{CO}_{2}$ in each species I measured. However the effect of elevated $\mathrm{CO}_{2}$ on photosynthesis of these species did depend on canopy position, season, and year. I observed no $\mathrm{CO}_{2}$-induced changes in leaf chemistry or morphology. Modeled estimates of net primary productivity of the Duke Forest were in good agreement with those measured at the Duke FACE experiment. Estimates of net primary productivity of the portions of the forest grown under elevated $\mathrm{CO}_{2}$ were much greater than the estimates of the portions of the forest grown under ambient $\mathrm{CO}_{2}$. I also found that future climatic conditions expected in North Carolina, USA should alter forest net primary productivity overall but would not alter the response of forest productivity to elevated $\mathrm{CO}_{2}$. In the study of the response of loblolly pine seedlings from different geographic locations to elevated $\mathrm{CO}_{2}$, I found significantly higher biomass in elevated $\mathrm{CO}_{2}$-grown seedlings but I found no evidence of provenance specificity in the growth response to elevated $\mathrm{CO}_{2}$. Decreased water availability did decrease the plant growth and alter biomass allocation irrespective of geographic location and growth $\mathrm{CO}_{2}$ concentration. However, I also concluded that a more detailed analysis is needed with respect to provenance specific responses of loblolly pine to variables of climate change such as $\mathrm{CO}_{2}$ and water availability. Overall my studies revealed that the stimulation of photosynthesis and productivity at the Duke Forest FACE experiment has persisted into the latter years of the experiment and, with no changes in leaf chemistry, no loss of stimulation is expected. 


\section{ACKNOWLEDGEMENTS}

First, I would like to thank my mentor and friend, Dr. Richard Thomas for his support, advice, and especially his friendship. I also wish to extend a sincere thank you to my advisory committee, Dr. Jonathan Cumming, Dr. Ray Hicks, Dr. James McGraw, and Dr. William Peterjohn. They have all provided invaluable advice and support.

I am also grateful to those who have assisted me in the field and in the lab. A few individuals stand out, Gera Jochum, Jeff Pippen, Chris Feathers, and Dr. Jeff Herrick.. I would also like to thank the staff of the Duke Forest FACE experiment for this tireless effort to keep the experiment running at all hours of the day.

I would also like to thank my wonderful wife, Terica, without your lab skills I would still be wrapping samples. More importantly I want to thank you for your love and support through this process, without you my dreams would have no meaning. I love you.

Finally, I would like to thank my mother, Debra Springer, for all of the years of love and encouragement. I also want to thank you for passing your love of learning onto me. You will eternally serve as a source of inspiration for me. 


\section{TABLE OF CONTENTS}

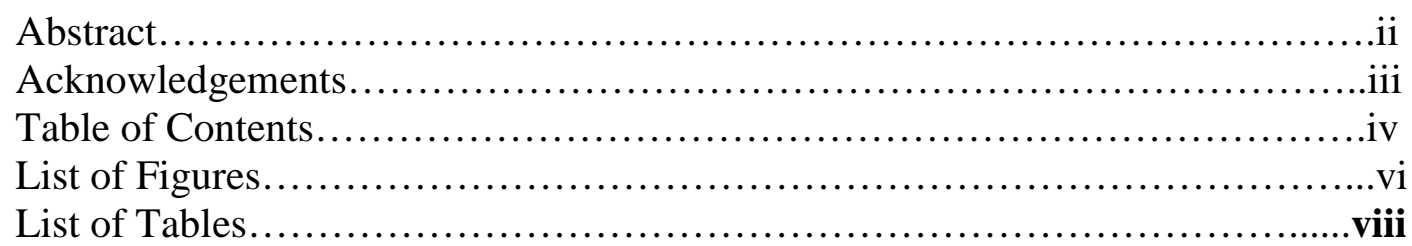

\section{Chapter 1}

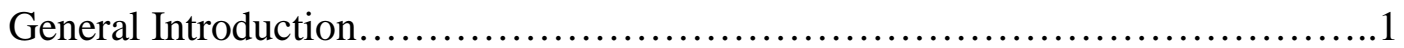

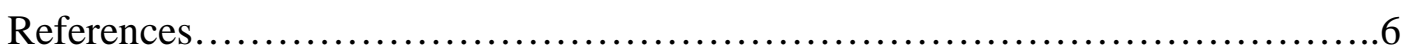

\section{Chapter 2}

Photosynthesis and foliar nitrogen relationships after six years of $\mathrm{CO}_{2}$ enrichment at the Duke Forest FACE experiment.....................................8

Abstract.................................................................. 9

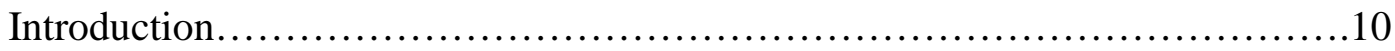

Methods................................................................ 13

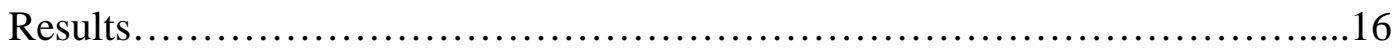

Discussion............................................................. 19

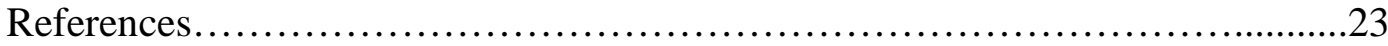

\section{Chapter 3}

Photosynthetic responses of four understory tree species after 7 years of $\mathrm{CO}_{2}$ enrichment in the Duke Forest FACE experiment...........................40

Abstract............................................................... 41

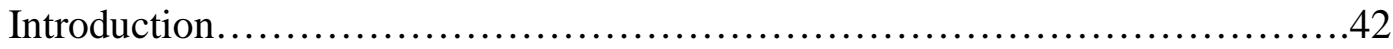

Methods.................................................................. 45

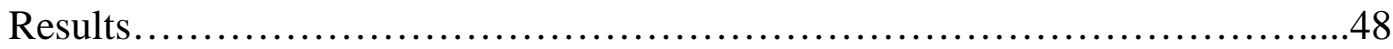

Discussion.......................................................... 50

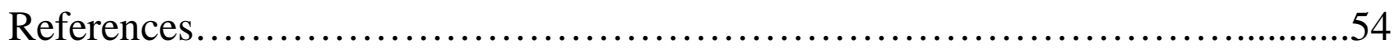

\section{Chapter 4}

Growth response of Pinus taeda seedlings from four provenances to water availability and elevated carbon dioxide.................................68

Abstract.................................................................69

Introduction..................................................... 70 


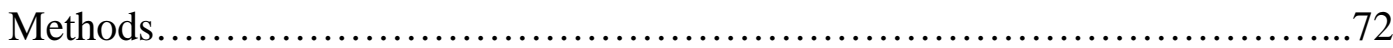

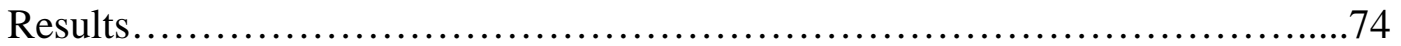

Discussion........................................................... 74

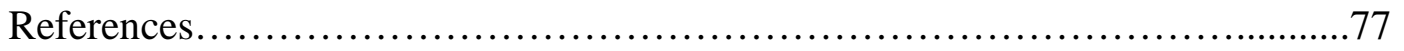

\section{Chapter 5}

Net primary productivity of the first seven years of treatment at the Duke Forest FACE experiment estimated using PnET-II...............................83

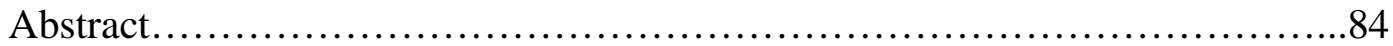

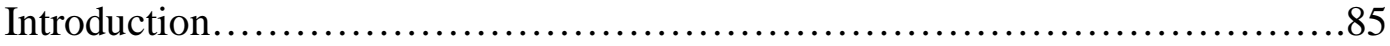

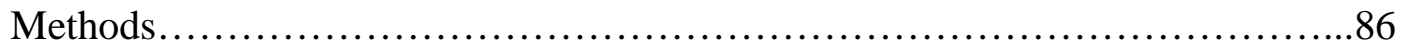

Results \& Discussion..................................................... 89

References............................................................. 93

General Conclusions.................................................... 110

References............................................................... 113 


\section{LIST OF FIGURES}

Figure 2.1. Light-saturated net photosynthetic rates $\left(A_{\text {sat }}\right)$ measured at the growth $\mathrm{CO}_{2}$ concentration versus foliar $\mathrm{N}$ concentrations $\left(\left[\mathrm{N}_{\mathrm{a}}\right]\right)$ of loblolly pine, sweetgum, red maple, hickory, and redbud grown under ambient $\mathrm{CO}_{2}$ (closed circles, solid line) and elevated $\mathrm{CO}_{2}$ (open circles, dashed line). Measurements were conducted in (a) early summer 1999, (b) late summer 1999, (c) early summer 2001, (d) late summer 2001, (e) early summer 2002, (f) late summer 2002. Regression equations of these relationships

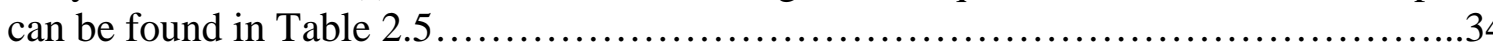

Figure 2.2. Light-saturated net photosynthetic rates $\left(A_{\text {sat }}\right)$ measured at the growth $\mathrm{CO}_{2}$ concentration versus foliar $\mathrm{N}$ concentrations $\left(\left[\mathrm{N}_{\mathrm{a}}\right]\right)$ of loblolly pine, sweetgum, red maple, hickory, and redbud grown under ambient $\mathrm{CO}_{2}$ (closed circles, solid line) and elevated $\mathrm{CO}_{2}$ (open circles, dashed line). Data were pooled to calculate a single relationship for each $\mathrm{CO}_{2}$ treatment across all measurement dates. Regression equations

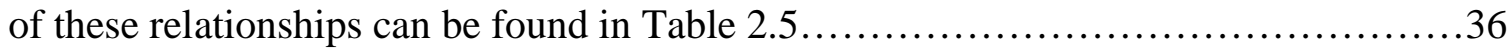

Figure 2.3. Light-saturated net photosynthetic rates $\left(A_{\text {sat }}\right)$ versus foliar $\mathrm{N}$ concentrations ([ $\left.\left.\mathrm{N}_{\mathrm{a}}\right]\right)$ of loblolly pine, sweetgum, red maple, hickory, and redbud grown under ambient $\mathrm{CO}_{2}$ (closed circles, solid line) and elevated $\mathrm{CO}_{2}$ (open circles, dashed line). Measurements were made at two common $\mathrm{CO}_{2}$ concentrations of $380 \mu \mathrm{ll}^{-1} \mathrm{CO}_{2}\left(A_{380}\right)$ and $580 \mu \mathrm{l} \mathrm{l}^{-1} \mathrm{CO}_{2}\left(A_{580}\right)$ during late summer $2001(\mathrm{a}, \mathrm{b})$ and early summer $2002(\mathrm{c}, \mathrm{d})$ and late summer 2002 (e,f). Regression equations of these relationships can be found in

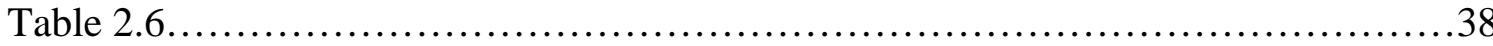

Figure 3.1. Photosynthetic-light response curves of four species of understory saplings growing under ambient ( $380 \mu 11^{-1} \mathrm{CO}_{2} ;$ closed circles $)$ and elevated atmospheric $\mathrm{CO}_{2}$ $\left(\sim 580 \mu \mathrm{l}^{-1}\right.$; open circles) in June of 2003 at the Duke Forest FACE experiment. Each point is a mean $( \pm 1 \mathrm{SE})$ of four to six measurements...............................60

Figure 3.2. Photosynthetic-light response curves of four species of understory saplings growing under ambient $\left(\sim 380 \mu 11^{-1} \mathrm{CO}_{2} ;\right.$ closed circles $)$ and elevated atmospheric $\mathrm{CO}_{2}$ $\left(\sim 580 \mu \mathrm{l} \mathrm{I}^{-1}\right.$; open circles $)$ in September of 2003 at the Duke Forest FACE experiment. Each point is a mean $( \pm 1 \mathrm{SE})$ of four to six measurements.

Figure 3.3. Chlorophyll fluorescence-PPFD relationships of four species of understory saplings growing under ambient $\left(\sim 380 \mu \mathrm{l}^{-1} \mathrm{CO}_{2}\right.$; closed circles $)$ and elevated atmospheric $\mathrm{CO}_{2}\left(\sim 580 \mu \mathrm{l}^{-1}\right.$; open circles $)$ in June of 2003 at the Duke Forest FACE experiment. Each point is a mean $( \pm 1 \mathrm{SE})$ of four to six measurements................64

Figure 3.4. Chlorophyll fluorescence-PPFD relationships of four species of understory saplings growing under ambient $\left(\sim 380 \mu 11^{-1} \mathrm{CO}_{2}\right.$; closed circles $)$ and elevated atmospheric $\mathrm{CO}_{2}\left(\sim 580 \mu \mathrm{l}^{-1}\right.$; open circles $)$ in September of 2003 at the Duke Forest FACE experiment. Each point is a mean $( \pm 1 \mathrm{SE})$ of four to six measurements..........66 
Figure 4.1. Total biomass of loblolly pine seedlings grown in ambient and elevated $\mathrm{CO}_{2}$ under three levels of water availability (low, intermediate, and high) originiating from a) the lost pines region, b) coastal North Carolina, c) the piedmont of the southeastern United States, and d) east Texas. Values are the means \pm 1 SE...

Figure 5.1. Net primary productivity (NPP) of portions of the Duke Forest FACE experiment growing under ambient (closed circles, solid line) and elevated (open circles, dashed line) $\mathrm{CO}_{2}$ from 1997 to 2003 estimated using the PnET-II forest productivity model. Values represent model output \pm 1 S.E. determined by using the lower and upper standard errors of model parameters measured by the investigator

Figure 5.2. Relationship between the stimulation of NPP due to elevated $\mathrm{CO}_{2}$ versus mean growing season temperature. Regression equation: $\mathrm{y}=1.05+0.005 \mathrm{x}, R^{2}=0.18$, $P=0.1689$

Figure 5.2. Relationship between the stimulation of NPP due to elevated $\mathrm{CO}_{2}$ versus annual precipitation. Regression equation: $\mathrm{y}=1.14+0.00016 \mathrm{x}, R^{2}=0.17, P=0.1459$. Figure 5.3. Modeled NPP of the Duke Forest FACE experiment grown under ambient (closed bars) and elevated (open bars) $\mathrm{CO}_{2}$ using a control climate scenario and three climate change scenarios, temperature only (Temp), precipitation only (Precip), and both

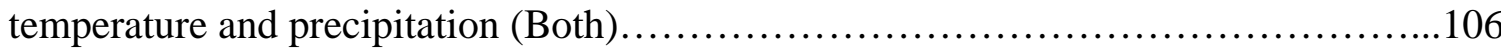

Figure 5.4. The stimulation of NPP by $\mathrm{CO}_{2}$ enrichment versus $\%$ foliar $\mathrm{N}$ concentration. The stimulation of NPP by $\mathrm{CO}_{2}$ enrichment reaches zero at $0.70 \%$ foliar $\mathrm{N}$ concentraton. .108 


\section{LIST OF TABLES}

Table 2.1. Light-saturated net photosynthesis of needles and leaves located at the top (sun) and bottom (shade) of P.taeda (PITA) and L. styraciflua (LIST) growing in the overstory at the Duke Forest FACE experiment under ambient (AMB) and elevated (ELV) $\mathrm{CO}_{2}$. Each value is the mean of three treatment rings for both loblolly pine and sweetgum $( \pm 1 \mathrm{SE})$ measured at the growth $\mathrm{CO}_{2}$ concentration in the early and late

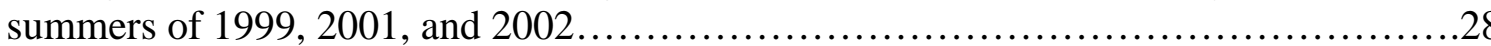

Table 2.2. Light-saturated net photosynthesis understory A. rubrum (ACRU), C. glabra (CAGL), C. canadensis (CECA), and L. styraciflua (LIST) growing in the understory at the Duke Forest FACE experiment under ambient (AMB) and elevated (ELV) $\mathrm{CO}_{2}$. Each value is the mean of three treatment rings $( \pm 1 \mathrm{SE})$ measured at the growth $\mathrm{CO}_{2}$ concentration in the early and late summers of 1999, 2001, and 2002

Table 2.3. Leaf mass per unit area (LMa), mass-based foliar $\mathrm{N}$ concentration $([\mathrm{N}] \mathrm{m})$ and area based foliar $\mathrm{N}$ concentration $([\mathrm{N}] \mathrm{a})$ at the top and bottom of the canopy of loblolly pine (PITA) and sweetgum (LIST) trees growing in the forest overstory of the Duke Forest FACE experiment. Measurements were made twice each year (early and late summer) during 1999, 2001, and 2002 in both ambient (AMB) and elevated (ELV) $\mathrm{CO}_{2}$

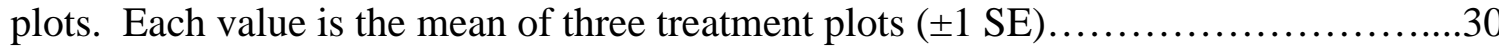

Table 2.4. Leaf mass per unit area (LMa), mass-based foliar $\mathrm{N}$ concentrations $([\mathrm{N}] \mathrm{m})$ and area based foliar $\mathrm{N}$ concentration $\left([\mathrm{N}]_{\mathrm{a}}\right)$ of red maple (ACRU), hickory (CAGL), redbud (CECA), and sweetgum (LIST) trees growing in the forest understory of the Duke Forest FACE experiment. Measurements were made twice each year (early and late summer) during 1999, 2001, and 2002 in both ambient (AMB) and elevated (ELV) $\mathrm{CO}_{2}$ plots. Each value is the mean of three treatment plots $( \pm 1 \mathrm{SE})$

Table 2.5. Regression components of the $A_{\text {sat }}-N$ relationships in the forest canopy of the Duke Forest FACE experiment measured during 1999, 2001, and 2002 in early and late summer.

Table 2.6. Regression components of $A_{s a t}-N$ relationships measured at two common $\mathrm{CO}_{2}$ concentrations in the forest canopy of the Duke Forest FACE experiment during 1999, 2001, and 2002 in early and late summer.

Table 3.1. Dark respiration $\left(R_{d}\right)$, apparent quantum efficiency $\left(Q_{e}, \mathrm{~mol} \mathrm{~mol}^{-1}\right)$, light saturated maximum photosynthesis $\left(\mu \mathrm{mol} \mathrm{CO} \mathrm{C}^{-2} \mathrm{~s}^{-1}\right)$, and the light compensation point $\left(\Gamma, \mu \mathrm{mol} \mathrm{m} \mathrm{m}^{-2}\right.$ ) of A. rubrum (ACRU), Carya glabra (CAGL), Cercis canadensis (CECA), and Liquidambar styraciflua (LIST) grown in ambient and elevated $\mathrm{CO}_{2}$. Measurements were made in June and September 2003 and each value is the mean of 4 to

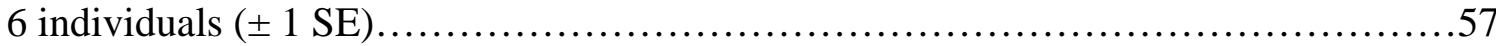


Table 3.2. Carboxylation efficiency $\left(\mathrm{Vc}_{\max }, \mu \mathrm{mol} \mathrm{CO}_{2} \mathrm{~m}^{-2} \mathrm{~s}^{-1}\right)$, electron transport efficiency $\left(J_{\max }, \mu \mathrm{mol} \mathrm{CO}_{2} \mathrm{~m}^{-2} \mathrm{~s}^{-1}\right)$, and the ratio of $\mathrm{Vc}_{\max } / J_{\max }$ of $A$. rubrum (ACRU), Carya glabra (CAGL), Cercis canadensis (CECA), and Liquidambar styraciflua (LIST) grown in ambient and elevated $\mathrm{CO}_{2}$. Measurements were made in June and September 2003 and each value is the mean of 4 to 6 individuals $( \pm 1 \mathrm{SE})$

Table 3.3. Specific leaf area (SLA, $\left.\mathrm{cm}^{2} \mathrm{~g}^{-1}\right)$, foliar nitrogen concentration $\left([\mathrm{N}]_{\text {mass }}, \mathrm{mg} \mathrm{g}^{-}\right.$ ${ }^{1}$; $\left([\mathrm{N}]_{\text {area }}, \mathrm{g} \mathrm{m}^{-2}\right)$ total chlorophyll concentration $\left(\mathrm{Chl}_{\text {mass }}, \mathrm{mg} \mathrm{g}^{-1} ; \mathrm{Chl}_{\text {area }}, \mu \mathrm{g} \mathrm{cm}^{-2}\right)$, chlorophyll a/b ratio $\left(\mathrm{Chl}_{a / b}\right)$ and dark-adapted chlorophyll fluorescence $\left(\mathrm{F}_{\mathrm{v}} / \mathrm{F}_{\mathrm{m}}, \mathrm{Rel}\right.$.) of A. rubrum (ACRU), Carya glabra (CAGL), Cercis canadensis (CECA), and Liquidambar styraciflua (LIST) grown in ambient and elevated $\mathrm{CO}_{2}$. Measurements were made in June and September 2003 and each value is the mean of 4 to 6 individuals $( \pm 1 \mathrm{SE})$

Table 4.1. Biomass allocation of loblolly pine seedlings from four distinct provenances grown under ambient and elevated $\mathrm{CO}_{2}$ and three levels of water availability (high, intermediate (Int), and low). Each value represent the mean of each group \pm 1 SE....8 82

Table 5.1. Duke Forest FACE experiment specific parameters that differed from earlier modeling efforts of Aber and Federer (1992) and Sun et al. (2000) used to estimate net primary productivity of the portions of the forest growing under ambient and elevated $\mathrm{CO}_{2}$ using the PnET-II forest productivity model 
Chapter 1

General Introduction

- 1 - 
Fossil fuel combustion and land use conversion have increased atmospheric carbon dioxide $\left(\mathrm{CO}_{2}\right)$ concentrations from approximately 280 ? mol mol${ }^{-1}$ since the beginning of the industrial revolution to a current concentration of approximately $375 ? \mathrm{~mol} \mathrm{~mol}^{-1} \mathrm{CO}_{2}$. Final projections of future atmospheric $\mathrm{CO}_{2}$ concentrations are uncertain and constantly changing; however, a doubling of the pre-industrial revolution value is expected some time in the mid- $21^{\text {st }}$ century (IPCC 2001). This doubling in $\mathrm{CO}_{2}$ concentration and changes in the concentrations of other "greenhouse" gases in the atmosphere are expected to drive a concomitant $3-7^{\circ} \mathrm{C}$ increase in global mean temperature and cause significant alterations to regional precipitation patterns (IPCC 2001).

Increased atmospheric $\mathrm{CO}_{2}$ typically increases photosynthesis and productivity of plants when other factors, such as water and nutrient availability are not limiting (Bazzaz 1990). This is especially true for plants which utilize the $\mathrm{C}_{3}$ photosynthetic pathway (Ward and Strain 1999), because $\mathrm{CO}_{2}$, a primary substrate of photosynthesis, is typically available in sub-saturating quantities (Drake et al. 1997). Photosynthesis, or gross primary productivity, represents the uptake side of the global carbon $(C)$ cycle, whereas respiration returns $\mathrm{CO}_{2}$ to the atmosphere. The difference between uptake of $\mathrm{CO}_{2}$ and the return of $\mathrm{CO}_{2}$ to the atmosphere by plants in terrestrial ecosystems is known as terrestrial net primary productivity (NPP) (Schlesinger 1997). Because the uptake of carbon from the atmosphere is increased by elevated atmospheric $\mathrm{CO}_{2}$, the net primary productivity of many ecosystems is also expected to increase in the future.

Forest ecosystems account for $\sim 80 \%$ of annual terrestrial NPP (Schlesinger 1997). Because of the important role of forests in the global $C$ cycle, developing reliable predictions about future forest productivity under increased atmospheric $\mathrm{CO}_{2}$ and the associated changes in 
the physical environment that control ecosystem productivity have been given a high priority by many scientists and policymakers. However, the ability to predict future concentrations of atmospheric $\mathrm{CO}_{2}$ and ecosystem productivity rely heavily on our understanding of the physiological, biochemical, and biogeochemical process that control the response of forest ecosystem NPP to elevated atmospheric $\mathrm{CO}_{2}$. Development of Free- $\underline{\text { Air }} \underline{\text { Carbon Dioxide }}$ Enrichment (FACE) technology and its implementation at the FACTS-I Duke Forest FACE experiment (Hendrey et al. 1999) allows examination of the responses of an intact loblolly pine forest to elevated $\mathrm{CO}_{2}$ while operating under the full suite of biotic and abiotic processes of a forest ecosystem. Since fumigation began in 1996, the Duke Forest FACE experiment has produced numerous studies on the response of forest ecosystems to elevated $\mathrm{CO}_{2}$ from the molecular to the ecosystem level. However, after several years of $\mathrm{CO}_{2}$ treatment at the Duke Forest FACE study, large uncertainties remain regarding the effects of $\mathrm{CO}_{2}$ enrichment on carbon budgets of forest ecosystems. The primary objectives of this study are to provide a more complete understanding of the photosynthetic response of trees growing throughout the forest canopy at the Duke FACE experiment to elevated $\mathrm{CO}_{2}$ and to provide a modeled estimate of the net primary productivity of the portion of the loblolly pine forest growing in both ambient and elevated $\mathrm{CO}_{2}$ environments using PnET-II, a process-based forest productivity model (Aber and Federer 1992).

Modeled estimates of NPP using PnET-II rely on a fundamental relationship between net photosynthesis and leaf N concentrations (Field and Mooney 1986, Evans 1989, Evans and Seemann 1989, Reich et al. 1997). Thus, in order to use this model for the Duke Forest FACE study, I established these relationships in both the ambient and elevated $\mathrm{CO}_{2}$-grown portions of the Duke Forest FACE experiment. These relationships were measured using the two dominant 
overstory species and 4 dominant understory species in the Duke FACE experiment and were measured across multiple years to examine season-to-season and year-to-year variability.

Because of the environmental heterogenity of the Duke FACE experiment, it was also necessary to determine if the response of photosynthesis to elevated $\mathrm{CO}_{2}$ was affected by other environmental variables present in a long-term $\mathrm{CO}_{2}$ enrichment experiment located in a natural field setting. Therefore, I examined several factors that may contribute to variation in the response of photosynthesis to elevated $\mathrm{CO}_{2}$ in this experiment. The first factor I examined was a time-dependent loss of photosynthetic stimulation by elevated $\mathrm{CO}_{2}$ that has been observed in many long-term $\mathrm{CO}_{2}$ enrichment experiments. This decline in photosynthetic response to elevated $\mathrm{CO}_{2}$ is typically associated with a decline in foliar $\mathrm{N}$ concentration. I performed an experiment to determine if either a decline in the photosynthetic response to elevated $\mathrm{CO}_{2}$ or a $\mathrm{CO}_{2}$-induced reduction in foliar $\mathrm{N}$ concentration had occurred after six years of $\mathrm{CO}_{2}$ treatment. To complete this experiment, I measured photosynthesis-foliar $\mathrm{N}$ relationships at two common $\mathrm{CO}_{2}$ concentrations over three measurement periods vertically through the forest canopy. I then used the comparison of these relationships measured at common $\mathrm{CO}_{2}$ concentrations to detect if a loss of photosynthetic capacity had occurred in elevated $\mathrm{CO}_{2}$-grown trees and if this loss of capacity was linked to changes in foliar $\mathrm{N}$ concentration. I hypothesized that after 6 years of $\mathrm{CO}_{2}$ enrichment I would observe a decline in the photosynthetic capacity of elevated $\mathrm{CO}_{2}$-grown trees versus ambient $\mathrm{CO}_{2}$-grown trees and this decline would be related to a reduction in foliar $\mathrm{N}$ concentration.

The second environmental factor contributing a large amount of variation in the photosynthetic response to elevated $\mathrm{CO}_{2}$ is the effect of the highly dynamic, and unpredictable, light environment in the forest understory on the $\mathrm{CO}_{2}$ response of photosynthesis of species 
growing in the forest understory. In this experiment I carried out a detailed analysis of the physiological mechanisms that control photosynthesis with respect to $\mathrm{CO}_{2}$ and light availability. I then compared the results of this study to those of a study carried out in the first year of the $\mathrm{CO}_{2}$ enrichment at the Duke FACE experiment using similar methods to understand the changes that may have occurred in the mechanisms controlling understory photosynthesis after 7 years of $\mathrm{CO}_{2}$ enrichment. I hypothesized that after 7 years of $\mathrm{CO}_{2}$ enrichment I would observe a change in the investment of resources in the leaf toward light harvesting and away from $\mathrm{CO}_{2}$ uptake because of the decrease in $\mathrm{CO}_{2}$ limitation of photosynthesis found in an elevated $\mathrm{CO}_{2}$ environment and that this reinvestment would lead to a loss of photosynthetic stimulation by elevated $\mathrm{CO}_{2}$.

The effects of two other factors, genetic variation and water availability that may contribute to the variability found in the response of tree growth to elevated $\mathrm{CO}_{2}$, were examined simultaneously in a greenhouse experiment. This study investigated the biomass production of loblolly pine seedlings from four distinct geographic locations and three levels of water availability. In this study I hypothesized that I would observe a strong genotype by environment interaction where seedlings originating from wet areas would show a greater response to elevated $\mathrm{CO}_{2}$ when grown under high water availability and seedlings originating from drier climates would show a greater response to elevated $\mathrm{CO}_{2}$ when grown under drought conditions.- 


\section{References}

Aber, J.D. and A. Federer 1992. A generalized, lumped-parameter model of photosynthesis, evapotranspiration and net primary production in temperate and boreal forest ecosystems. Oecologia. 92:463-474.

Bazzaz, F.A. 1990. The response of natural ecosystems to the rising global $\mathrm{CO}_{2}$ levels. Annual Review of Ecology and Systematics. 21:167-196.

Drake, B., M. Gonzalez-Meler and S. Long 1997. More Efficent Plants: A consequence of rising atmospheric $\mathrm{CO}_{2}$ ? Annual Review of Plant Physiology and Plant Molecular Biology. 48:609-39.

Evans, J. 1989. Photosynthesis and Nitrogen relationships in leaves of C3 plants. Oecologia. 78:9-19.

Evans, J. and J. Seemann 1989. The Allocation of protein in the photosynthetic apparatus; costs, consequences, and control. Photosynthesis:183-205.

Field, C. and H.A. Mooney 1986. The photosynthesis-nitrogen relationship in wild plants. In On the Economy of Plant Form and Function Ed. T.J. Givnish. Cambridge University Press, Cambridge, UK, pp. 25-55.

Hendrey, G.R., D.S. Ellsworth, K.F. Lewin and J. Nagy 1999. A free-air enrichment system for exposing tall forest vegetation to elevated atmospheric $\mathrm{CO}_{2}$. Global Change Biology. 5:293-309.

IPCC 2001. IPCC Third Assessment Report-Climate Change 2001: The Scientific Basis Eds. J.T. Houghton, Y. Ding, D.J. Griggs, M. Noguer, P.J. van der Linden, X. Dai, K. Maskell and C.A. Johnson. Cambridge University Press, Cambridge, UK.

Reich, P.B., M.B. Walters and D.E. Ellsworth 1997. From tropics to tundra: global convergence in plant functioning. Proceedings of the National Academy of Sciences. 94:13730-13734.

Schlesinger, W.H. 1997. Biogeochemistry: An analysis of global change. Academic Press, San Diego. 
Ward, J.K. and B.R. Strain 1999. Elevated CO2 studies: past, present and future. Tree Physiology. 19:211-220. 


\section{CHAPTER 2:}

Photosynthesis and foliar nitrogen relationships after six years of $\mathrm{CO}_{2}$ enrichment at the Duke Forest FACE experiment 


\section{Abstract}

In this study I examined the effects of elevated $\mathrm{CO}_{2}$ on the relationships between lightsaturated photosynthesis $\left(A_{\text {sat }}\right)$ and foliar nitrogen on an area basis $\left(\mathrm{N}_{\mathrm{a}}\right)$ through the canopy of the Duke FACE experiment after six years of $\mathrm{CO}_{2}$ treatment. Light-saturated photosynthesis and foliar $\mathrm{N}$ were measured on two overstory tree species and four understory tree species in ambient and elevated $\mathrm{CO}_{2}$ FACE rings during early and late summer of 1999, 2001, and 2002. Net photosynthetic rates of every species examined in the overstory and understory were stimulated by elevated $\mathrm{CO}_{2}$ at each measurement date. I found no effect of elevated $\mathrm{CO}_{2}$ on foliar $\mathrm{N}_{\mathrm{a}}$ of any of the species. The slope of the $A_{s a t} N$ relationship was $81 \%$ greater in elevated $\mathrm{CO}_{2}$ than in ambient $\mathrm{CO}_{2}$ when averaged across all sample dates, which reflected a differential $\mathrm{CO}_{2}$ effect at the top and bottom of the forest canopy on photosynthesis. $A_{s a t}-N$ relationships in both ambient and elevated $\mathrm{CO}_{2}$-grown trees were compared at two common $\mathrm{CO}_{2}$ concentrations during late summer 2001 and both measurement periods in 2002 to determine if the stimulatory effect of elevated $\mathrm{CO}_{2}$ on photosynthesis had diminished over time At all three sample times, neither the slopes nor the y-intercepts of $A_{\text {sat }} N$ relationships of ambient and elevated CO2-grown trees differed when measured at common $\mathrm{CO}_{2}$ concentrations. Thus, with the observation that foliar $\mathrm{N}$ was not affected by growth in elevated $\mathrm{CO}_{2}$, I concluded that, after six years of $\mathrm{CO}_{2}$ enrichment, overstory and understory trees growing at the Duke Forest FACE experiment show a sustained stimulation of photosynthesis by elevated $\mathrm{CO}_{2}$. These relationships between foliar $\mathrm{N}$ and photosynthesis indicate that any alterations of $\mathrm{N}$ availability under elevated $\mathrm{CO}_{2}$ will have a significant impact on the response of photosynthesis to elevated $\mathrm{CO}_{2}$. 


\section{Introduction}

As atmospheric $\mathrm{CO}_{2}$ enrichment experiments increase in complexity from single plants in pots to intact forest ecosystems using FACE technology, the difficulty in determining the photosynthetic responses to elevated $\mathrm{CO}_{2}$ also increases. For example, the photosynthetic responses of trees in forest ecosystems exposed to $\mathrm{CO}_{2}$ enrichment exhibit a large amount of seasonal variation, especially with respect to temperature (Myers et al. 1999) and precipitation (Gunderson et al. 2002). Light gradients through leaf canopies strongly affect leaf physiology, morphology, and tissue chemistry. Thus, leaves at the top and the bottom of the canopy may respond differentially to elevated $\mathrm{CO}_{2}$ (Herrick and Thomas 1999, Kubiske et al. 2002). In addition, the relative responses to $\mathrm{CO}_{2}$ enrichment differ between species and functional types within a forest ecosystem (Curtis and Wang 1998). It is important to incorporate as many of these sources of variation as possible when determining the $\mathrm{CO}_{2}$ enhancement of photosynthesis because approximations of future forest productivity rely on these values.

Another difficulty in predicting the response of photosynthesis to elevated $\mathrm{CO}_{2}$ involves the common observation in long-term studies that the degree of photosynthetic stimulation by $\mathrm{CO}_{2}$ enrichment sometimes declines over time. Several analyses of elevated $\mathrm{CO}_{2}$ experiments have shown an approximate $20 \%$ reduction in the $\mathrm{CO}_{2}$-stimulation of photosynthesis after longterm exposure to elevated $\mathrm{CO}_{2}$ compared to short-term exposure (Gunderson and Wullschleger 1994, Medlyn et al. 1999). The loss of stimulation is typically characterized by a decline in leaf nitrogen and rubisco (ribulose-1,5-bisphosphate carboxylase/oxygenase), which leads to the reduction of photosynthetic capacity (Long and Drake 1991, Stitt 1991, Bowes 1993, Sage 1994, Norby et al. 1999). Many forest ecosystems are N-limited (Vitousek and Howarth 1991) and greater growth rates and increased resource demands of plants growing in elevated $\mathrm{CO}_{2}$ may 
exacerbate nutrient limitations (Ingestad and Stoy 1982). Consequently, a reduction in the response of photosynthesis to elevated $\mathrm{CO}_{2}$ may be a common occurrence in ecosystems that have a low soil N availability (Radoglou et al. 1992, Tissue et al. 1993, El Kohen and Mousseau 1994, Sage 1994, Curtis et al. 1995), such as piedmont loblolly pine forests (Piatek and Allen 2000, Richter et al. 2000).

One method that examines the response of photosynthesis to elevated $\mathrm{CO}_{2}$ while including the variation in foliar $\mathrm{N}$ concentration throughout the forest canopy is to use the relationship between light-saturated photosynthesis and foliar $\mathrm{N}$ concentration $\left(A_{\text {sat }}-\mathrm{N}\right.$ relationship). This method incorporates the variation caused by the light gradient through a canopy and can be used to examine differential species effects or the canopy as a whole. The $A_{\text {sat }}-N$ relationship has been shown to be robust across a large number of species from a broad range of ecosystems (Field and Mooney 1986, Evans 1989, Reich et al. 1997) and a recent metaanalysis using both deciduous and evergreen tree species found a strong stimulation by elevated $\mathrm{CO}_{2}$ (Peterson and CMEAL participants 1999). In addition, the $A_{\text {sat }}-N$ relationship is indicative of photosynthetic capacity since foliar $\mathrm{N}$ concentrations strongly correlate with rubisco activity and electron transport (Terashima and Evans 1988), including plants grown in ambient and elevated $\mathrm{CO}_{2}$ (Terashima and Evans 1988, Medlyn et al. 1999, Herrick and Thomas 2001). $A_{\text {sat }}-N$ relationships of plants grown at different $\mathrm{CO}_{2}$ concentrations but measured at a common $\mathrm{CO}_{2}$ concentration may be used as a diagnostic tool to detect $\mathrm{CO}_{2}$-related reductions in photosynthetic enhancement before employing a more time consuming and labor intensive examination of photosynthetic down regulation by means of $\mathrm{CO}_{2}$ response curves (von Caemmerer and Farquhar 1981, Farquhar and Sharkey 1982, Sharkey 1985). 
Loblolly pine trees growing in the prototype ring of the Duke Forest FACE experiment showed a diminished growth response to elevated $\mathrm{CO}_{2}$ after four years of $\mathrm{CO}_{2}$ treatment and it was concluded that this loss of stimulation by $\mathrm{CO}_{2}$ was related to nutrient limitations (Oren et al. 2001). In the replicated Duke Forest FACE experiment, Finzi et al.(Finzi et al. 2002) found that the demand for $\mathrm{N}$ by trees under $\mathrm{CO}_{2}$ enrichment exceeded the rate of $\mathrm{N}$ mineralization. These results suggest that we might expect a reduction in the stimulation of photosynthesis by elevated $\mathrm{CO}_{2}$ in the replicated Duke Forest FACE experiment after six years of treatment. The objective of this study was to examine the effects of elevated $\mathrm{CO}_{2}$ on the $A_{\text {sat }} N$ relationships through the canopy of the loblolly pine forest and to determine if the stimulatory effects of elevated $\mathrm{CO}_{2}$ on photosynthesis have been sustained at the Duke Forest FACE experiment. I hypothesized that the slope of the $A_{s a t} N$ relationship would be increased by $\mathrm{CO}_{2}$ enrichment, indicative of greater nitrogen use efficiency by the tree species grown under elevated $\mathrm{CO}_{2}$. Light-saturated photosynthetic rates $\left(A_{s a t}\right)$ and foliar $\mathrm{N}$ of two overstory and four understory tree species were measured at their growth $\mathrm{CO}_{2}$ concentrations during the early summer and late summer of 1999 , 2001, and 2002. In 2001 and 2002, $A_{\text {sat }} N$ relationships were compared at reciprocal $\mathrm{CO}_{2}$ concentrations to determine if the stimulatory effects of elevated $\mathrm{CO}_{2}$ had been reduced. I hypothesized that reduced foliar $\mathrm{N}$ in plants grown with elevated $\mathrm{CO}_{2}$ would lead to a shift in the origin of the $A_{\text {sat }}-N$ relationship when the relationships of the ambient and elevated $\mathrm{CO}_{2}$ treatments were compared at similar $\mathrm{CO}_{2}$ concentrations. However, a reduction in the stimulation of photosynthesis by elevated $\mathrm{CO}_{2}$ without a concurrent loss of foliar $\mathrm{N}$ would lead to a reduction in the y-intercept of the $A_{\text {sat }} N$ relationship for plants grown in elevated $\mathrm{CO}_{2}$. 


\section{Materials and Methods}

\section{Duke Forest Free-Air $\mathrm{CO}_{2}$ Enrichment (FACE) Experiment}

The Duke Forest FACE experiment is located in the Blackwood division of Duke Forest $\left(35^{\circ} 97^{\prime} \mathrm{N}, 79^{\circ} 09^{\prime} \mathrm{W}\right.$ ) in a loblolly pine (Pinus taeda L.) plantation planted in 1983 after the forest was clear-cut in 1979. Although this forest is a plantation, it has had no management measures to prevent the growth of other tree species. Loblolly pine dominates the overstory, but there is a significant number of sweetgum trees (Liquidambar styraciflua L.) growing into the overstory and approximately 50 other woody species located mostly in the forest understory. The forest is growing on nutrient-poor, clay-rich Alfisols of the Enon series that is typical of many upland areas in the southeastern United States.

Six $30 \mathrm{~m}$ diameter experimental rings were established within the forest. Three of these rings are ambient controls and three are replicate elevated $\mathrm{CO}_{2}$ treatments. Each FACE ring consists of 32 pipes that extend from the forest floor through the canopy and deliver a controlled amount of $\mathrm{CO}_{2}$ throughout the elevated rings with a target concentration of ambient $+200 \mu \mathrm{I} \mathrm{I}^{1}$. The three ambient control rings are equipped with blowers to deliver the same volume of air to the control rings to replicate any micrometeorological effects on the forest that occurs during operation. From August 1996 through the period of this study (summer 2002), the forest received $24 \mathrm{~h} \mathrm{~d}^{-1} \mathrm{CO}_{2}$ fumigation except on days when the air temperature was below $5^{\circ} \mathrm{C}$ for more than one hour. During the first five years of the experiment (1997-2002), the daytime mean $\mathrm{CO}_{2}$ concentration of the elevated rings was $572 \mu 1 \mathrm{I}^{1}$ and the ambient rings was $376 \mu 1 \mathrm{I}^{1}$. For a detailed description of the Duke Forest FACE experiment see Hendrey et al. (Hendrey et al. 1999). 


\section{Gas Exchange and Leaf Chemistry}

Three overstory loblolly pine, two overstory sweetgum trees, and three trees from each of four species growing in the understory (sweetgum, redbud (Cercis canadensis L.), pignut hickory (Carya glabra Miller), and red maple (Acer rubrum L.) were selected in each FACE ring. Light-saturated net photosynthetic rates were measured at the growth $\mathrm{CO}_{2}$ concentration ( $A_{\text {sat }}, 380$ or $580 \mu \mathrm{I} \mathrm{I}^{-1} \mathrm{CO}_{2}$ ) on current year needles of loblolly pine and fully-expanded leaves of hardwood species during early summer (June-July) and late summer (August-September) of 1999, 2001, and 2002 with an open flow infrared gas analyzer equipped with an attached redblue light source (LI-6400, LI-COR, Lincoln, NE USA). Measurements were made with 1400 $\mu \mathrm{mol} \mathrm{m} \mathrm{m}^{-2}$ photosynthetic photon flux density (PPFD) in the overstory and $400 ? \mathrm{~mol} \mathrm{~m}^{-2} \mathrm{~s}^{-1}$ PPFD in the understory. During the late summer measurement period of 2001 and both measurement periods of 2002, light-saturated net photosynthetic rates were also measured at the reciprocal growth $\mathrm{CO}_{2}$ concentrations, either $380 \mu 1 \mathrm{I}^{1} \mathrm{CO}_{2}\left(A_{380}\right)$ or $580 ? 1 \mathrm{I}^{1} \mathrm{CO}_{2}\left(A_{580}\right)$. Photosynthesis was recorded when leaves had reached steady-state conditions with saturating light intensity. Needles and leaves of overstory loblolly pine and sweetgum trees were measured in upper (full sun), middle, and lower (shade) regions of the canopy. Measurements were made between $1000 \mathrm{~h}$ and $1600 \mathrm{~h}$ on sunny days in order to minimize diurnal effects. Minimum air temperatures during the sample period ranged from 13 to $19^{\circ} \mathrm{C}$ and maximum temperatures ranged from 30 to $34^{\circ} \mathrm{C}$. During the 1999 and 2001 sample periods soil moisture averaged $\sim 21 \%$ (Schafer et al. 2002). However, 2002 was much drier as the soil moisture during the two sample periods averaged only $\sim 15 \%$ (H. Kim, unpublished data). 
After gas exchange measurements were completed, each leaf was harvested and assayed for total $\mathrm{N}$ on a mass basis $\left([\mathrm{N}]_{\mathrm{m}}\right)$ and on a leaf area basis $\left([\mathrm{N}]_{\mathrm{a}}\right)$. Leaf tissue for $\mathrm{N}$ analysis was dried at $65^{\circ} \mathrm{C}$ and measured with a $\mathrm{CN}$ autoanalyzer (CE Instruments, Milan, Italy). Leaf mass per unit area $\left(\mathrm{LM}_{\mathrm{a}}, \mathrm{g} \mathrm{m}^{-2}\right)$ was calculated as the ratio of leaf dry mass to photosynthetic surface area.

\section{Statistical Analysis}

Leaf-level morphological and physiological measurements were analyzed for each species separately in this study. The two overstory species were tested individually for statistical significance using a four-way analysis of variance $($ ANOVA, $?=0.05)$ with growth $\mathrm{CO}_{2}$ concentration $\left(\mathrm{CO}_{2}\right)$, canopy position, season, and year as the main effects. For leaf-level analyses, canopy position included only the upper (full sun) and lower (shade) measurements. In the understory, leaf- level measurements were analyzed using a three-way ANOVA $(?=0.05)$ for each species. The main effects in the understory statistical model were $\mathrm{CO}_{2}$ concentration, season, and year and these effects were considered fixed.

$A_{\text {sat }}-N$ relationships for each measurement date and an $A_{\text {sat }}-N$ relationship across all measurement dates were calculated using photosynthesis and foliar $\mathrm{N}$ measured on a leaf area basis from all six tree species using least squares linear regression analysis. Heterogeneity of slopes of these relationships due to growth $\mathrm{CO}_{2}$ concentration $\left(C_{a}\right)$ or measurement date (D) was examined using an analysis of covariance $(?=0.05)$ with foliar $\mathrm{N}\left([\mathrm{N}]_{\mathrm{a}}\right)$ concentration as the covariate, where a significant $\mathrm{CO}_{2} \times[\mathrm{N}]_{\mathrm{a}}$ interaction would indicate a significant difference in the slope of the $A_{s a t}-N$ relationships, and provide evidence for adjustment in the photosynthetic nitrogen use efficiency of elevated $\mathrm{CO} 2$-grown trees. Alternatively, a significant difference in 
the main effect of $\mathrm{CO}_{2}$ concentration would simply indicate only an overall $\mathrm{CO}_{2}$ induced adjustment of photosynthesis that is unrelated to foliar $\mathrm{N}$ concentration. Furthermore, a significant $C_{a} \times[\mathrm{N}]_{\mathrm{a}} \times \mathrm{D}$ interaction would indicate that the effect of $\mathrm{CO}_{2}$ on the $A_{s a t}-N$ relationship was dependent upon measurement date.

In order to determine whether the stimulatory effects of elevated $\mathrm{CO}_{2}$ on photosynthesis had declined over time, $A_{\text {sat }} N$ relationships calculated at common $\mathrm{CO}_{2}$ concentration were analyzed using the same fixed and interactive effects as above Significant differences in the $\mathrm{CO}_{2}$ $\mathrm{x}[\mathrm{N}]_{\mathrm{a}}$ interactive effect would indicate a physiological adjustment in foliar $\mathrm{N}$ concentration that may impact the photosynthetic response to $\mathrm{CO}_{2}$ enrichment. A significant difference in the main effect of $\mathrm{CO}_{2}$ concentration (y-intercept of the relationship) would indicate a loss of photosynthetic capacity without a reduction or adjustment in foliar $\mathrm{N}$ concentration.

\section{Results}

\section{Net Photosynthesis}

Averaged across all measurements periods, elevated $\mathrm{CO}_{2}$ strongly stimulated lightsaturated net photosynthesis $\left(\mathrm{A}_{\text {sat }}\right)$ of loblolly pine $(44 \%, P<0.0001$, Table 2.1$)$ and sweetgum trees $(40 \%, P=0.005$, Table 2.1$)$ across both canopy positions in the forest overstory of the Duke Forest FACE experiment. $\mathrm{A}_{\text {sat }}$ of both overstory species was significantly higher in sun leaves than in shade leaves and the stimulation of photosynthesis for sweetgum trees by elevated $\mathrm{CO}_{2}$ depended upon the position of the leaf in the overstory canopy $(P=0.02)$. Elevated $\mathrm{CO}_{2}$ increased $\mathrm{A}_{\text {sat }}$ of sweetgum sun leaves approximately $60 \%$ whereas shade leaves were only stimulated by $37 \%$. In loblolly pine, there was only a statistical trend for a greater stimulation of $\mathrm{A}_{\text {sat }}$ by $\mathrm{CO}_{2}$ enrichment $(P=0.095)$. $\mathrm{A}_{\text {sat }}$ of loblolly pine sun needles was stimulated $48 \%$ by 
elevated $\mathrm{CO}_{2}$ compared to a $27 \%$ stimulation of $\mathrm{A}_{\text {sat }}$ in shade needles. For both loblolly pine and sweetgum, $\mathrm{A}_{\text {sat }}$ varied season to season (pine, $\mathrm{P}<0.0001$; sweetgum, $\mathrm{P}=0.0247$ ) and year to year (pine, $P=0.0049$; sweetgum, $P=0.025$ ) but the stimulation of $\mathrm{A}_{\text {sat }}$ by elevated $\mathrm{CO}_{2}$ did not vary due to year or month in either species (Table 2.1).

In the Duke forest FACE understory $\mathrm{A}_{\text {sat }}$ was stimulated by elevated $\mathrm{CO}_{2}$ in all four species measured (Table 2.2). The greatest stimulation of $\mathrm{A}_{\text {sat }}$ by $\mathrm{CO}_{2}$ enrichment in the understory was for redbud leaves $(61 \%, P=0.02)$ and the least stimulation was for red maple leaves $(24 \%, P=0.049)$. $\mathrm{A}_{\text {sat }}$ of understory hickory and sweetgum leaves was stimulated by $50 \%$ and $44 \%$, respectively, with $\mathrm{CO}_{2}$ enrichment. The stimulation of $\mathrm{A}_{\text {sat }}$ by elevated $\mathrm{CO}_{2}$ did not vary with season or year in any of the four understory species measured.

\section{Leaf Morphology and Chemistry}

Elevated $\mathrm{CO}_{2}$ did not significantly affect foliar $\mathrm{N}$ concentrations of loblolly pine needles or sweetgum leaves in the sun or the shade canopy positions during any sample period of this study (Table 2.3). In addition, elevated $\mathrm{CO}_{2}$ had no effect on leaf mass per unit area $\left(\mathrm{LM}_{\mathrm{a}}\right)$ of these two species in the forest overstory. In the understory, $\mathrm{LM}_{\mathrm{a}}$ was increased by $\mathrm{CO}_{2}$ enrichment in all species except for hickory (Table 2.4). The largest stimulation of $\mathrm{LM}_{\mathrm{a}}$ by elevated $\mathrm{CO}_{2}$ was only $12 \%$ and was observed in understory-grown sweetgum trees. However, neither mass nor area based foliar $\mathrm{N}$ concentrations varied between ambient and elevated $\mathrm{CO}_{2}$ in any of the understory species examined in this study.

Foliar $\mathrm{N}$ concentrations on a mass basis of overstory loblolly pine and sweetgum trees were not affected by canopy position. In both species, however, $\mathrm{LM}_{\mathrm{a}}$ was greater in sun leaves than in shade leaves and, as a result, $\mathrm{N}_{\mathrm{a}}$ of overstory loblolly pine and sweetgum trees showed 
similar differences in the upper and lower canopy. Sun needles of loblolly pine trees had $41 \%$ greater $\mathrm{LM}_{\mathrm{a}}(P<0.0001)$ and $58 \% \mathrm{~N}_{\mathrm{a}}(P<0.0001)$ than shade needles when averaged across all seasons and years (Table 2.3). For overstory sweetgum trees, sun leaves of had 65\% greater $\mathrm{LM}_{a}$ $(P=0.017)$ and $84 \%$ greater $\mathrm{N}_{\mathrm{a}}(P<0.001)$ than shade leaves when averaged across all measurement periods (Table 2.3).

In all of the understory species, $\mathrm{LM}_{\mathrm{a}}$ and $\mathrm{N}_{\mathrm{a}}$ increased between early summer and late summer in all species (Table 2.4 ). On the other hand, $[\mathrm{N}]_{\mathrm{m}}$ of all species except understory sweetgum decreased between early summer and late summer during the years 1999 and 2001 (Table 2.4). In 2002, no seasonal change in $\mathrm{N}_{\mathrm{m}}$ was observed for any of the species.

Net Photosynthesis-Nitrogen Relationships

$A_{\text {sat }} N$ relationships were developed by regressing light-saturated net photosynthesis measured at the growth $\mathrm{CO}_{2}$ concentrations on foliar $\mathrm{N}$ concentration, using the two most dominant tree species in the forest overstory as well as the four tree species in the understory found in the greatest abundance in the ambient and elevated $\mathrm{CO}_{2} \mathrm{FACE}$ rings. Elevated $\mathrm{CO}_{2}$ stimulated the $A_{\text {sat }} N$ relationship at each measurement date in 1999, 2001, and 2002 and the stimulation of the $A_{\text {sat }} N$ relationship by elevated $\mathrm{CO}_{2}$ was not significantly altered by season or year of measurement (Table 2.5, Figure 2.1). Elevated $\mathrm{CO}_{2}$ increased the slope of the $A_{\text {sat }} \mathrm{N}$ relationships by approximately $81 \%\left(\mathrm{CO}_{2} \times \mathrm{N}, P=0.005\right)$ when calculated across all species and measurement dates (Table 2.5, Figure 2.2).

The slope of the $A_{\text {sat }} N$ relationships of ambient and elevated $\mathrm{CO}_{2}$-grown plants measured at common $\mathrm{CO}_{2}$ concentrations were not significantly different when either $380 ? 1 \mathrm{I}^{1}(P=0.556)$ or 580 ? $1 \mathrm{I}^{1} \mathrm{CO}_{2}\left(P=0.887\right.$; Table 2.6) were used as common $\mathrm{CO}_{2}$ concentrations (Figure 2.3). I 
also found no significant changes in the $\mathrm{y}$-intercepts of ambient or elevated $\mathrm{CO}_{2}$-grown trees when relationships were determined at $380 ? 1 \mathrm{I}^{1}(P=0.214)$ or $580 ? 1 \mathrm{I}^{-1}(P=0.551) \quad$ These results were consistent across all measurement dates $\left(\mathrm{CO}_{2} \times \mathrm{D} ; \mathrm{P}=0.76\right)$.

\section{Discussion}

Leaf-level photosynthesis of overstory and understory tree species in the Duke Forest FACE experiment was stimulated by $\mathrm{CO}_{2}$ enrichment, but a large amount of variation in this response was found across species and canopy position. Photosynthesis was especially responsive to foliar $\mathrm{N}_{\mathrm{a}}$ with greater $\mathrm{CO}_{2}$ enhancement at higher $\mathrm{N}_{\mathrm{a}}$ and, as a result, elevated $\mathrm{CO}_{2}$ increased the slope of the $A_{\text {sat }} N$ relationship by $81 \%$ when averaged across all sample dates (Figure 2.2). This increase by elevated $\mathrm{CO}_{2}$ is remarkably close to the $74 \%$ increase in slope of the $A_{\text {sat }}-N$ relationship found by a meta-analysis of 10 studies examining the responses of pine and hardwood trees grown with $\mathrm{CO}_{2}$ enrichment (Peterson et al. (1999), Furthermore, Takeuchi et al. (2001) found that the slope of the $A_{\text {sat }} N$ relationship through the canopy of Populus tremuloides was increased $59 \%$ by elevated $\mathrm{CO}_{2}$. The increase in slope of the $A_{\text {sat }}-N$ relationship of elevated $\mathrm{CO}_{2}$-grown trees indicates an increase in photosynthetic nitrogen- use efficiency (PNUE) since there was a strong enhancement of leaf level photosynthesis but no reduction in leaf $\mathrm{N}$ by $\mathrm{CO}_{2}$ enrichment. However, the increase in slope of the $A_{s a t}-N$ relationship by elevated $\mathrm{CO}_{2}$ also indicates that the stimulation in PNUE is not constant and reflects differential effects of $\mathrm{CO}_{2}$ on photosynthesis in the sun and shade portions of the forest canopy.

Model estimates predict an increase in forest productivity with elevated $\mathrm{CO}_{2}$. However, this increase relies on a sustained stimulation of photosynthesis by elevated $\mathrm{CO}_{2}$ (Reynolds et al. 1996). This study using two overstory and five understory tree species clearly shows a sustained 
positive response of photosynthesis to elevated $\mathrm{CO}_{2}$ after 6 years of treatment in the Duke Forest FACE experiment. I found very little change in the $\mathrm{CO}_{2}$ stimulation of photosynthesis across season or year despite the year 2002 being one of the driest summers on record for piedmont North Carolina (Waple and Lawrimore 2002). Furthermore, the effect of $\mathrm{CO}_{2}$ on photosynthesis of loblolly pine needles growing at the top of the canopy was very similar in magnitude to the $\mathrm{CO}_{2}$ enhancement of photosynthesis measured during the first year of $\mathrm{CO}_{2}$ treatment (Myers et al. 1999). Also, the percent stimulation of photosynthesis by elevated $\mathrm{CO}_{2}$ for sun and shade sweetgum leaves was comparable to the stimulation of photosynthesis in overstory sweetgum trees averaged across the first three years of the Duke Forest FACE experiment (Herrick and Thomas 1999).

In order to further determine whether the stimulatory effect of elevated $\mathrm{CO}_{2}$ on photosynthesis had been reduced over time, I compared the long term response to $\mathrm{CO}_{2}$ to an immediate change in $\mathrm{CO}_{2}$ concentration by examining $A_{\max }-N$ relationships in the elevated and ambient rings at common $\mathrm{CO}_{2}$ levels (Curtis et al. 2000). Reductions in the $\mathrm{CO}_{2}$ response of photosynthesis are often associated with a nearly proportional reduction in foliar $\mathrm{N}$ (Curtis and Wang 1998) and, thus I hypothesized that reduced foliar $\mathrm{N}$ in plants grown with elevated $\mathrm{CO}_{2}$ would lead to a shift in the origin of the $A_{s a t} N$ relationship when the relationships of the ambient and elevated $\mathrm{CO}_{2}$ treatments were compared at similar $\mathrm{CO}_{2}$ concentrations. If, however, there was a reduction in the stimulatory effect of elevated $\mathrm{CO}_{2}$ on photosynthesis without a concurrent loss of foliar $\mathrm{N}$, as has been observed in senescing loblolly pine needles (Rogers and Ellsworth 2002), I expected a reduction in the y-intercept of the $A_{\text {sat }} N$ relationship for plants grown in elevated $\mathrm{CO}_{2}$. I found that neither the slope nor the y-intercept of the $A_{s a t}-N$ relationships of ambient and elevated $\mathrm{CO}_{2}$ rings measured at common $\mathrm{CO}_{2}$ concentrations were affected by 
growth $\mathrm{CO}_{2}$ concentration at any of the three sample periods (Figure 2.3). I also found no evidence of a shift in the origin of the $A_{\text {sat }}-N$ relationships of ambient and elevated $\mathrm{CO}_{2}$ rings since I observed no $\mathrm{CO}_{2}$-induced decline of foliar nitrogen in the overstory or understory tree species (Tables 2.3 and 2.4). Many of the tree species in the understory and sweetgum in the overstory had foliar $\mathrm{N}$ concentrations above values that are typically found in $\mathrm{N}$-limiting conditions (Blinn and Buckner 1989). The exception to this was during the strong sustained drought of 2002 when the concentrations of foliar N of every species in the Duke Forest FACE experiment were low. On the other hand, the concentration of foliar $\mathrm{N}$ in loblolly pine needles at all measurement periods were close to those values where $\mathrm{N}$ begins to limit loblolly pine productivity (<11 $\mathrm{mg} \mathrm{g}^{-1}$, (Allen 1987)). Interestingly, with the exception of 2002, the values of $[\mathrm{N}]_{\mathrm{m}}$ and $[\mathrm{N}]_{\mathrm{a}}$ in overstory and understory tree species that I observed were very similar to those that have been reported in earlier studies performed at the Duke Forest FACE experiment (Herrick and Thomas 1999, Myers et al. 1999, DeLucia and Thomas 2000, Rogers and Ellsworth 2002), indicating that foliar $\mathrm{N}$ of these species have changed very little over the six years of this experiment.

In conclusion, I found no $\mathrm{CO}_{2}$-induced changes in foliar nitrogen concentration nor loss of stimulation of photosynthesis in two overstory and four understory tree species in the Duke Forest FACE experiment after six years of $\mathrm{CO}_{2}$ enrichment. By using $A_{\text {sat }}-N$ relationships, I incorporated a large amount of variation associated with a complex forest stand, including light and foliar $\mathrm{N}$ gradients, seasonal effects, and different species, into the photosynthetic responses to $\mathrm{CO}_{2}$ and scaling net photosynthesis to leaf $\mathrm{N}$ has the additional benefit in that process-based models use this fundamental relationship to predict carbon flux in forest ecosystems (Aber and Federer 1992, Aber et al. 1996) . The increase in slope of the $A_{s a t}-N$ relationships of elevated 
$\mathrm{CO}_{2}$-grown trees implies a large increase in photosynthetic nitrogen-use efficiency and may contribute to an increase in nitrogen use efficiency to at the ecosystem level, as has been found at the Duke Forest FACE experiment (Finzi et al. 2002). These relationships between foliar N and photosynthesis indicate that the photosynthetic responses of forest trees to elevated atmospheric $\mathrm{CO}_{2}$ may be significantly altered by changes in $\mathrm{N}$ availability brought about by increased demand for $\mathrm{N}$ with growth under elevated $\mathrm{CO}_{2}$. 


\section{References}

Aber, J., P. Reich and M. Goulden 1996. Extrapolating leaf $\mathrm{CO}_{2}$ exchange to the canopy: a generalized model of forest photosynthesis compared with measurements by eddy correlation. Oecologia. 106:257-265.

Aber, J.D. and A. Federer 1992. A generalized, lumped-parameter model of photosynthesis, evapotranspiration and net primary production in temperate and boreal forest ecosystems. Oecologia. 92:463-474.

Allen, H.L. 1987. Forest fertilizers. Journal of Forestry. 85:37-46.

Blinn, C.R. and E.R. Buckner 1989. Normal foliar nutrient levels in North American forest trees: A summary. University of Minnesota, Minnesota Agricultural Experiment Station, St. Paul, MN.

Bowes, G. 1993. Facing the inevitable: plants and increasing atmospheric $\mathrm{CO}_{2}$. Annu. Rev. Plant Physiol. Plant Mol. Biol.:309-332.

Curtis, P., C. Vogel, X. Wang, K. Pregitzer, D. Zak, J. Lussenhop, M. Kubiske and J. Teeri 2000. Gas exchange, Leaf nitrogen, and growth efficiency of populus tremuloides in a $\mathrm{CO}_{2-}$ enriched atmosphere. Ecological Applications. 10:3-17.

Curtis, P. and X. Wang 1998. A meta-analysis of elevated $\mathrm{CO}_{2}$ effects on woody plant mass, form, and physiology. Oecologia. 113:299-313.

Curtis, P.S., C.S. Vogel, K.S. Pregitzer, D.R. Zak and J.A. Teeri 1995. Interacting effects of soil fertility and atmospheric $\mathrm{CO}_{2}$ on leaf area growth and carbon gain physiology in Populus X euramericana (Dode) Guinier. New phytologist. 129:253-263.

DeLucia, E.H. and R.B. Thomas 2000. Photosynthetic responses to $\mathrm{CO}_{2}$ enrichment of four hardwood species in a forest understory. Oecologia. 122:11-19.

El Kohen, A. and M. Mousseau 1994. Interactive effects of elevated $\mathrm{CO}_{2}$ and mineral nutrition on growth and $\mathrm{CO}_{2}$ exchange of sweet chestnut seedlings (Castanea sativa). Tree Physiology. 14:679-690.

Evans, J. 1989. Photosynthesis and Nitrogen relationships in leaves of C3 plants. Oecologia. 78:9-19.

Farquhar, G.D. and T.D. Sharkey 1982. Stomatal conductance and photosynthesis. Annual Review of Plant Physiology. 33:317-345. 
Field, C. and H.A. Mooney 1986. The photosynthesis-nitrogen relationship in wild plants. In On the Economy of Plant Form and Function Ed. T.J. Givnish. Cambridge University Press, Cambridge, UK, pp. 25-55.

Finzi, A.C., E.H. DeLucia, J.G. Hamilton, D.D. Richter and W.H. Schlesinger 2002. The nitrogen budget of a pine forest under free air $\mathrm{CO}_{2}$ enrichment. Oecologia. 132:567-578.

Gunderson, C. and S. Wullschleger 1994. Photosynthic Acclimation in trees to rising atmospheric $\mathrm{CO}_{2}$ : a broader perspective. Photosynthesis Research. 39:369-388.

Gunderson, C.A., J.D. Sholtis, S.D. Wullschleger, D.T. Tissue, P.J. Hanson and R.J. Norby 2002. Environmental and stomatal control of photosynthetic enhancement in the canopy of a sweetgum (Liquidambar styraciflua L.) plantation during 3 years of $\mathrm{CO}_{2}$ enrichment. Plant Cell and Environment. 25:379-393.

Hendrey, G.R., D.S. Ellsworth, K.F. Lewin and J. Nagy 1999. A free-air enrichment system for exposing tall forest vegetation to elevated atmospheric $\mathrm{CO}_{2}$. Global Change Biology. 5:293-309.

Herrick, J.D. and R.B. Thomas 2001. No photosynthic down-regulation in sweet gum trees (Liquidambar styraciflua L.) after 3 yrs. of $\mathrm{CO}_{2}$ enrichment at the Duke forest face experiment. Plant Cell and Environment. 24:53-64.

Herrick, J.D. and R.B. Thomas 1999. Effects of $\mathrm{CO}_{2}$ enrichment on the photosynthetic light response of sun and shade leaves of canopy sweetgum trees (Liquidambar styraciflua) in a forest ecosystem. Tree Physiology. 19:779-786.

Ingestad, T. and V. Stoy 1982. Mineral nutrition of wheat (Triticum aestivum cultivar Prins), rye (Secale cereale), barley (Hordeum vulgare cultivar Ingrid) and oat (Avena sativa cultivar Sol II) seedlings in nutrient solutions. Swedish Journal of Agricultural Research. 12:185192.

Kubiske, M., D. Zak, K. Pregitzer and Y. Takeuchi 2002. Photosynthesis acclimation of overstory Populus tremuloides and understory Acer saccharum to elevated atmospheric $\mathrm{CO}_{2}$ concentration: interactions with shade and soil nitrogen. Tree Physiology. 22:321329.

Long, S.P. and B.G. Drake 1991. Effect of long-term elevation of $\mathrm{CO}_{2}$ concentration in the field on the quantum yield of photosynthesis of the $\mathrm{C}_{3}$ sedge, Scirpus olneyi. Plant Physiology. 96:221-226.

Medlyn, B.E., F.W. Badeck, D.G.G. de Pury, C.V.M. Barton, M. Broadmeadow, R. Ceulemans, P. De Angelis, M. Forstreuter, M.E. Jach and S. Kellomaki 1999. Effects of elevated $\left[\mathrm{CO}_{2}\right]$ on photosynthesis in European forest species: a meta-analysis of model parameters. Plant Cell and Environment. 22:1475-1495. 
Myers, D.A., R.B. Thomas and E.H. DeLucia 1999. Photosynthetic capacity of loblolly pine (Pinus taeda L.) trees during the first year of carbon dioxide enrichment in a forest ecosystem. Plant Cell and Environment. 22:473-481.

Norby, R.J., S.D. Wullschleger, C.A. Gunderson, D.W. Johnson and R. Ceulemans 1999. Tree responses to rising $\mathrm{CO} 2$ in field experiments: implications for the future forest. Plant, Cell, and Environment. 22:683-714.

Oren, R., D.S. Ellsworth, K.H. Johnsen, N. Phillips, B.E. Ewers, C. Maier, K.V.R. Schafer, H. McCarthy, G. Hendrey, S.G. McNulty and G.G. Katul 2001. Soil fertility limits carbon sequestration by forest ecosystems in a $\mathrm{CO}_{2}$-enriched atmosphere. Nature. 411:469-472.

Peterson, A. and CMEAL participants 1999. Reconciling the apparent differences between massand area-based expressions of the photosynthesis-nitrogen relationships. Oecologia. 118:144-150.

Peterson, A., Y. Luo, C. Field and CMEAL Participants 1999. The photosynthesis- leaf nitrogen relationships at ambient and elevated atmospheric carbon dioxide: a meta-analysis. Global Change Biology. 5:331-346.

Piatek, K. and H.L. Allen 2000. Site preparation effects on foliar N and P use, retranslocation, and transfer to litter in 15-year old Pinus taeda. Forest Ecology and Management. 129:143-152.

Radoglou, K.M., P. Aphalo and P.G. Jarvis 1992. Response of photosynthesis, stomatal conductance and water use efficiency to elevated $\mathrm{CO}_{2}$ and nutrient supply in acclimated seedlings of Phaseolus vulgaris L. Annals of Botany. 70:257-264.

Reich, P.B., M.B. Walters and D.E. Ellsworth 1997. From tropics to tundra: global convergence in plant functioning. Proceedings of the National Academy of Sciences. 94:13730-13734.

Reynolds, J.F., P.R. Kemp, B. Acock, J. Chen and D.L. Moorehead 1996. Progress, limitations, and challenges in modeling the effects of elevated $\mathrm{CO}_{2}$ on plants and ecosystems. In Carbon Dioxide and Terrestrial Ecosystems Eds. G.W. Koch and H.A. Mooney. Academic Press, San Diego, USA, pp. 347-379.

Richter, D.D., D. Markewitz, P.R. Heine, V. Jin, J. Raikes, K. Tian and C.G. Wells 2000. Legacies of agriculture and forest regrowth in the nitrogen of old-field soils. Forest Ecology and Management. 138:233-248.

Rogers, A. and D.S. Ellsworth 2002. Photosynthetic acclimation of Pinus taeda (loblolly pine) to long-term growth in elevated $p \mathrm{CO}_{2}$ (FACE). Plant Cell and Environment. 25:851-858.

Sage, R.F. 1994. Acclimation of photosynthesis to increasing atmospheric $\mathrm{CO}_{2}$ : the gas exchange perspective. Photosynthesis Research. 39:741-762. 
Schafer, K.V.R., R. Oren, C. Lai and G.G. Katul 2002. Hydrologic balance in an intact temperate forest ecosystem under ambient and elevated atmospheric $\mathrm{CO}_{2}$ concentration. Global Change Biology. 8

Sharkey, T.D. 1985. Photosynthesis in intact leaves of $\mathrm{C}_{3}$ plants: physics, physiology and rate limitations. Botany Review. 51

Stitt, M. 1991. Rising $\mathrm{CO}_{2}$ levels and their potential significance for carbon flow in photosynthetic cells. Plant, Cell, and Environment. 14:741-762.

Takeuchi, Y., M.E. Kubiske, J.G. Isebrands, K.S. Pregtizer, G. Hendrey and D.F. Karnosky 2001. Photosynthesis, light and nitrogen relationships in a young deciduous forest canopy under open-air $\mathrm{CO}_{2}$ enrichment. Plant, Cell, and Environment. 24:1257-1268.

Terashima, I. and J.R. Evans 1988. Effects of light and nitrogen nutrition on the organization of the photosynthetic apparatus in spinach. Plant and Cell Physiology. 29:143-155.

Tissue, D.T., R.B. Thomas and B.R. Strain 1993. Long-term effects of elevated $\mathrm{CO}_{2}$ and nutrients on photosynthesis and rubisco in loblolly pine seedlings. Plant, Cell, and Environment. 16:859-865.

Vitousek, P.M. and R.W. Howarth 1991. Nitrogen limitation on land and in the sea: How can it occur? Biogeochemistry. 13:87-115.

von Caemmerer, S. and G.D. Farquhar 1981. Some relationships between biochemistry of photosynthesis and gas exchange of leaves. Planta. 153:376-387.

Waple, A.M. and J.H. Lawrimore 2002. State of the Climate. American Meteorological Society, p. 68. 
Figure Legends:

-27 - 
Table 2.1. Light-saturated net photosynthesis of needles and leaves located at the top (sun) and bottom (shade) of P.taeda (PITA) and L. styraciflua (LIST) growing in the overstory at the Duke Forest FACE experiment under ambient (AMB) and elevated (ELV) $\mathrm{CO}_{2}$. Each value is the mean of three treatment rings for both loblolly pine and sweetgum $( \pm 1 \mathrm{SE})$ measured at the growth $\mathrm{CO}_{2}$ concentration in the early and late summers of 1999, 2001, and 2002.

\begin{tabular}{|c|c|c|c|c|c|}
\hline & & & & \multicolumn{2}{|c|}{$A_{\text {sat }}$} \\
\hline & & & & AMB & ELV \\
\hline \multirow[t]{12}{*}{ PITA } & \multirow[t]{6}{*}{ Sun } & \multirow[t]{2}{*}{1999} & Early & $4.4(0.5)$ & $8.5(0.8)$ \\
\hline & & & Late & $5.4(0.4)$ & $8.0(0.4)$ \\
\hline & & \multirow[t]{2}{*}{2001} & Early & $7.9(0.9)$ & $10.5(0.6)$ \\
\hline & & & Late & 6.3(0.6) & $10.9(1.4)$ \\
\hline & & \multirow[t]{2}{*}{2002} & Early & $5.9(0.9)$ & $7.8(1.0)$ \\
\hline & & & Late & $7.7(1.3)$ & $9.8(0.4)$ \\
\hline & \multirow[t]{6}{*}{ Shade } & \multirow[t]{2}{*}{1999} & Early & $4.3(0.6)$ & $5.5(0.8)$ \\
\hline & & & Late & $4.0(1.3)$ & $5.7(0.3)$ \\
\hline & & \multirow[t]{2}{*}{2001} & Early & 7.1(1.6) & $8.3(0.8)$ \\
\hline & & & Late & $5.6(0.8)$ & 7.1(1.1) \\
\hline & & \multirow[t]{2}{*}{2002} & Early & $3.9(0.4)$ & $5.6(0.5)$ \\
\hline & & & Late & $5.9(0.7)$ & $6.8(0.4)$ \\
\hline \multirow[t]{12}{*}{ LIST } & \multirow[t]{6}{*}{ Sun } & \multirow[t]{2}{*}{1999} & Early & $11.0(0.7)$ & $18.4(2.7)$ \\
\hline & & & Late & $10.1(0.3)$ & $14.8(2.7)$ \\
\hline & & \multirow[t]{2}{*}{2001} & Early & $10.4(0.8)$ & $15.0(1.2)$ \\
\hline & & & Late & $9.0(1.2)$ & $14.9(2.8)$ \\
\hline & & \multirow[t]{2}{*}{2002} & Early & $6.1(0.1)$ & $11.6(2.5)$ \\
\hline & & & Late & 7.8(0.3) & $12.3(5.4)$ \\
\hline & \multirow[t]{6}{*}{ Shade } & \multirow[t]{2}{*}{1999} & Early & $6.4(0.6)$ & $7.2(0.2)$ \\
\hline & & & Late & $4.6(0.7)$ & $5.5(0.3)$ \\
\hline & & \multirow[t]{2}{*}{2001} & Early & 7.4(0.6) & $7.7(0.8)$ \\
\hline & & & Late & $4.2(0.6)$ & 7.1(0.5) \\
\hline & & \multirow[t]{2}{*}{2002} & Early & $3.1(0.5)$ & $6.2(1.4)$ \\
\hline & & & Late & $2.4(0.2)$ & $4.9(0.3)$ \\
\hline
\end{tabular}


Table 2.2. Light-saturated net photosynthesis understory A. rubrum (ACRU), C. glabra (CAGL), C. canadensis (CECA), and L. styraciflua (LIST) growing in the understory at the Duke Forest FACE experiment under ambient (AMB) and elevated (ELV) $\mathrm{CO}_{2}$. Each value is the mean of three treatment rings $( \pm 1 \mathrm{SE})$ measured at the growth $\mathrm{CO}_{2}$ concentration in the early and late summers of 1999, 2001, and 2002.

\begin{tabular}{lclcc} 
& & & \multicolumn{2}{c}{$A_{\text {sat }}$} \\
& & & AMB & ELV \\
\hline ACRU & 1999 & Early & $4.4(0.4)$ & $6.0(0.7)$ \\
& & Late & $3.2(0.5)$ & $5.1(0.4)$ \\
& 2001 & Early & $4.6(0.9)$ & $6.0(0.7)$ \\
& & Late & $6.2(1.7)$ & $5.1(0.7)$ \\
& 2002 & Early & $3.4(0.1)$ & $4.5(0.3)$ \\
& & Late & $3.0(0.3)$ & $4.1(2.2)$ \\
CAGL & 1999 & Early & $4.7(0.4)$ & $6.4(0.2)$ \\
& & Late & $2.7(0.6)$ & $4.7(0.3)$ \\
& 2001 & Early & $4.6(0.4)$ & $5.4(1.1)$ \\
& & Late & $3.0(0.9)$ & $4.4(1.2)$ \\
& 2002 & Early & $3.4(0.2)$ & $4.4(0.1)$ \\
& & Late & $2.7(0.6)$ & $4.7(0.3)$ \\
CECA & 1999 & Early & $11.0(0.7)$ & $18.4(2.7)$ \\
& & Late & $10.1(0.3)$ & $14.8(2.7)$ \\
& 2001 & Early & $15.0(1.2)$ & $10.4(0.8)$ \\
& & Late & $9.0(1.2)$ & $14.9(2.8)$ \\
& 2002 & Early & $6.1(0.1)$ & $11.6(2.5)$ \\
& & Late & $7.8(0.3)$ & $12.3(5.4)$ \\
LIST & 1999 & Early & $6.4(0.6)$ & $7.2(0.2)$ \\
& & Late & $4.6(0.7)$ & $5.5(0.3)$ \\
& 2001 & Early & $7.4(0.6)$ & $7.7(0.8)$ \\
& & Late & $4.2(0.6)$ & $7.1(0.5)$ \\
& 2002 & Early & $3.1(0.5)$ & $6.2(1.4)$ \\
& & Late & $2.4(0.2)$ & $4.9(0.3)$
\end{tabular}


Table 2.3. Leaf mass per unit area (LMa), mass-based foliar $\mathrm{N}$ concentration $([\mathrm{N}] \mathrm{m})$ and area based foliar $\mathrm{N}$ concentration $\left([\mathrm{N}]_{\mathrm{a}}\right)$ at the top and bottom of the canopy of loblolly pine (PITA) and sweetgum (LIST) trees growing in the forest overstory of the Duke Forest FACE experiment. Measurements were made twice each year (early and late summer) during 1999, 2001, and 2002 in both ambient (AMB) and elevated (ELV) $\mathrm{CO}_{2}$ plots. Each value is the mean of three treatment plots $( \pm 1 \mathrm{SE})$.

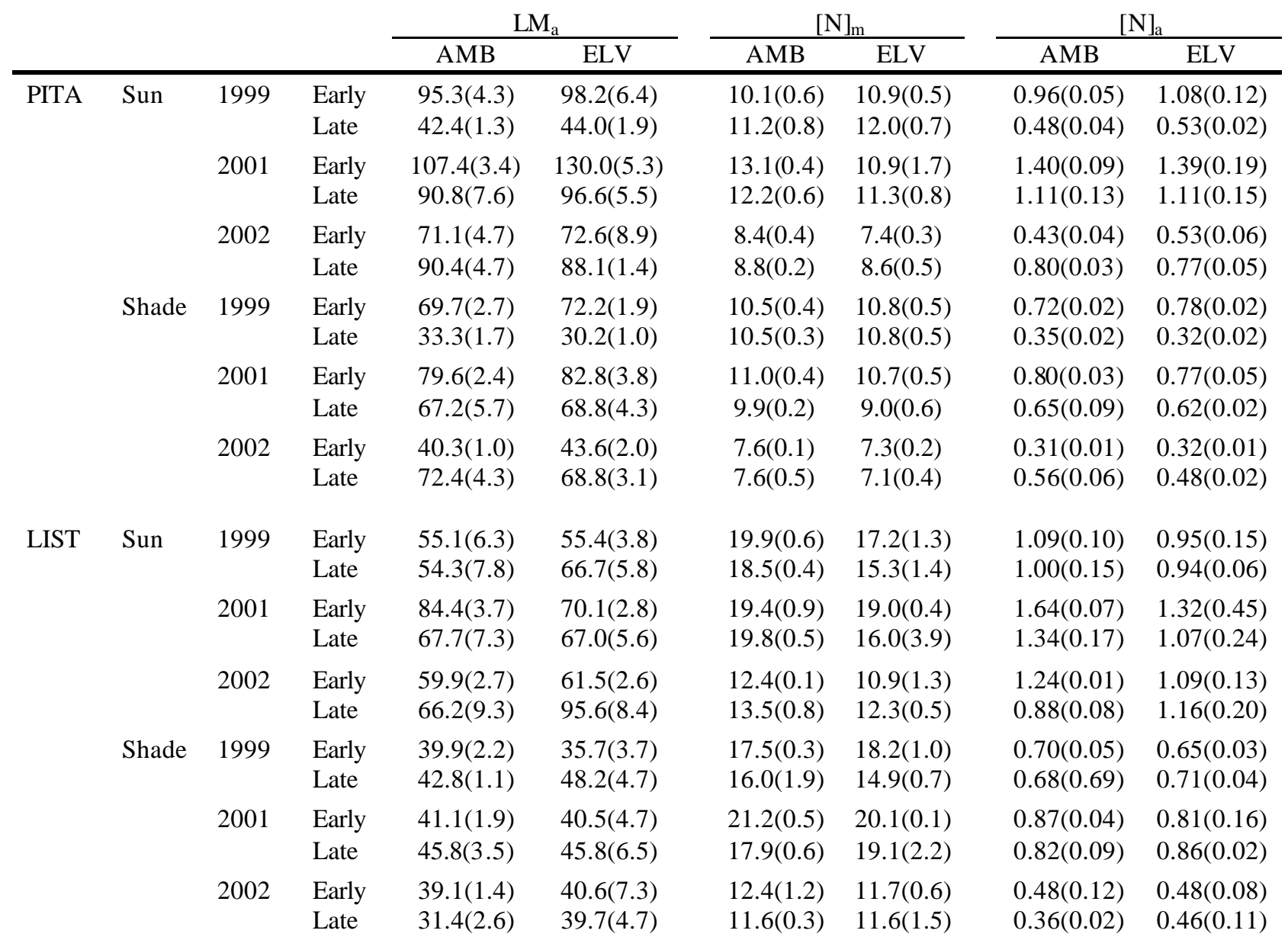


Table 2.4. Leaf mass per unit area $\left(\mathrm{LM}_{\mathrm{a}}\right)$, mass-based foliar $\mathrm{N}$ concentrations $([\mathrm{N}] \mathrm{m})$ and area based foliar $\mathrm{N}$ concentration ([N]a) of red maple (ACRU), hickory (CAGL), redbud (CECA), and sweetgum (LIST) trees growing in the forest understory of the Duke Forest FACE experiment. Measurements were made twice each year (early and late summer) during 1999, 2001, and 2002 in both ambient (AMB) and elevated (ELV) $\mathrm{CO}_{2}$ plots. Each value is the mean of three treatment plots $( \pm 1 \mathrm{SE})$.

\begin{tabular}{|c|c|c|c|c|c|c|c|c|}
\hline & & & \multicolumn{2}{|c|}{$\mathrm{LM}_{\mathrm{a}}$} & \multicolumn{2}{|c|}{$[\mathrm{N}]_{\mathrm{m}}$} & \multicolumn{2}{|c|}{$[\mathrm{N}]_{\mathrm{a}}$} \\
\hline & & & $\mathrm{AMB}$ & ELV & AMB & ELV & AMB & ELV \\
\hline \multirow[t]{6}{*}{ ACRU } & 1999 & Early & $32.7(1.9)$ & $34.1(2.0)$ & $22(1.8)$ & $19.0(0.6)$ & $0.71(0.03)$ & $0.65(0.04)$ \\
\hline & & Late & $40.6(3.9)$ & $44.0(2.4)$ & $15.4(0.2)$ & $16.1(0.5)$ & $0.62(0.09)$ & $0.70(0.02)$ \\
\hline & 2001 & Early & $33.7(3.6)$ & $34.9(4.1)$ & $20.8(1.3)$ & $17.5(0.4)$ & $0.71(0.11)$ & $0.62(0.09)$ \\
\hline & & Late & $36.7(2.4)$ & $40.8(2.8)$ & $13.7(0.5)$ & $16.9(5.3)$ & $0.70(0.04)$ & $0.86(0.26)$ \\
\hline & 2002 & Early & $30.9(0.5)$ & $35.2(2.9)$ & $12.2(0.3)$ & $12.5(0.6)$ & $0.38(0.01)$ & $0.44(0.05)$ \\
\hline & & Late & $48.1(4.1)$ & $58.4(1.6)$ & $12.0(1.2)$ & $12.0(1.5)$ & $0.58(0.02)$ & $0.70(0.01)$ \\
\hline \multirow[t]{6}{*}{ CAGL } & 1999 & Early & $32.8(3.2)$ & $34.0(0.4)$ & $20.0(1.5)$ & $19.7(0.8)$ & $0.65(0.05)$ & $0.66(0.02)$ \\
\hline & & Late & $40.3(1.5)$ & $43.9(2.1)$ & $17.0(0.5)$ & $16.4(0.9)$ & $0.68(0.01)$ & $0.72(0.05)$ \\
\hline & 2001 & Early & $31.3(2.1)$ & $33.3(2.0)$ & $20.6(0.8)$ & $18.4(0.6)$ & $0.64(0.09)$ & $0.61(0.03)$ \\
\hline & & Late & $34.4(2.6)$ & $30.1(5.7)$ & $14.8(1.2)$ & $15.7(3.5)$ & $0.84(0.04)$ & $0.70(0.12)$ \\
\hline & 2002 & Early & $32.6(1.7)$ & $33.7(0.4)$ & $13.8(0.4)$ & 13.3(0.6) & $0.45(0.03)$ & $0.45(0.02)$ \\
\hline & & Late & $53.1(9.1)$ & $44.2(3.1)$ & $18.0(0.3)$ & $15.0(0.2)$ & $0.92(0.15)$ & $0.64(0.09)$ \\
\hline \multirow[t]{6}{*}{ CECA } & 1999 & Early & $24.1(5.0)$ & $28.5(3.4)$ & $24.7(2.2)$ & 23.1(1.8) & $0.58(0.07)$ & $0.65(0.03)$ \\
\hline & & Late & $30.5(1.7)$ & $31.6(4.9)$ & 21.1(1.9) & $18.6(1.6)$ & $0.64(0.02)$ & $0.57(0.04)$ \\
\hline & 2001 & Early & $24.5(2.1)$ & $22.2(0.2)$ & $25.7(2.2)$ & $25.5(2.6)$ & $0.62(0.03)$ & $0.58(0.06)$ \\
\hline & & Late & $23.8(2.2)$ & $27.7(3.6)$ & $11.7(2.4)$ & $19.9(0.5)$ & $0.53(0.02)$ & $0.92(0.06)$ \\
\hline & 2002 & Early & $26.0(0.2)$ & $27.0(1.9)$ & 18.1(1.4) & $16.1(0.8)$ & $0.47(0.03)$ & $0.43(0.02)$ \\
\hline & & Late & $37.5(5.1)$ & $38.2(2.4)$ & $18.1(0.1)$ & $16.2(0.2)$ & $0.66(0.06)$ & $0.59(0.04)$ \\
\hline \multirow[t]{6}{*}{ LIST } & 1999 & Early & $26.4(3.5)$ & $34.5(2.9)$ & $20.8(1.2)$ & 20.1(0.9) & $0.55(0.08)$ & $0.70(0.07)$ \\
\hline & & Late & $32.7(2.6)$ & $37.3(2.5)$ & $17.8(0.9)$ & $17.3(0.9)$ & $0.57(0.04)$ & $0.64(0.05)$ \\
\hline & 2001 & Early & $28.7(2.3)$ & $30.9(1.8)$ & $15.9(3.1)$ & $15.2(3.1)$ & $0.48(0.10)$ & $0.58(0.14)$ \\
\hline & & Late & $26.9(6.3)$ & $30.2(1.2)$ & $15.8(3.7)$ & $15.5(3.9)$ & $0.55(0.15)$ & $0.76(0.09)$ \\
\hline & 2002 & Early & $25.9(1.6)$ & $27.4(6.5)$ & $13.7(0.8)$ & $13.3(0.2)$ & $0.35(0.03)$ & $0.44(0.06)$ \\
\hline & & Late & $38.3(2.6)$ & $40.9(3.0)$ & $15.0(0.9)$ & $15.6(1.2)$ & $0.57(0.04)$ & $0.64(0.08)$ \\
\hline
\end{tabular}


Table 2.5. Regression components of the $A_{s a t}-N$ relationships in the forest canopy of the Duke Forest FACE experiment measured during 1999, 2001, and 2002 in early and late summer.

\begin{tabular}{|c|c|c|c|c|c|}
\hline & & & Slope & $y$-intercept & $R^{2}$ \\
\hline \multirow[t]{4}{*}{1999} & Early & AMB & 8.71 & -0.99 & 0.69 \\
\hline & & & 12.66 & -2.12 & \\
\hline & Late & AMB & 7.22 & 0.02 & 0.62 \\
\hline & & ELV & 11.81 & -0.95 & 0.58 \\
\hline \multirow{4}{*}{2001} & Early & AMB & 4.00 & 2.47 & 0.58 \\
\hline & & ELV & 5.51 & 2.81 & 0.74 \\
\hline & Late & AMB & 4.91 & 1.08 & 0.58 \\
\hline & & ELV & 9.82 & -1.05 & 0.77 \\
\hline \multirow[t]{4}{*}{2002} & Early & AMB & 2.08 & 2.80 & 0.47 \\
\hline & & ELV & 4.70 & 3.12 & 0.50 \\
\hline & Late & AMB & 9.95 & -2.85 & 0.66 \\
\hline & & ELV & 9.99 & -1.46 & 0.57 \\
\hline \multirow[t]{2}{*}{ All Years } & All Dates & AMB & 4.59 & 1.36 & 0.52 \\
\hline & & ELV & 8.32 & 0.68 & 0.66 \\
\hline
\end{tabular}


Table 2.6. Regression components of $A_{s a t}-N$ relationships measured at two common $\mathrm{CO}_{2}$ concentrations in the forest canopy of the Duke Forest FACE experiment during 1999, 2001, and 2002 in early and late summer.

\begin{tabular}{|c|c|c|c|c|c|c|c|c|}
\hline & & & \multicolumn{3}{|c|}{$A_{380}$} & \multicolumn{3}{|c|}{$A_{580}$} \\
\hline & & & Slope & $y$-intercept & $R^{2}$ & Slope & $y$-intercept & $R^{2}$ \\
\hline \multirow[t]{2}{*}{2001} & Late & AMB & 4.54 & 1.08 & 0.56 & 5.98 & 2.46 & 0.54 \\
\hline & & ELV & 5.68 & 0.20 & 0.66 & 8.24 & 0.51 & 0.62 \\
\hline \multirow[t]{4}{*}{2002} & Early & $\mathrm{AMB}$ & 8.21 & -0.61 & 0.62 & 5.52 & 1.46 & 0.80 \\
\hline & & ELV & 3.19 & 1.60 & 0.68 & 5.47 & 1.60 & 0.68 \\
\hline & Late & AMB & 3.36 & 1.33 & 0.55 & 4.71 & 2.46 & 0.60 \\
\hline & & ELV & 5.24 & 0.27 & 0.78 & 8.29 & 0.00 & 0.80 \\
\hline
\end{tabular}


Figure 2.1. Light-saturated net photosynthetic rates $\left(A_{\text {sat }}\right)$ measured at the growth $\mathrm{CO}_{2}$ concentration versus foliar $\mathrm{N}$ concentrations $\left(\left[\mathrm{N}_{\mathrm{a}}\right]\right)$ of loblolly pine, sweetgum, red maple, hickory, and redbud grown under ambient $\mathrm{CO}_{2}$ (closed circles, solid line) and elevated $\mathrm{CO}_{2}$ (open circles, dashed line). Measurements were conducted in (a) early summer 1999, (b) late summer 1999, (c) early summer 2001, (d) late summer 2001, (e) early summer 2002, (f) late summer 2002. Regression equations of these relationships can be found in Table 2.5. 


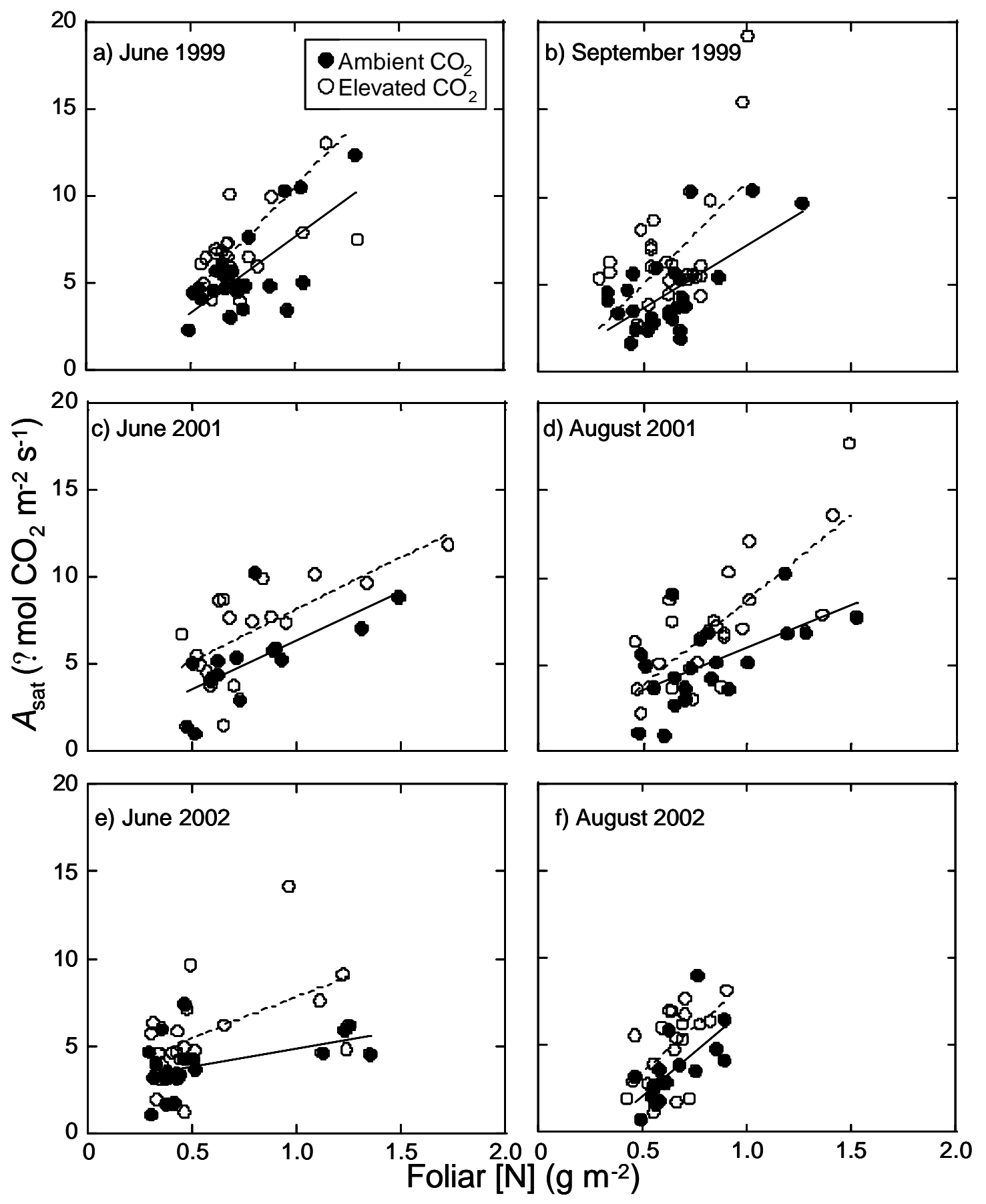


Figure 2.2. Light-saturated net photosynthetic rates $\left(A_{\text {sat }}\right)$ measured at the growth $\mathrm{CO}_{2}$ concentration versus foliar $\mathrm{N}$ concentrations $\left(\left[\mathrm{N}_{\mathrm{a}}\right]\right)$ of loblolly pine, sweetgum, red maple, hickory, and redbud grown under ambient $\mathrm{CO}_{2}$ (closed circles, solid line) and elevated $\mathrm{CO}_{2}$ (open circles, dashed line). Data were pooled to calculate a single relationship for each $\mathrm{CO}_{2}$ treatment across all measurement dates. Regression equations of these relationships can be found in Table 2.5. 


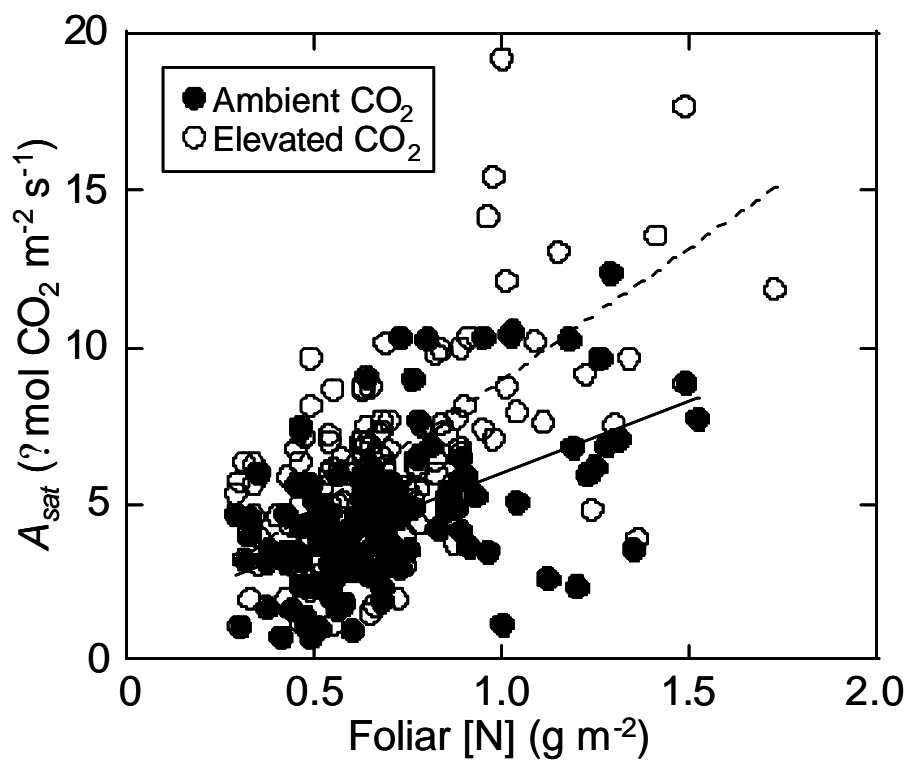


Figure 2.3. Light-saturated net photosynthetic rates $\left(A_{\text {sat }}\right)$ versus foliar $\mathrm{N}$ concentrations $\left(\left[\mathrm{N}_{\mathrm{a}}\right]\right)$ of loblolly pine, sweetgum, red maple, hickory, and redbud grown under ambient $\mathrm{CO}_{2}$ (closed circles, solid line) and elevated $\mathrm{CO}_{2}$ (open circles, dashed line). Measurements were made at two common $\mathrm{CO}_{2}$ concentrations of $380 ? 1 \mathrm{I}^{1} \mathrm{CO}_{2}\left(A_{380}\right)$ and $580 ? 1 \mathrm{I}^{1} \mathrm{CO}_{2}\left(A_{580}\right)$ during late summer 2001 (a,b) and early summer 2002 (c,d) and late summer 2002 (e,f). Regression equations of these relationships can be found in Table 2.6. 

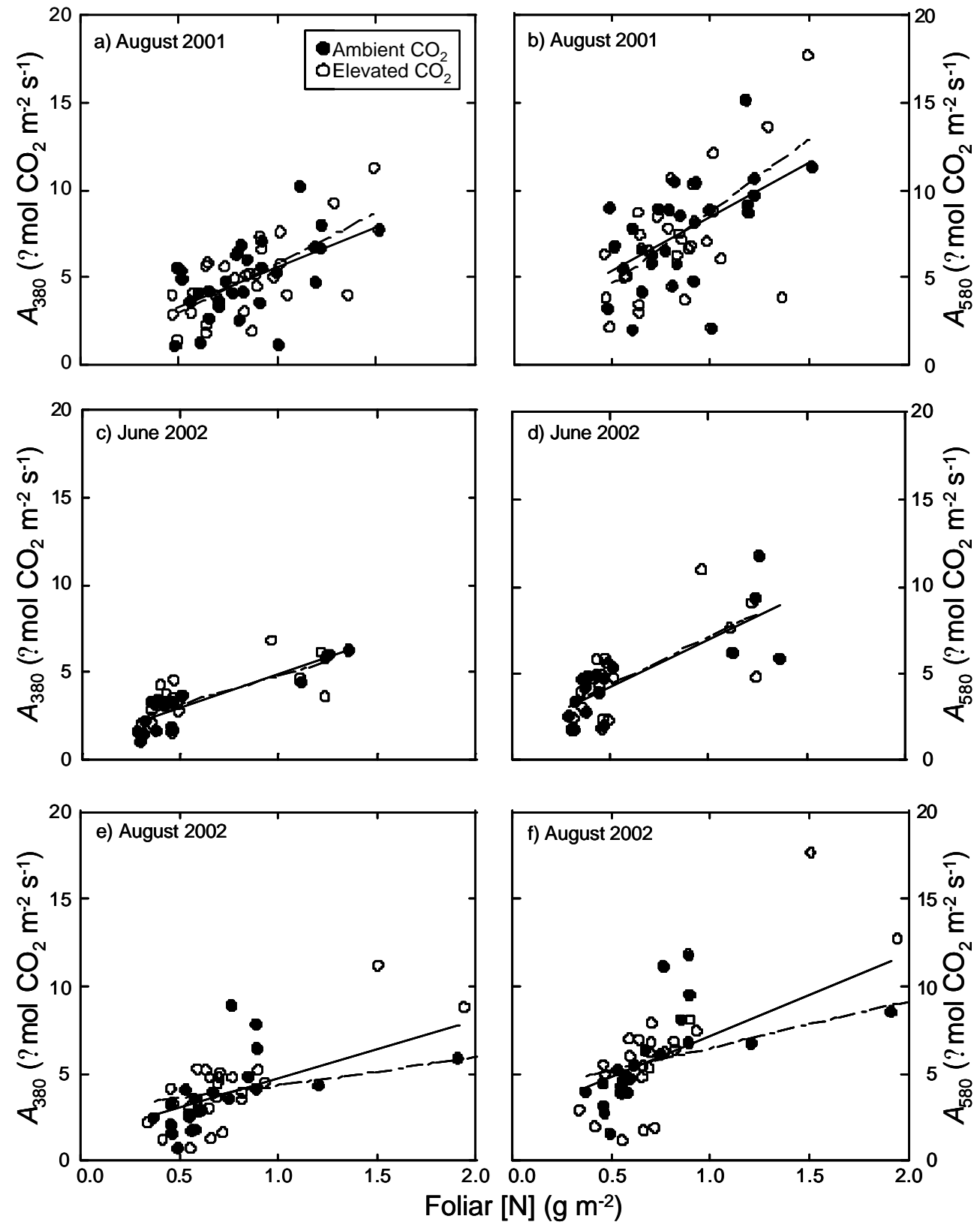
CHAPTER 3:

Photosynthetic responses of four understory tree species after 7 years of $\mathrm{CO}_{2}$ enrichment in the Duke Forest FACE experiment 


\begin{abstract}
In this study I examined the photosynthetic response of four species of saplings growing in the understory of the Duke Forest FACE experiment after seven years of $\mathrm{CO}_{2}$ enrichment. These same four species of saplings were measured in the first year of the Duke Forest FACE experiment and showed only seasonal fluctuations in acclimation of photosynthesis to elevated $\mathrm{CO}_{2}$. I hypothesized that after seven years of $\mathrm{CO}_{2}$ enrichment I would observe photosynthetic down-regulation in the saplings measured. I measured photosynthetic $\mathrm{CO}_{2}$-response and light response curves, along with chlorophyll fluorescence, chlorophyll concentration, and foliar $\mathrm{N}$ to diagnose potential elevated $\mathrm{CO}_{2}$-induced photosynthetic down-regulation twice during the summer of 2003. I found a continued stimulation of photosynthesis $\left(A_{\text {sat }}\right)$ by elevated $\mathrm{CO}_{2}$ in all four species measured. Elevated $\mathrm{CO}_{2}$ stimulated the electron transport efficiency $\left(J_{\max }\right)$ of two of the species measured but did not alter the carboxylation efficiency $\left(V c_{\max }\right)$. I found no effect of $\mathrm{CO}_{2}$ enrichment on quantum yield measured by light curves, chlorophyll fluorescence, chlorophyll concentration, or foliar nitrogen concentration. Elevated $\mathrm{CO}_{2}$ continues to stimulate photosynthesis in the understory of the Duke Forest FACE experiment after seven years of $\mathrm{CO}_{2}$ enrichment. I found that the stimulation of photosynthesis was primarily driven by a reduction in the carbon limitation imposed on low-light grown plants, where plants acclimated by increasing the electron transport efficiency of leaves. This study represents one of the first long-term comparisons of photosynthesis of understory trees growing in elevated $\mathrm{CO}_{2}$.
\end{abstract}




\section{Introduction}

Understory species experience a continuously changing, unpredictable light environment that can range from a small proportion of the incident solar radiation found at the top of the canopy to near direct sunlight (Chazdon and Pearcy 1991). Variability in the light environment in a forest understory typically limits the growth and photosynthesis of plant species more so than other environmental factors (Pearcy 1983, Denslow et al. 1990, Pacala et al. 1994, Kobe et al. 1995). Under low light conditions, understory leaves are light-limited and, when compared to sun leaves, shade leaves have excess capacity to fix carbon in the Calvin-Benson cycle because of an increased investment of foliar nitrogen in light harvesting processes rather than carbon fixation (Evans 1989). Understory species contribute a significant amount to the overall carbon balance of many forest ecosystems; any changes that may occur with increased atmospheric $\mathrm{CO}_{2}$ could have an impact on forest succession and on the role of forests in the global carbon cycle in the future.

Increases in atmospheric $\mathrm{CO}_{2}$ concentrations are likely to reduce carbon limitations and stimulate photosynthesis of understory species despite low light availability. Relatively few studies, however, have examined the photosynthetic responses of understory plant species to elevated $\mathrm{CO}_{2}$ and very few have investigated these responses in a natural forest ecosystem (Osborne et al. 1997, Winter and Virgo 1998, Hattenschwiler 2001). In a review of the effects of elevated $\mathrm{CO}_{2}$ on plants growing under non-optimal conditions, Poorter \& Soba (2001) concluded that an inadequate number of studies had been performed investigating the interactions of lowlight availability and elevated $\mathrm{CO}_{2}$ to make a general statement about the response of plants to elevated $\mathrm{CO}_{2}$ when growing in a light-limited environment. In forest understory species, most studies have observed increased photosynthesis and subsequent increases in biomass production 
under elevated $\mathrm{CO}_{2}$ (DeLucia and Thomas 2000, Naumburg and Ellsworth 2000, Hattenschwiler 2001, Poorter and Perez-Soba 2001).

Most studies investigating understory species responses to elevated $\mathrm{CO}_{2}$ have been performed over short time periods but, long-term responses of understory species are not well understood. Many long-term $\mathrm{CO}_{2}$ enrichment experiments report a time dependent decline in the photosynthetic response of plants to elevated $\mathrm{CO}_{2}$ often referred to as photosynthetic downregulation. This loss in photosynthetic enhancement by elevated $\mathrm{CO}_{2}$ is sometimes accompanied by reductions in foliar $\mathrm{N}$ concentration and ribulose bisphosphate carboxylase-oxygenase (rubisco) activity (Long and Drake 1991, Stitt 1991, Bowes 1993, Sage 1994, Norby et al. 1999). With increased atmospheric $\mathrm{CO}_{2}$ and subsequent increased plant growth rates comes the possibility of increased resource demands, especially $\mathrm{N}$, which may exhaust the available nutrients in the soil more rapidly than under current atmospheric $\mathrm{CO}_{2}$ (Ingestad and Stoy 1982). As less $\mathrm{N}$ is available for photosynthetic processes, photosynthetic down-regulation may occur. Many forest ecosystems are N-limited (Vitousek and Howarth 1991) and this type of photosynthetic down-regulation might be a common occurrence in forests, such as piedmont loblolly pine forests, that have a low soil N availability (Radoglou et al. 1992, Tissue et al. 1993, El Kohen and Mousseau 1994, Sage 1994, Curtis et al. 1995). For example, a loss in the growth enhancement by elevated $\mathrm{CO}_{2}$ in the Duke Forest FACE prototype ring was restored when $\mathrm{N}$ fertilizer additions were made to the plot (Oren et al. 2001). This suggests that photosynthetic down-regulation due to reduced foliar $\mathrm{N}$ may soon be observed in the fully-replicated Duke FACE study. Furthermore, future forest productivity models depend on the assumption of a sustained increase of photosynthesis by elevated $\mathrm{CO}_{2}$ (Reynolds et al. 1996) and a complete 
understanding of the photosynthetic response of not only overstory species to elevated $\mathrm{CO}_{2}$ but also the photosynthetic response of understory species as well.

During the first year of the Duke Forest FACE experiment, DeLucia \& Thomas (2000) examined the photosynthetic responses of four species of understory saplings to elevated $\mathrm{CO}_{2}$. Elevated $\mathrm{CO}_{2}$ stimulated photosynthesis of all species but a small degree of down-regulation of photosynthesis in the high $\mathrm{CO}_{2}$ treatment was observed. These results, however, were inconsistent; they varied seasonally and observations of photosynthetic down regulation were explained by a long period of severe drought during the growing season prior to the measurements (DeLucia \& Thomas, 2000). The current study re-examines the photosynthetic responses of the same four understory species (Acer rubrum, Carya glabra, Cercis canadensis, and Liquidambar styraciflua) after seven years of $\mathrm{CO}_{2}$ enrichment at the Duke Forest FACE experiment. These measurements were made during early and late summer of 2003, one of the wettest years on record in piedmont, NC and after a winter ice storm removed approximately $26 \%$ of the canopy leaf area. To understand the long-term response of photosynthesis in these understory species to elevated $\mathrm{CO}_{2}$, I measured photosynthetic light response curves, $\mathrm{CO}_{2}$ response curves and parameters associated with chlorophyll fluorescence and concentration on at two times during the seventh growing season under $\mathrm{CO}_{2}$ enrichment. I hypothesized that, as $\mathrm{N}$ becomes more limiting under elevated $\mathrm{CO}_{2}$ due to increased demand by elevated $\mathrm{CO}_{2}$-grown trees, I will observe photosynthetic-down regulation in the four species measured. I also hypothesized that increased light availability due to a loss in leaf area in the forest overstory that elevated $\mathrm{CO}_{2}$-grown saplings may exhibit an up-regulation of photosynthesis. 


\section{Materials and Methods}

\section{Site Description}

The Duke University FACE experiment is located in the Blackwood division of Duke Forest $\left(35^{\circ} 97^{\prime} \mathrm{N}, 7^{\circ} 09^{\prime} \mathrm{W}\right.$ ) in a loblolly pine (Pinus taeda L.) plantation that has undergone no management measurements since establishment in 1983. The site consists of six $30 \mathrm{~m}$ diameter experimental FACE rings established within the forest. Three of these rings deliver ambient + $200 \mu \mathrm{I}^{1} \mathrm{CO}_{2}$ during daylight hours to the portion of the loblolly pine forest within the ring. The remaining FACE rings serve as ambient experiment control rings, which are equipped to deliver the same volume of air as the treatment rings to replicate any micrometeorological effects on the forest that may occur during the operation of the FACE facility. Hendrey et al. (1999) provides a detailed description of the entire Duke Forest FACE experiment and its operational procedures. Since the beginning of $\mathrm{CO}_{2}$ fumigation (1997-2003), the daytime mean $\mathrm{CO}_{2}$ concentration of the elevated rings has been $576 \mu \mathrm{mol} \mathrm{mol}^{1}$ and in the ambient rings the daytime mean $\mathrm{CO}_{2}$ concentration has been $376 \mu \mathrm{mol} \mathrm{mol}^{-1}$. Saplings of the species Acer rubrum (ACRU), Carya glabra (CAGL), Cercis canadensis (CECA), and Liquidambar styraciflua (LIST) growing in the understory of Duke Forest FACE experiment were selected to perform a detailed analysis of the response of leaf gas exchange and fluorescence of understory tree species to elevated atmospheric $\mathrm{CO}_{2}$.

\section{Gas Exchange and Chlorophyll Fluorescence Measurements}

Photosynthetic-light response curves, photosynthetic- $\mathrm{CO}_{2}$ response curves and chlorophyll fluorescence were measured on leaves of four to six saplings of each species in two ambient and two elevated $\mathrm{CO}_{2}$ FACE rings in early June 2003 and early September 2003. Gas 
exchange measurements were made with an open-flow gas exchange system (LI-6400, LiCor Inc., USA) with an environmentally controlled cuvette. All gas exchange measurements were made between $1000 \mathrm{~h}$ and $1600 \mathrm{~h}$ (EST) on clear days. During gas exchange measurements neither leaf temperature, nor relative humidity significantly differed between the June $\left(\mathrm{T}_{\mathrm{air}}=24.8 \pm 0.6{ }^{\circ} \mathrm{C}, \mathrm{RH}=58.8 \pm 0.2 \%\right)$ and September $\left(\mathrm{T}_{\text {air }}=20.8 \pm 0.9^{\circ} \mathrm{C}, \mathrm{RH}=58.1 \pm 0.3 \%\right)$ measurement periods.

Photosynthesis measurements were recorded across nine incident irradiance levels between 0 and $1200 ? \mathrm{~mol} \mathrm{~m}^{-2} \mathrm{~s}^{-1}$ (photosynthetic-photon flux density, PPFD) on one fully expanded leaf per sapling and were used to calculate photosynthetic-light response curves. A red-blue LED light source $(?=650 \mathrm{~nm})$ attached to the LI-6400 supplied the incident irradiance. Cuvette $\mathrm{CO}_{2}$ concentrations were held at $380 \mu \mathrm{mol} \mathrm{mol}{ }^{-1} \mathrm{CO}_{2}$ for ambient grown saplings and $580 \mu \mathrm{mol} \mathrm{mol}{ }^{-1} \mathrm{CO}_{2}$ for elevated $\mathrm{CO}_{2}$-grown saplings. Apparent quantum efficiency $\left(Q_{\mathrm{e}}\right)$, respiration $\left(R_{\mathrm{d}}\right)$, light saturated maximum photosynthesis $\left(A_{\mathrm{sat}}\right)$, and light compensation point (?), were estimated from light response curves using the Photosynthesis Assistant software package (Dundee Scientific Ltd., UK), which employs the calculations of Prioul \& Chartier (Prioul and Chartier 1977).

The relationship between net photosynthesis $(A)$ and calculated intercellular $\mathrm{CO}_{2}$ concentration $\left(C_{\mathrm{i}}\right)$ was used to determine if acclimation of photosynthesis to elevated $\mathrm{CO}_{2}$ had occurred in the measured saplings. Photosynthesis was measured over 10 external concentrations of $\mathrm{CO}_{2}$ ranging between 50 and $1500 \mu 11^{1} \mathrm{CO}_{2}$. Measurements were made with a saturating light level of $1000 ? \mathrm{~mol} \mathrm{~m}^{-2} \mathrm{~s}^{-1}$ PPFD. $A-C_{\mathrm{i}}$ curves were analyzed with the twofactor leaf photosynthesis model of Farquhar et al. (Farquahar et al. 1980) with modifications by Harley et al. (Harley et al. 1992). Light-saturated carboxylation efficiency ( $\left.V c_{\max }\right)$ of ribulose- 
bisphosphate carboxylase oxygenase (rubisco) and the electron transport efficiency $\left(J_{\max }\right)$ were calculated using the assumptions of Wullschleger (Wullschleger 1993).

A pulse-modulated flourometer (PAM-2000, Walz, Germany) was used to measure the chlorophyll fluorescence of the upper surface of the same leaves used for gas exchange measurements. Attached leaves were turned over and dark adapted for approximately three minutes before exposure to a weak modulating light beam that allowed measurement of baseline fluorescence $\left(\mathrm{F}_{\mathrm{o}}\right)$. The leaves were then exposed to a $0.6 \mathrm{~s}$ flash of saturating light to measure maximal fluorescence yield $\left(\mathrm{F}_{\mathrm{m}}\right)$. The optimal efficiency of photosystem II $\left(\mathrm{PS}_{\mathrm{II}}, \mathrm{F}_{\mathrm{v}} / \mathrm{F}_{\mathrm{m}}\right)$ was then calculated as $\left(\mathrm{F}_{\mathrm{m}}-\mathrm{F}_{\mathrm{o}}\right) / \mathrm{F}_{\mathrm{m}}$. After determination of $\mathrm{F}_{\mathrm{v}} / \mathrm{F}_{\mathrm{m}}$, the same leaf was exposed to four intensities of light provided by an actinic light source ranging from 25 to $350 ? \mathrm{~mol} \mathrm{~m}^{-2} \mathrm{~s}^{-1} \mathrm{PPFD}$ in $60 \mathrm{~s} \mathrm{intervals.} \mathrm{After} \mathrm{each} \mathrm{level} \mathrm{of} \mathrm{light} \mathrm{intensity,} \mathrm{a} 0.6 \mathrm{~s}$ flash of saturating light was used to determine light-adapted maximum fluorescence yield $\left(\mathrm{F}_{\mathrm{m}}{ }^{\prime}\right)$. Between each measurement leaves were exposed to $0.6 \mathrm{~s}$ of far-red light to estimate light induced adjustments of baseline fluorescence $\left(\mathrm{F}_{\mathrm{o}}{ }^{\prime}\right)$. The quantum yield of $\mathrm{PS}_{\mathrm{II}}\left(\right.$ ? $\left.\mathrm{PS}_{\mathrm{II}}\right)$ was then estimated using $\left(\mathrm{F}_{\mathrm{m}}{ }^{\prime}-\mathrm{F}_{\mathrm{o}}{ }^{\prime}\right) / \mathrm{F}_{\mathrm{m}}$ ' derived from Schreiber et al. (Schreiber et al. 1998).

\section{Leaf Characteristics}

Leaves used for gas exchange measurements were harvested for determination of specific leaf area (SLA), foliar N concentration on a mass ([N] mass) and an area ([N] $\left.]_{\text {area }}\right)$ basis, and chlorophyll concentration on a mass $\left(\mathrm{Chl}_{\text {mass }}\right)$ and area $\left(\mathrm{Chl}_{\text {area }}\right)$ basis. The mass of oven dried

leaf disks of an area of $3.14 \mathrm{~cm}^{2}$ were used to calculate SLA. These disks were then ground and combusted with an elemental analyzer (NC 2500, CE Instruments, Milan, Italy) to determine 
foliar $\mathrm{N}$ concentration. Disks frozen at the time of collection were ground in liquid $\mathrm{N}$ and extracted with $80 \%$ aqueous acetone for chlorophyll measurement as in Porra et al. (1989).

\section{Statistics}

All gas exchange, chlorophyll fluorescence measurements, and measurements of leaf morphology, with the exception of FPS $_{\text {II }}$ data were analyzed using a three-way analysis of variance (ANOVA, ? $=0.05)$ with growth $\mathrm{CO}_{2}$ concentration $(\mathrm{C})$, measurement date $(\mathrm{D})$, and species (S) as the main effects and C X D, S X C, S X D, and C X D X S as the interactive effects. When necessary to agree with the assumptions of the ANOVA test, a log-transformation was performed to assure normality. The relationship between FPS $_{\text {II }}$ and PPFD were evaluated using least squares linear regression analysis for each species individually. Heterogeneity of slopes of these relationships due to growth $\mathrm{CO}_{2}$ concentration $(\mathrm{C})$ was examined using an analysis of co-variance $(?=0.05)$ with PPFD as the covariate, where a significant $\mathrm{C} \times \mathrm{PPFD}$ interaction indicated a significant difference in the slope of the ?PS $\mathrm{PII}_{\text {II }}$-PPFD relationship measured.

\section{Results}

Light Response Curves

Elevated $\mathrm{CO}_{2}$ stimulated light-saturated photosynthetic rates in all four species measured ( $P=0.0005$, Figures $3.1 \& 3.2$, Table 3.1). The largest stimulation of $A_{\text {sat }}(120 \%)$ was found in $A$. rubrum in June; however this stimulation decreased to $65 \%$ in September. C. canadensis also showed a decrease in the amount of stimulation of $A_{\text {sat }}$ by elevated $\mathrm{CO}_{2}$ from June to September, in which $A_{\text {sat }}$ was stimulated by $67 \%$ in June and only by $28 \%$ in September. However, the stimulation of $A_{\text {sat }}$ by elevated $\mathrm{CO}_{2}$ remained relatively constant throughout the summer for $C$. 
glabra (17-22\%) and L. styraciflua (41\%-52\%). $\quad A_{\text {sat }}$ also significantly declined $(P=0.0021)$ throughout the summer irrespective of species or $\mathrm{CO}_{2}$ treatment (Table 3.1). Neither the apparent quantum efficiency $\left(Q_{\mathrm{e}}\right)$, respiration $\left(R_{\mathrm{d}}\right)$, nor the light compensation point $(\mathrm{G})$ derived from the photosynthetic- light response curves differed significantly between ambient and elevated $\mathrm{CO}_{2}$ or date in any of the four species (Table 3.1).

$\mathrm{CO}_{2}$ Response Curves

Elevated $\mathrm{CO}_{2}$-grown saplings showed no differences in $V c_{\max }$ in June or September (Table 3.2). However, $V c_{\max }$ of all species except $C$. canadensis did decline from June to September in both ambient and elevated $\mathrm{CO}_{2}$. The $V c_{\max }$ of $A$. rubrum, $C$. glabra, and $L$. styraciflua declined the most (62-77\%) from June to September, with the $V c_{\max }$ of $C$. canadensis only declining $33 \%$ across the same time period (Table 3.2 ). $J_{\max }$ was significantly higher under elevated $\mathrm{CO}_{2}$ in A. rubrum $(P=0.04)$ and $C$. glabra $(P=0.02)$. C. glabra $(P=0.0005)$ and $L$. styraciflua $(P=0.0002)$ were the only species in which I observed a significant decrease in $J_{\max }$ from June to September (Table 3.2). I found no significant differences due to $\mathrm{CO}_{2}$ treatment or date in the ratio of $V c_{\max }$ to $J_{\max }$ (Table 3.2) in any of the saplings measured.

\section{Chlorophyll Fluorescence \& Concentration}

The $\mathrm{F}_{\mathrm{v}} / \mathrm{F}_{\mathrm{m}}$ of elevated $\mathrm{CO}_{2}$-grown saplings did not significantly differ from ambient $\mathrm{CO}_{2}$ grown saplings in June or September (Table 3.3). Also, the relationships between ?PS $\mathrm{PII}_{\text {II }}$ and PPFD did not significantly differ between $\mathrm{CO}_{2}$ treatments or dates, in any of the species measured (Figures $3.3 \&$ 3.4). Area-based chlorophyll concentrations did significantly increase from June to September in all species, except $C$. glabra (Table 3.3). I observed the largest increase (28\%) in $\mathrm{Chl}_{\text {area }}$ from June to September in L. styraciflua $(P=0.0045)$ with A. rubrum 
$(P=0.04)$ and $C$. canadensis $(\mathrm{P}=0.08)$ increasing approximately $21 \%$ each. Elevated $\mathrm{CO}_{2}$ did not significantly affect the area or mass-based chlorophyll concentration, or the chlorophyll $a$ to chlorophyll $b$ ratios of any of the four species measured (Table 3.3).

\section{Leaf Properties}

Elevated $\mathrm{CO}_{2}$ did not significantly alter SLA (Table 3.3) in any species. SLA did decrease slightly from early summer to late summer in all species measured except $L$. styraciflua where SLA slightly increased, however neither were statistically significant (Table 3.3). Elevated $\mathrm{CO}_{2}$ did not significantly alter $[\mathrm{N}]_{\text {mass }}$ or $[\mathrm{N}]_{\text {area }}$ in any species; however $[\mathrm{N}]_{\operatorname{mass}}$ did significantly decrease in all species from June to September (Table 3.3). The largest decrease in $[\mathrm{N}]_{\text {mass }}$ was observed in C. glabra $(22 \%, P=0.0001)$ and the smallest decrease in A. rubrum $(16 \%, P=0.0038)$. When expressed on an area basis foliar $\mathrm{N}$ concentration was not significantly different between ambient and elevated $\mathrm{CO}_{2}$ in June or September (Table 3.3).

\section{Discussion}

After seven years of $\mathrm{CO}_{2}$ enrichment the stimulation of photosynthesis by elevated $\mathrm{CO}_{2}$ of the four species of understory saplings measured was sustained (Table 3.1, Figures 3.1 \& 3.2) when compared to the results of DeLucia and Thomas (2000) performed in the first year of the

Duke FACE experiment. There was no evidence of photosynthetic down-regulation that might occur as a result of increased $\mathrm{N}$ limitation with growth in elevated $\mathrm{CO}_{2}$. This result is surprising because in many long-term elevated $\mathrm{CO}_{2}$ studies a loss in the enhancement of photosynthesis is observed (Curtis and Wang 1998). However, some studies have shown a sustained increase in the response of photosynthesis to long-term $\mathrm{CO}_{2}$ enrichment (Herrick and Thomas 2001). Another unexpected result of the current study is the change in species that had the greatest 
photosynthetic response to elevated $\mathrm{CO}_{2}$. DeLucia \& Thomas (DeLucia and Thomas 2000) found the greatest stimulation of photosynthesis in C. canadensis, whereas the largest stimulation of photosynthesis was found in A. rubrum during this study. Similarly, in another study, A. rubrum and L. styraciflua also showed a significant stimulation of photosynthesis by elevated $\mathrm{CO}_{2}$ in the understory of the Duke FACE experiment (Naumburg and Ellsworth 2000). One explanation for this variation may be the dry months prior to the study of DeLucia \& Thomas (DeLucia and Thomas 2000) before measurements were taken in 1997 and the relatively wet months prior to the measurement period of this study in 2003. Another possible explanation was the occurrence of a large ice storm which destroyed approximately $26 \%$ of the Pinus taeda canopy at the Duke FACE experiment in the winter of 2002. This disturbance event may have increased light availability enough to decrease the light-limitation of photosynthesis of the understory trees and possibly increased the available $\mathrm{N}$ through the increase in leaf litter during the winter of 2002. As in the previous study, I found that elevated $\mathrm{CO}_{2}$ stimulated photosynthesis the most near saturating irradiances and if the loss in canopy mass increased the occurrence of direct sunlight reaching the understory this may be a partial explanation for the shift in species response observed from 1997 to 2003. As in DeLucia \& Thomas (2000), I found no $\mathrm{CO}_{2}$-induced differences in $Q_{\mathrm{e}}$ or ? $\mathrm{PS}_{\mathrm{II}}$ in any of the species measured.

I observed no significant changes in the $V c_{\max }$ of any of the elevated $\mathrm{CO}_{2}$-grown saplings in June or September. $V c_{\max }$ did significantly decrease 33 to $77 \%$ from June to September in all species irrespective of growth $\mathrm{CO}_{2}$ concentration (Table 3.2). This decrease in $V c_{\max }$ can be attributed to a decrease in foliar $\mathrm{N}$ concentration from June to September (Table 3.3). DeLucia \& Thomas (2000) found no difference in $V c_{\max }$ in June between $\mathrm{CO}_{2}$ treatments, but did find a significant decrease in $V c_{\max }$ in September. This observed change in $V c_{\max }$ was attributed to the 
persistence of a severe drought during the summer of 1997 at the Duke FACE experiment, which may have induced fall senescence earlier than in the current study. Our results also contrast those found in shade leaves of A. saccharum and P. tremuloides, where photosynthetic acclimation occurred and coincided with a decrease in $V c_{\max }$ and foliar $\mathrm{N}$ concentration (Takeuchi et al. 2001, Kubiske et al. 2002).

In the current study $J_{\max }$ significantly increased under elevated $\mathrm{CO}_{2}$ in each species (Table 3.2), with the increase ranging from 18 to 33\%. A. rubrum showed the largest increase at $33 \%$, this increase in electron transport efficiency coincides with A. rubrum yielding the largest observed stimulation of $A_{\text {sat }}$ by elevated $\mathrm{CO}_{2}$. Similarly, DeLucia \& Thomas (2000) also observed a stimulation of $J_{\max }$ by elevated $\mathrm{CO}_{2}$, however this stimulation was only $13 \%$ across all of the species measured. The increase in $J_{\max }$ observed in the earlier study caused an overall $10 \%$ increase in the ratio of $V c_{\max }$ to $J_{\max }$. However, in our study, because $V c_{\max }$ slightly increased and $J_{\max }$ significantly increased under elevated $\mathrm{CO}_{2}$, I observed no changes in the ratio of $V c_{\max }$ to $J_{\max }$. Despite the higher electron transport efficiency of elevated $\mathrm{CO}_{2}$-grown saplings, I found no differences in $F_{v} / F_{m}$ for any of the four species measured indicating no differences in the efficiency of $\mathrm{PS}_{\mathrm{II}}$. Elevated $\mathrm{CO}_{2}$ also did not significantly alter the concentration of chlorophyll in any of the saplings measured, but chlorophyll concentration did decrease from June to September in all species measured (Table 3.3).

I observed a sustained stimulation of the photosynthesis of A. rubrum, C. glabra, C. canadensis, and L. styraciflua growing in the understory of the Duke Forest FACE experiment after seven years of $\mathrm{CO}_{2}$ enrichment. Relieving the carbon limitation imposed on shade plants by increasing the atmospheric $\mathrm{CO}_{2}$ concentration primarily controlled this stimulation of photosynthesis. As in DeLucia \& Thomas (2000), I observed the greatest stimulation in species 
that showed an acclimatory response of the efficiency of ribulose-bisphophate regeneration.

However, these species were not the same species that showed the similar response in the year following initiation of $\mathrm{CO}_{2}$ enrichment at the Duke FACE experiment. 


\section{References}

Bowes, G. 1993. Facing the inevitable: plants and increasing atmospheric $\mathrm{CO}_{2}$. Annu. Rev. Plant Physiol. Plant Mol. Biol. 309-332.

Chazdon, R.L. and R.W. Pearcy 1991. The importance of sunflecks for forest understory plants. Bioscience. 41:760-766.

Curtis, P, Wang, X. 1998. A meta-analysis of elevated $\mathrm{CO}_{2}$ effects on woody plant mass, form, and physiology. Oecologia 113: 299-313.

Curtis, PS, Vogel, CS, Pregitzer, KS, Zak, DR, Teeri, JA. 1995. Interacting effects of soil fertility and atmospheric $\mathrm{CO}_{2}$ on leaf area growth and carbon gain physiology in Populus $X$ euramericana (Dode) Guinier. New Phytologist 129: 253-263.

DeLucia, EH, Thomas, RB. 2000. Photosynthetic responses to $\mathrm{CO}_{2}$ enrichment of four hardwood species in a forest understory. Oecologia 122: 11-19.

Denslow, JS, Schultz, JC, Vitousek, PM, Strain, BR. 1990. Growth responses of tropical shrubs to treefall gap environments. Ecology 71: 165-179.

El Kohen, A, Mousseau, M. 1994. Interactive effects of elevated $\mathrm{CO}_{2}$ and mineral nutrition on growth and $\mathrm{CO}_{2}$ exchange of sweet chestnut seedlings (Castanea sativa). Tree Physiology 14: 679-690.

Evans, J. 1989. Photosynthesis and Nitrogen relationships in leaves of C3 plants. Oecologia 78: 9-19.

Farquahar, GD, von Caemmerer, S, Berry, JA. 1980. A biochemical model of photosynthetic $\mathrm{CO}_{2}$ fixation in $\mathrm{C}_{3}$ species. Planta 149: 178-190.

Harley, PC, Thomas, RB, Reynolds, JF, Strain, BR. 1992. Modeling photosynthesis of cotton grown in elevated $\mathrm{CO}_{2}$. Plant, Cell and Environment 271-282.

Hattenschwiler, S. 2001. Tree seedling growth in natural deep shade: Functional traits related to interspecific variation in response to elevated $\mathrm{CO}_{2}$. Oecologia 129: 31-42.

Hendrey, G.R., D.S. Ellsworth, K.F. Lewin and J. Nagy 1999. A free-air enrichment system for exposing tall forest vegetation to elevated atmospheric $\mathrm{CO}_{2}$. Global Change Biology. 5:293-309.

Herrick, J, Thomas, R. 2001. No photosynthic down-regulation in sweet gum trees (Liquidambar styraciflua L.) after 3 yrs. of $\mathrm{CO}_{2}$ enrichment at the Duke forest face experiment. Plant Cell and Environment 24: 53-64. 
Ingestad, T, Stoy, V. 1982. Mineral nutrition of wheat (Triticum aestivum cultivar Prins), rye (Secale cereale), barley (Hordeum vulgare cultivar Ingrid) and oat (Avena sativa cultivar Sol II) seedlings in nutrient solutions. Swedish Journal of Agricultural Research 12: 185192.

Kobe, RK, Pacala, SW, Silander, JA, Canham, CD. 1995. Juvenile tree survivorship as a component of shade tolerance. Ecological Applications 5:

Kubiske, M, Zak, D, Pregitzer, K, Takeuchi, Y. 2002. Photosynthesis acclimation of overstory Populus tremuloides and understory Acer saccharum to elevated atmospheric $\mathrm{CO}_{2}$ concentration: interactions with shade and soil nitrogen. Tree Physiology 22: 321-329.

Long, SP, Drake, BG. 1991. Effect of long-term elevation of $\mathrm{CO}_{2}$ concentration in the field on the quantum yield of photosynthesis of the $\mathrm{C}_{3}$ sedge, Scirpus olneyi. Plant Physiology 96: 221-226.

Naumburg, E, Ellsworth, DS. 2000. Photosynthetic sunfleck utilization potential of understory saplings growing under elevated CO2 in FACE. Oecologia 122: 163-174.

Norby, RJ, Wullschleger, SD, Gunderson, CA, Johnson, DW, Ceulemans, R. 1999. Tree responses to rising $\mathrm{CO} 2$ in field experiments: implications for the future forest. Plant, Cell , and Environment 22: 683-714.

Oren, R, Ellsworth, DS, Johnsen, KH, Phillips, N, Ewers, BE, Maier, C, Schafer, KVR, McCarthy, H, Hendrey, G, McNulty, SG, Katul, GG. 2001. Soil fertility limits carbon sequestration by forest ecosystems in a $\mathrm{CO}_{2}$-enriched atmosphere. Nature 411: 469-472.

Osborne, C, Drake, B, LaRoche, J, Long, S. 1997. Does Long-term evelation of CO2 concetraction increase photosynthesis in forest floor vegetation. Plant Physiol. 114: 337344.

Pacala, SW, Canham, CD, Silander, JA, Kobe, RK. 1994. Sapling growth as a function of resources in a northern temperate forest. Canadian Journal of Forest Research 24: 2172 2183.

Pearcy, RW. 1983. The light environment and growth of $\mathrm{C}_{3}$ and $\mathrm{C}_{4}$ tree species in the understorey of a Hawaiian forest. Oecologia 58: 19-25.

Poorter, H, Perez-Soba, M. 2001. The growth response of plants to elevated $\mathrm{CO}_{2}$ under nonoptimal environmental conditions. Oecologia 129: 1-20.

Porra, RJ, Thompson, WA, Kriedemann, PE. 1989. Determination of accurate extinction coefficients and simultaneous equations for assaying chlorophylls a and b extracted with four different solvents:verification of the concentration of chlorophyll standards by atomic absorption spectroscopy. Biochimica et Biophysica Acta 975: 384-394. 
Prioul, JL, Chartier, P. 1977. Partitioning of transfer and carboxylation components of intracellular resistance to photosynthetic $\mathrm{CO}_{2}$ fixation: A critical analysis of the methods used. Annals of Botany 41: 789-800.

Radoglou, KM, Aphalo, P, Jarvis, PG. 1992. Response of photosynthesis, stomatal conductance and water use efficiency to elevated $\mathrm{CO}_{2}$ and nutrient supply in acclimated seedlings of Phaseolus vulgaris L. Annals of Botany 70: 257-264.

Reynolds, JF, Kemp, PR, Acock, B, Chen, J, Moorehead, DL. 1996. Progress, limitations, and challenges in modeling the effects of elevated $\mathrm{CO}_{2}$ on plants and ecosystems. In: Koch, GW, Mooney, HA, eds. Carbon Dioxide and Terrestrial Ecosystems. San Diego, USA: Academic Press, 347-379.

Sage, RF. 1994. Acclimation of photosynthesis to inc reasing atmospheric $\mathrm{CO}_{2}$ : the gas exchange perspective. Photosynthesis Research 39: 741-762.

Schreiber, U, Bilger, W, Hormann, H, Neubauer, C. 1998. Chlorophyll fluorescence as a diagnostic tool: basics and some aspects of practical relevance. In: Raghavendra, AS, eds. Photosynthesis, A Comprehensive Treatise. Cambridge: Cambridge University Press,

Stitt, M. 1991. Rising $\mathrm{CO}_{2}$ levels and their potential significance for carbon flow in photosynthetic cells. Plant Cell and Environment 14: 741-762.

Takeuchi, Y, Kubiske, ME, Isebrands, JG, Pregtizer, KS, Hendrey, G, Karnosky, DF. 2001. Photosynthesis, light and nitrogen relationships in a young deciduous forest canopy under open-air $\mathrm{CO}_{2}$ enrichment. Plant Cell and Environment 24: 1257-1268.

Tissue, DT, Thomas, RB, Strain, BR. 1993. Long-term effects of elevated $\mathrm{CO}_{2}$ and nutrients on photosynthesis and rubisco in loblolly pine seedlings. Plant Cell and Environment 16: 859865 .

Vitousek, PM, Howarth, RW. 1991. Nitrogen limitation on land and in the sea: How can it occur? Biogeochemistry 13: 87-115.

Winter, K, Virgo, A. 1998. Elevated $\mathrm{CO}_{2}$ enhances growth in the rain forest understory plant, Piper cordulatum, at extremely low light intensities. Flora 193: 841-853.

Wullschleger, SD. 1993. Biochemical limitations to carbon assimilation in $\mathrm{C}_{3}$ plants- a retrospective analysis of $\mathrm{A} / \mathrm{C}_{\mathrm{i}}$ curves from 109 species. Journal of Experimental Botany 44: 907-920. 
Table 3.1. Dark respiration $\left(R_{d}\right)$, apparent quantum efficiency $\left(Q_{e}, \mathrm{~mol} \mathrm{~mol}^{1}\right)$, light saturated maximum photosynthesis (? mol $\mathrm{CO}_{2} \mathrm{~m}^{-2} \mathrm{~s}^{-1}$ ), and the light compensation point (?, ? $\mathrm{mol} \mathrm{m}^{-2} \mathrm{~s}^{-1}$ ) of A. rubrum (ACRU), Carya glabra (CAGL), Cercis canadensis (CECA), and Liquidambar styraciflua (LIST) grown in ambient and elevated $\mathrm{CO}_{2}$. Measurements were made in June and September 2003 and each value is the mean of 4 to 6 individuals $( \pm 1 \mathrm{SE})$.

\begin{tabular}{lllllll}
\multicolumn{1}{c}{} & & & $R_{\mathrm{d}}$ & $Q_{\mathrm{e}}$ & $A_{\text {sat }}$ & $\mathrm{G}$ \\
\hline ACRU & June & Amb & $0.33(0.05)$ & $0.058(0.013)$ & $3.7(0.9)$ & $7.8(2.7)$ \\
& & Elv & $0.24(0.08)$ & $0.079(0.007)$ & $8.2(0.9)$ & $4.1(1.4)$ \\
& & & & & & \\
& Sept & Amb & $0.31(0.12)$ & $0.067(0.007)$ & $2.6(0.6)$ & $2.6(1.7)$ \\
& & Elv & $0.18(0.08)$ & $0.061(0.012)$ & $4.3(0.5)$ & $2.6(0.9)$ \\
CAGL & June & Amb & $0.31(0.05)$ & $0.065(0.015)$ & $5.3(0.5)$ & $5.8(1.3)$ \\
& & Elv & $0.20(0.05)$ & $0.070(0.021)$ & $6.2(0.3)$ & $4.0(2.2)$ \\
& & & & & & \\
& Sept & Amb & $0.30(0.06)$ & $0.060(0.008)$ & $3.5(0.4)$ & $5.7(1.6)$ \\
& & Elv & $0.16(0.03)$ & $0.062(0.008)$ & $4.3(0.4)$ & $1.9(1.1)$ \\
CECA & June & Amb & $0.30(0.05)$ & $0.049(0.011)$ & $4.2(0.3)$ & $7.3(1.5)$ \\
& & Elv & $0.42(0.05)$ & $0.079(0.017)$ & $7.0(0.6)$ & $6.5(1.5)$ \\
& & & & & & \\
& Sept & Amb & $0.40(0.08)$ & $0.079(0.005)$ & $4.3(0.3)$ & $5.1(1.0)$ \\
& & Elv & $0.19(0.11)$ & $0.103(0.017)$ & $5.5(0.2)$ & $1.6(1.2)$ \\
& & & & & & \\
LIST & June & Amb & $0.57(0.13)$ & $0.077(0.010)$ & $5.1(1.1)$ & $7.3(0.7)$ \\
& & Elv & $0.43(0.09)$ & $0.084(0.005)$ & $7.2(1.3)$ & $5.2(1.2)$ \\
& & & & & & \\
& Sept & Amb & $0.43(0.03)$ & $0.070(0.004)$ & $3.8(0.6)$ & $5.3(1.0)$ \\
& & Elv & $0.30(0.05)$ & $0.074(0.009)$ & $5.8(0.7)$ & $4.5(1.1)$
\end{tabular}


Table 3.2. Carboxylation efficiency $\left(\mathrm{Vc}_{\max }, ? \mathrm{~mol} \mathrm{CO} \mathrm{Cm}^{-2} \mathrm{~s}^{-1}\right.$ ), electron transport efficiency $\left(J_{\max }, ? \mathrm{~mol} \mathrm{CO} \mathrm{m}^{-2} \mathrm{~s}^{-1}\right.$ ), and the ratio of $\mathrm{Vc}_{\max } / J_{\max }$ of A. rubrum (ACRU), Carya glabra (CAGL), Cercis canadensis (CECA), and Liquidambar styraciflua (LIST) grown in ambient and elevated $\mathrm{CO}_{2}$. Measurements were made in June and September 2003 and each value is the mean of 4 to 6 individuals ( $\pm 1 \mathrm{SE})$. 
Table 3.3. Specific leaf area (SLA, $\mathrm{cm}^{2} \mathrm{~g}^{-1}$ ), foliar nitrogen concentration ([N $]_{\text {mass }}, \mathrm{mg} \mathrm{g}^{-1}$; $\left([\mathrm{N}]_{\text {area }}, \mathrm{g} \mathrm{m}^{-2}\right.$ ) total chlorophyll concentration $\left(\mathrm{Chl}_{\text {mass }}, \mathrm{mg} \mathrm{g}^{-1} ; \mathrm{Chl}_{\text {area }}, ? \mathrm{~g} \mathrm{~cm}^{-2}\right)$, chlorophyll a/b ratio $\left(\mathrm{Chl}_{a / b}\right)$ and dark-adapted chlorophyll fluorescence $\left(\mathrm{F}_{\mathrm{v}} / \mathrm{F}_{\mathrm{m}}\right.$, Rel.) of $A$. rubrum (ACRU), Carya glabra (CAGL), Cercis canadensis (CECA), and Liquidambar styraciflua (LIST) grown in ambient and elevated $\mathrm{CO}_{2}$. Measurements were made in June and September 2003 and each value is the mean of 4 to 6 individuals $( \pm 1 \mathrm{SE})$.

\begin{tabular}{|c|c|c|c|c|c|c|c|c|c|}
\hline & & & SLA & {$[\mathrm{N}]_{\text {mass }}$} & {$[\mathrm{N}]_{\text {area }}$} & $\mathrm{Chl}_{\text {mass }}$ & $\mathrm{Chl}_{\text {area }}$ & $\mathrm{Chl}_{a / b}$ & $\mathrm{~F}_{\mathrm{v}} / \mathrm{F}_{\mathrm{m}}$ \\
\hline \multirow[t]{4}{*}{$\overline{\mathrm{ACRU}}$} & June & $\mathrm{Amb}$ & $292.0(16.0)$ & $14.4(0.5)$ & $0.50(0.04)$ & $7.8(0.7)$ & $26.8(2.1)$ & $4.5(0.3)$ & $0.72(0.02)$ \\
\hline & & Elv & $283.1(13.3)$ & $14.5(0.8)$ & $0.52(0.03)$ & $7.7(1.2)$ & $27.1(3.6)$ & $3.5(0.4)$ & $0.76(0.01)$ \\
\hline & Sept & $\mathrm{Amb}$ & $286.1(21.8)$ & $13.1(0.5)$ & $0.46(0.04)$ & $9.1(2.4)$ & $32.2(3.9)$ & $2.5(0.2)$ & $0.73(0.01)$ \\
\hline & & Elv & $259.8(6.9)$ & $11.9(0.5)$ & $0.48(0.04)$ & $9.0(0.3)$ & 34.5 (1.7) & $2.5(0.2)$ & $0.71(0.02)$ \\
\hline \multirow[t]{4}{*}{ CAGL } & June & $\mathrm{Amb}$ & $282.1(17.4)$ & $16.5(0.7)$ & $0.59(0.02)$ & $5.9(0.6)$ & $22.5(2.9)$ & $4.1(0.6)$ & $0.75(0.02)$ \\
\hline & & Elv & $317.7(31.0)$ & $18.4(0.6)$ & $0.60(0.05)$ & $9.2(2.2)$ & $28.6(2.7)$ & $3.7(0.3)$ & $0.74(0.01)$ \\
\hline & Sept & $\mathrm{Amb}$ & $268.0(21.0)$ & $14.4(0.4)$ & $0.54(0.03)$ & $7.3(0.6)$ & $25.4(2.1)$ & $2.3(0.2)$ & $0.72(0.02)$ \\
\hline & & Elv & $242.0(20.2)$ & $14.2(0.6)$ & $0.57(0.07)$ & $5.7(1.1)$ & $23.0(3.3)$ & $3.0(0.6)$ & $0.74(0.02)$ \\
\hline \multirow[t]{4}{*}{ CECA } & June & $\mathrm{Amb}$ & $432.9(40.6)$ & $19.8(1.2)$ & $0.47(0.04)$ & $8.6(1.5)$ & $20.6(3.6)$ & $3.9(0.9)$ & $0.71(0.02)$ \\
\hline & & Elv & $501.7(35.3)$ & $23.6(1.0)$ & $0.49(0.06)$ & $11.4(1.7)$ & $22.8(3.3)$ & $2.7(0.2)$ & $0.77(0.01)$ \\
\hline & Sept & $\mathrm{Amb}$ & $377.5(32.5)$ & $16.6(0.5)$ & $0.45(0.03)$ & $10.4(2.1)$ & $27.3(2.2)$ & $2.4(0.2)$ & $0.71(0.02)$ \\
\hline & & Elv & $404.3(30.0)$ & $18.4(0.3)$ & $0.46(0.02)$ & $11.2(1.4)$ & $26.5(2.1)$ & $2.6(0.1)$ & $0.73(0.02)$ \\
\hline \multirow[t]{4}{*}{ LIST } & June & $\mathrm{Amb}$ & $368.6(32.9)$ & $15.6(0.7)$ & $0.44(0.04)$ & $6.7(0.5)$ & $18.8(1.9)$ & $4.8(1.4)$ & $0.75(0.03)$ \\
\hline & & Elv & $342.4(34.3)$ & $16.3(0.5)$ & $0.50(0.05)$ & $6.4(1.5)$ & $19.2(3.4)$ & $3.9(0.4)$ & $0.75(0.01)$ \\
\hline & Sept & $\mathrm{Amb}$ & $403.7(37.2)$ & $13.3(0.4)$ & $0.34(0.03)$ & $9.3(0.7)$ & $23.3(1.0)$ & $2.6(0.4)$ & $0.74(0.01)$ \\
\hline & & Elv & $405.4(12.8)$ & $13.2(0.3)$ & $0.39(0.02)$ & $9.6(0.5)$ & $29.4(1.7)$ & $2.9(0.3)$ & $0.76(0.02)$ \\
\hline
\end{tabular}


Figure 3.1. Photosynthetic-light response curves of four species of understory saplings growing under ambient $\left(\sim 380 \mu \mathrm{l} \Gamma^{-1} \mathrm{CO}_{2}\right.$; closed circles $)$ and elevated atmospheric $\mathrm{CO}_{2}\left(\sim 580\right.$ ? $1 \mathrm{I}^{1}$; open circles) in June of 2003 at the Duke Forest FACE experiment. Each point is a mean ( \pm 1 SE) of four to six measurements. 

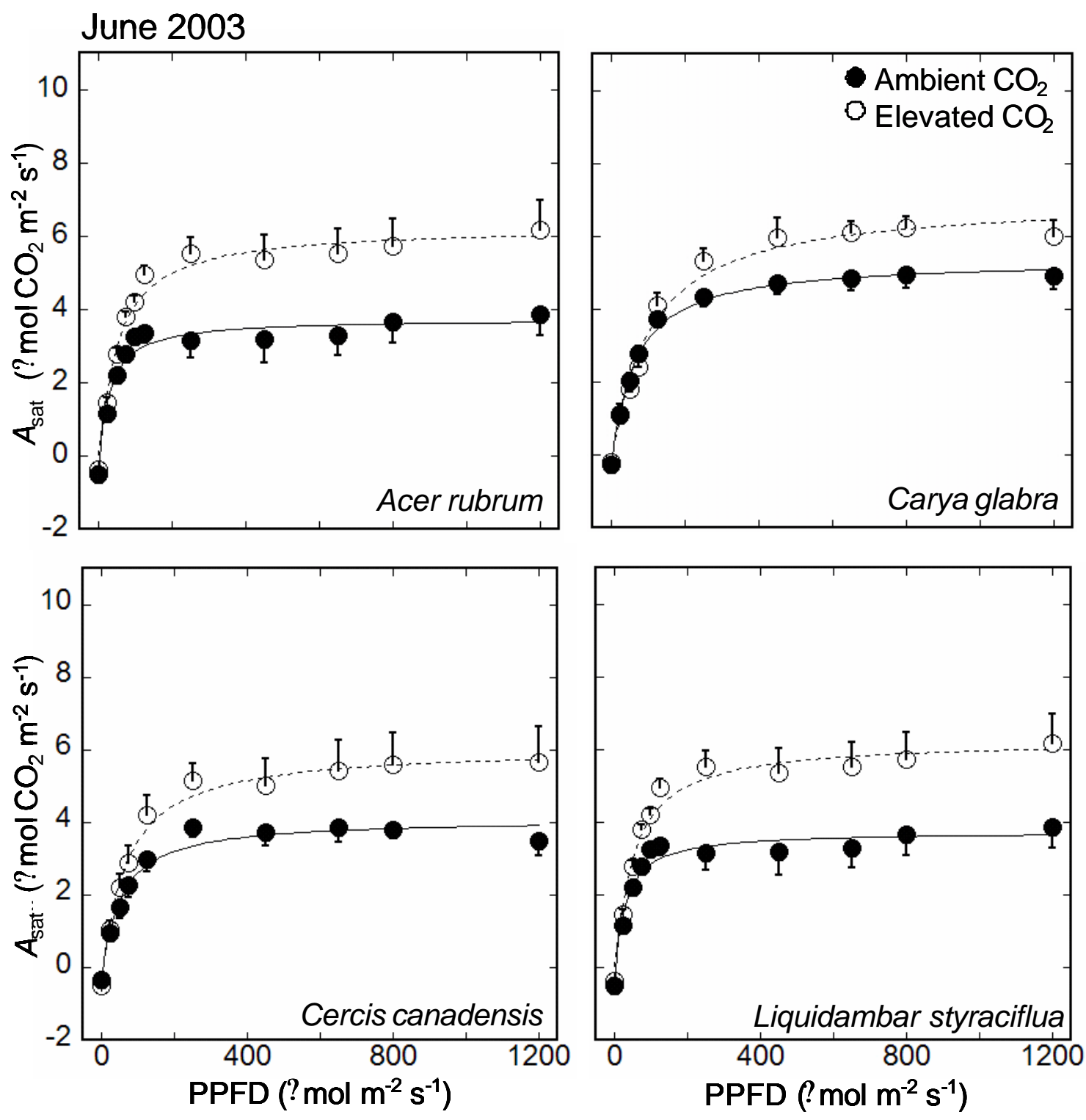
Figure 3.2. Photosynthetic-light response curves of four species of understory saplings growing under ambient $\left(\sim 380 \mu \mathrm{l} \Gamma^{-1} \mathrm{CO}_{2}\right.$; closed circles $)$ and elevated atmospheric $\mathrm{CO}_{2}\left(\sim 580\right.$ ? $1 \mathrm{I}^{1}$; open circles) in September of 2003 at the Duke Forest FACE experiment. Each point is a mean $( \pm 1$ $\mathrm{SE})$ of four to six measurements. 

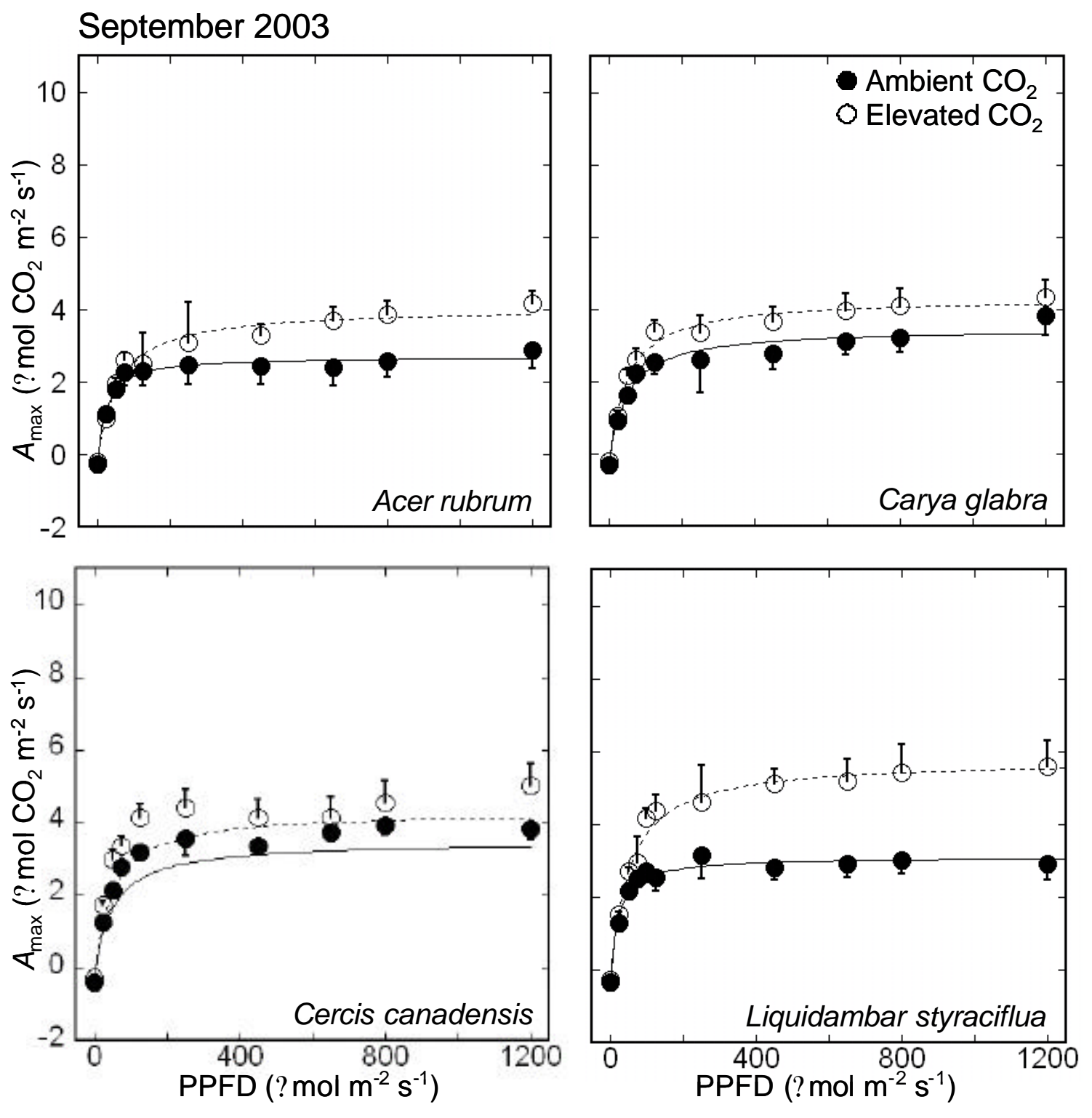
Figure 3.3. Chlorophyll fluorescence-PPFD relationships of four species of understory saplings growing under ambient $\left(\sim 380 \mu 1 \Gamma^{-1} \mathrm{CO}_{2} ;\right.$ closed circles) and elevated atmospheric $\mathrm{CO}_{2}(\sim 580$ ?1 $\mathrm{I}^{-1}$; open circles $)$ in June of 2003 at the Duke Forest FACE experiment. Each point is a mean $( \pm 1$ $\mathrm{SE}$ ) of four to six measurements. 

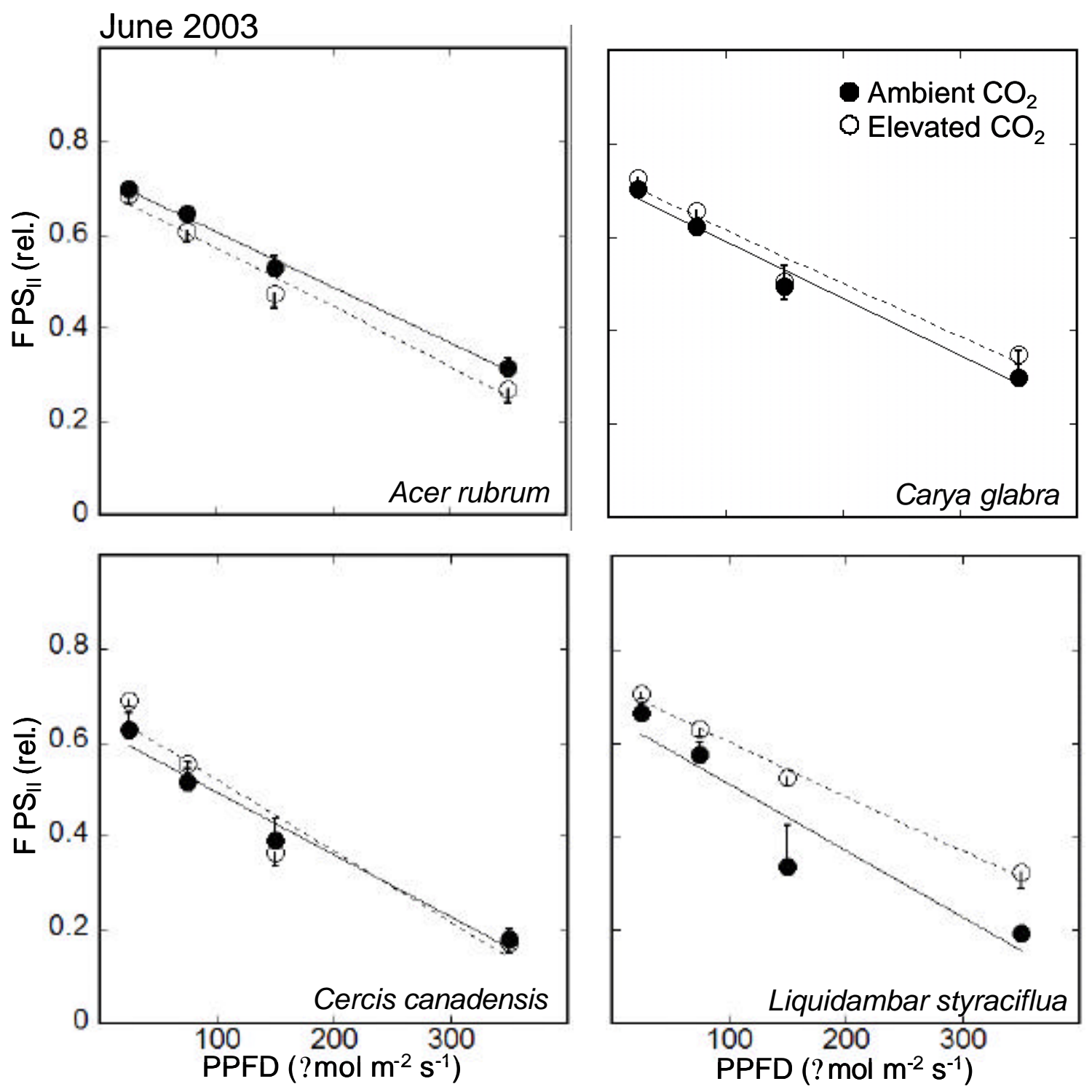
Figure 3.4. Chlorophyll fluorescence-PPFD relationships of four species of understory saplings growing under ambient $\left(\sim 380 \mu 1 \Gamma^{1} \mathrm{CO}_{2} ;\right.$ closed circles $)$ and elevated atmospheric $\mathrm{CO}_{2}(\sim 580 ? 1$ $\mathrm{1}^{-1}$; open circles) in September of 2003 at the Duke Forest FACE experiment. Each point is a mean $( \pm 1 \mathrm{SE})$ of four to six measurements. 

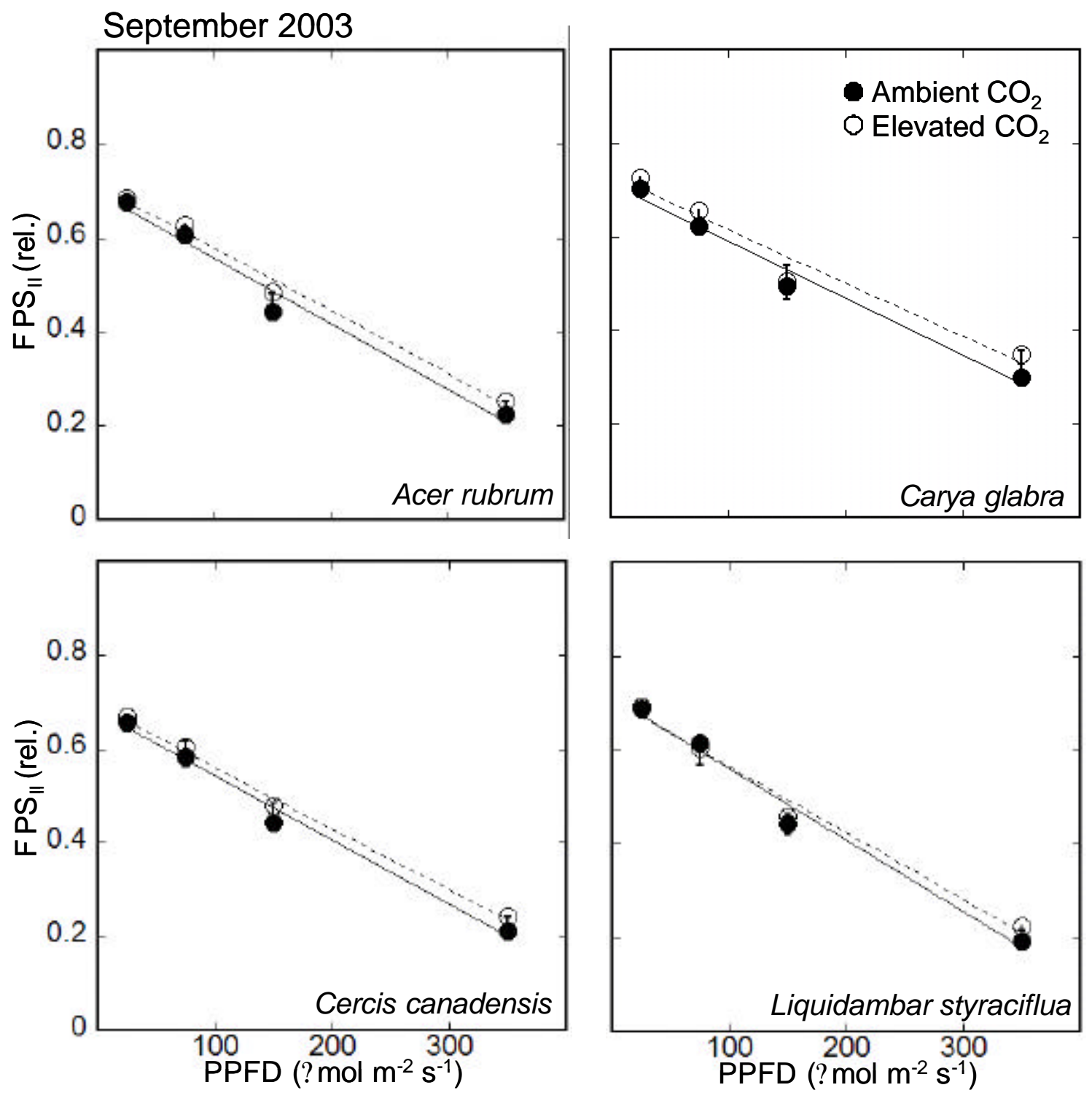
CHAPTER 4:

Growth response of Pinus taeda seedlings from four provenances to water availability and elevated carbon dioxide 


\begin{abstract}
The current study investigated the response of loblolly pine seedlings from four geographic regions to water availability and elevated atmospheric carbon dioxide. Loblolly pine seedlings originated from coastal North Carolina, the piedmont region of the southeastern United States, east Texas, and the Lost Pines region of Texas. Seedlings were grown in either ambient $(368 \pm 5 \mathrm{ppm})$ or elevated $(616 \pm 17 \mathrm{ppm}) \mathrm{CO}_{2}$ and three levels of water availability. The study was carried out in greenhouses over 16 weeks. Elevated $\mathrm{CO}_{2}$ stimulated the total biomass of loblolly pine seedlings. Water availability did not significantly affect seedling growth but did change the allocation of biomass. Seedlings grown under low water availability allocated more biomass to roots at the expense of stem tissue. Growth $\mathrm{CO}_{2}$ concentration and water availability did not affect the biomass production or allocation of seedlings interactively. Although seedling biomass was different between seed sources, biomass allocation was not. The effects of elevated $\mathrm{CO}_{2}$ and water availability on biomass accumulation and allocation were not dependent on seed source. Previous studies have exhibited a seed-source specific response of loblolly pine seedlings to water availability, however these studies were performed over a longer period of time. Further investigation of intra-specific responses of trees to environmental changes is necessary for future regional and global modeling projections of forest productivity.
\end{abstract}




\section{Introduction}

Water stress typically reduces the growth and photosynthesis of plants by decreasing leaf area production and the exchange of carbon dioxide between the leaf and the atmosphere (Kramer and Boyer 1995). Moderate water stress reduces net photosynthesis as a result of decreased stomatal conductance, thus decreasing the intercellular $\mathrm{CO}_{2}(\mathrm{Ci})$ concentration of the leaf. Under more severe water stress, plants can exhibit metabolic inhibition and changes in cellular activities associated with decreased water potential. Elevated atmospheric $\mathrm{CO}_{2}$ primarily stimulates leaf-level photosynthesis by competitively inhibiting the oxygenation of ribulose-1,5bisphosphate (RubP), thus reducing photorespiration and increasing the net efficiency of photosynthesis (Drake et al. 1997). Elevated $\mathrm{CO}_{2}$ also reduces stomatal conductance in many species, thus decreasing water loss and improving the water-use efficiency of elevated $\mathrm{CO}_{2}$ grown plants (Curtis and Wang 1998; Drake et al. 1997; Medlyn et al. 1999). Consequently, elevated atmospheric $\mathrm{CO}_{2}$ concentration may partially offset the negative effects of water stress by increasing the $\mathrm{CO}_{2}$ gradient that exists between the atmosphere and the intercellular spaces of the leaf and reducing water loss through the stomata (Groninger et al. 1996; Liang and Maruyama 1995; Samuelson and Seiler 1994; Tolley and Strain 1984; Tschaplinski et al. 1995). In a quantitative review of 123 observations, Poorter and Soba (2001) found that drought was the only stress condition where plants exhibited a higher response to elevated $\mathrm{CO}_{2}$ than under optimal conditions. For example, Tolley \& Strain (1984) and Tschaplinski et al. (1995) reported a greater relative stimulation of loblolly pine biomass by elevated $\mathrm{CO}_{2}$ under low water conditions than under optimal water conditions.

Several studies have examined the effects of elevated $\mathrm{CO}_{2}$ on different genotypes of the same species. Herbaceous species exhibit a wide range of intra-specific differences in their 
physiological responses to elevated $\mathrm{CO}_{2}$ (Curtis et al. 1994; Hunt et al. 1991; Steinger et al. 1997) but few studies have examined intra-specific variation in the responses of woody species to elevated $\mathrm{CO}_{2}$. Wang et al. (1994), using five genotypes of Populus tremuloides, reported a strong genotypic effect on photosynthetic responses to elevated $\mathrm{CO}_{2}$, but the interaction of genotype and $\mathrm{CO}_{2}$ treatment was not significant for biomass production.

The distribution of loblolly pine extends from eastern Maryland south to the northern portions of Florida and west to eastern Texas. Across this distribution, loblolly pine trees show geographic differentiation with respect to photosynthesis and biomass production (Boltz et al. 1986; Bongarten and Teskey 1987). In a study of loblolly pine seedlings from seven different seed sources, Bongarten and Teskey (1987) found strong seed source differences in the allocation of biomass such that loblolly pine seedlings originating from drier locations had higher root-shoot ratios than those originating from wetter locations. In another study determining the bio mass allocation of loblolly pine seedlings from four seed sources, Barnes (2002) reported differential allocation of biomass between seedlings from the different seed sources under drought conditions. Trees of coastal origin, an environment that receives abundant rainfall, consistently outgrow tress of northern origin in their juvenile and adult stages (Wakeley and Bercaw 1965; Wells and Wakeley 1966). Apparent differences between coastal and interior trees have been attributed to geographic differences in drought tolerance. These geographic differences in photosynthesis and biomass allocation of loblolly pine suggest that loblolly pine will show intra-specific variation in the response to elevated atmospheric $\mathrm{CO}_{2}$ with respect to water availability. Therefore, I hypothesized that the biomass and biomass allocation of loblolly pine seedlings from interior seed sources would respond more to elevated $\mathrm{CO}_{2}$ when grown in 
decreased water availability and seedlings from coastal seed sources would respond more to elevated $\mathrm{CO}_{2}$ at high levels of water availability.

\section{Materials and Methods}

Loblolly pine seeds from four distinct geographic regions across the natural distribution of loblolly pine were obtained from the Tree Improvement Program at North Carolina State University and the Forest Science Lab of the Texas Forest Service. The four geographic regions used in this study were coastal North Carolina, the piedmont region of the southeastern United States, east Texas, and the Lost Pines region of Texas. For a full description of the geographic differences in loblolly pine see Schmidtling (2001). After a 90 d period of cold stratification at $4^{\circ} \mathrm{C}$, seeds were planted in $10 \times 15 \mathrm{~cm}$ cylindrical pots in a mixture of coarse sand and natural soil (9:1 v/v). Natural soil was collected in a loblolly pine forest at the Duke University Forest (Durham, NC) to ensure inoculation of seedlings with mycorrhizal fungi. At harvest, mycorrhizal colonization was not quantified but was evident by the presence of abundant bifurcated root tips in the seedlings. Prior to germination, pots were assigned to one of two atmospheric $\mathrm{CO}_{2}$ concentrations (ambient, $\sim 370$ ppm or elevated, $\sim 600 \mathrm{ppm}$ ) and low, intermediate, or high water availability. The elevated treatment concentration of $600 \mathrm{ppm}$ was selected to approximate the projected atmospheric concentration near the mid-point of the current century (Schimel et al. 1996). Atmospheric carbon dioxide concentration was monitored and controlled by a commercially available $\mathrm{CO}_{2}$ monitoring system (CDMC-6, Green Air Products, Gresham Oregon, USA) with an attached solenoid valve that dispensed pure $\mathrm{CO}_{2}$ through polyethylene tubing $(6 \mathrm{~mm})$ with $1.5 \mathrm{~mm}$ holes placed every $1 \mathrm{~m}$ around the entire

perimeter of the greenhouse. To ensure adequate mixing of $\mathrm{CO}_{2}$, four multi-speed fans (20 inch diameter) were placed in the elevated $\mathrm{CO}_{2}$ greenhouse. Fans were also placed in the ambient 
$\mathrm{CO}_{2}$ greenhouse to mimic any micro-meteorological effects caused by the fans. Seedlings were randomly placed within each greenhouse and rotated within and between greenhouses to minimize the effect of position within a greenhouse and the effect of greenhouse on the seedlings during the study period. The average daytime atmospheric $\mathrm{CO}_{2}$ concentration in the ambient treatment was $368 \pm 5 \mathrm{ppm} \mathrm{CO}_{2}$ and in the elevated treatment the average concentration was $616 \pm 17 \mathrm{ppm} \mathrm{CO}_{2}$. The study was performed from late June through the end of October of 2003. The average daytime temperature through the study period was $26.7 \pm 0.2^{\circ} \mathrm{C}$ and the average nighttime temperature was $21.1 \pm 0.1^{\circ} \mathrm{C}$. A total of eight seedlings were present in each treatment combination of seed source, $\mathrm{CO}_{2}$ concentration, and water availability. After germination, seedlings in all treatment combinations were watered to saturation once a day with a nutrient solution containing $0.5 \mathrm{mM} \mathrm{N} ; 1 \mathrm{mM} \mathrm{P} ; 3$ mM K; $3 \mathrm{mM} \mathrm{Ca} ; 1.5 \mathrm{mM} \mathrm{Mg} ; 3 \mathrm{mM} \mathrm{S} ; 0.16 \mathrm{mM}$ Fe; $0.05 \mathrm{mM} \mathrm{B} ; 0.01 \mathrm{mM} \mathrm{Mn} ; 0.001 \mathrm{mM} \mathrm{Cu} ; 0.05$ ? M Mo; and 0.16 ? M Co for the first four weeks of the experiment. At week four, water treatments were started. Water availability treatments were maintained by watering high water level seedlings once each day to saturation, intermediate water level seedlings were watered once every three days, and low water seedlings were watered once each week. Watering regimes were maintained from week four of the experiment until termination of the experiment at week 16. At week 16, seedlings were harvested and divided into stems, needles, and roots. All plant parts were then dried to a constant mass at $65^{\circ} \mathrm{C}$ for 48 hours before being weighed for final biomass.

Data was analyzed for statistical significance using a three-way analysis of variance (ANOVA, $?=0.05)$ to test the main effects and interactions of $\mathrm{CO}_{2}$ concentration, water availability, and geographic seed source. Data were transformed as necessary to conform with the assumptions of ANOVA. 


\section{Results}

Elevated $\mathrm{CO}_{2}$ significantly stimulated $(\mathrm{F}=15.68, P=0.0001)$ the total biomass of loblolly pine seedlings $26 \%$, regardless of water availability and seed source (Figure 4.1 ). The total biomass did differ significantly $(\mathrm{F}=4.37, P=0.006)$ between seed sources. Seedlings originating from east Texas grew the most and seedlings from coastal North Carolina grew the least (Figure 4.1). There were no interactive effects of $\mathrm{CO}_{2}$, water availability, or seed source on the total biomass of seedlings. Elevated $\mathrm{CO}_{2}$ did not significantly affect biomass allocation to roots (F=0.33, $P=0.56)$, stems $(\mathrm{F}=1.44, P=0.23)$, or needles $(\mathrm{F}=0.96, P=0.33$; Table 4.1). However, the amount of biomass allocated to roots and stems was significantly altered by changes in water availability. Loblolly pine seedlings allocated $23 \%(\mathrm{~F}=10.95, P=0.0001)$ more biomass to stems when grown under high water availability. However under low water availability, loblolly pine seedlings allocated $12 \%\left((\mathrm{~F}=2.75, P=0.06)\right.$ more biomass to roots. Neither $\mathrm{CO}_{2}$ nor water availability altered the allocation of biomass to needles in the loblolly pine seedlings. There were also no significant interactions of water availability, $\mathrm{CO}_{2}$, or seed source on any of the biomass allocation parameters measured (Table 4.1)

\section{Discussion}

Generally elevated atmospheric $\mathrm{CO}_{2}$ stimulated the biomass of the loblolly pine seedlings. Although, seedling biomass increased with increasing $\mathrm{CO}_{2}$ concentration; bio mass allocation did not change with increasing $\mathrm{CO}_{2}$ concentration. However, decreased water availability did increase the root mass of the seedlings at the expense of stem mass. This is similar to the findings of Bongarten and Teskey (1987) where loblolly pine seedlings exhibited no significant differences in the amount of biomass allocated to leaves under optimal or drought stress conditions. Many studies have observed similar increases in loblolly pine seedling 
biomass with increasing $\mathrm{CO}_{2}$ (Groninger et al. 1996; Sionit et al. 1985; Tolley and Strain 1984; Tschaplinski et al. 1993). One previous study, Tschaplinski et al. (1993), also found that loblolly pine seedling biomass increased with elevated $\mathrm{CO}_{2}$ without altering the root to shoot ratio. In contrast to the current study, both Tolley and Strain (1984) and Groninger et al. (1996) found no evidence of $\mathrm{CO}_{2}$ or water stress-induced changes in biomass allocation in loblolly pine seedlings. Interestingly, the effect of elevated $\mathrm{CO}_{2}$ and water stress on the biomass of the seedling organs was not differential with respect to seed source. This follows the findings of Egli et al. (1998) where no provenance-specific responses were found in the above-ground growth and gas exchange of Fagus sylvatica and Picea abies. However, Houpis et al. (1999) found that the response of aboveground growth of Pinus ponderosa to elevated $\mathrm{CO}_{2}$ was provenance-specific in 8 of 15 seed sources examined.

Loblolly pine seedling biomass differed between seed sources but the allocation of biomass did not. This result is in contrast with that of Bongarten and Teskey (1987) who found differential biomass allocation in loblolly pine seedlings from different seed sources. The study also attributed the variation in allocation patterns to differences in growing season temperature and water availability in the source of origin of the seedlings. One difference between the current study and Bongarten and Teskey (1987) is the length of the experiment. The current study lasted only 16 weeks where the study of Bongarten and Teskey (1987) was carried out across a full year. As in the current study, Ledig (1983) found a lack of biomass allocation differences between seed sources of loblolly pine but this experiment was carried out over a relatively short period of time also. In the current study, the effect of elevated $\mathrm{CO}_{2}$ on seedling biomass was also not dependent on water availability, which contrasts the results of other studies (Groninger et al. 1996; Tolley and Strain 1984; Tschaplinski et al. 1993) where elevated $\mathrm{CO}_{2}$ 
increased biomass of tree seedlings more under high water availability than when the seedlings were grown under low water availability.

Although, the current study did not support the hypothesis that elevated $\mathrm{CO}_{2}$ will have geographic region-specific effects on the growth of loblolly pine, the topic deserves further investigation based on the more long-term work of Bongarten and Teskey (1987). The possibility of geographic specificity in the response of loblolly pine growth to changing environmental conditions, such as atmospheric $\mathrm{CO}_{2}$ and water availability, could have major impacts on the forestry industry by altering the intense management of the species that is already taking place. Long-term work investigating the geographic specific responses of loblolly pine and other tree species is needed to fully understand forest response in the future and to improve the accuracy of our regional and global modeling efforts. 


\section{References}

Allen, L.H., R.R. Valle, J.W. Mishoe and J.W. Jones 1994. Soybean leaf gas-exchange responses to carbon dioxide and water stress. Agronomy Journal. 86:625-636.

Barnes, A.D. 2002. Effects of phenology, water availability and seed source on loblolly pine biomass partitioning and transpiration. Tree Physiology. 22:733-740.

Boltz, B.A., B.C. Bongarten and R.O. Teskey 1986. Seasonal patterns of net photosynthesis of loblolly pine from diverse origins. Canadian Journal of Forest Research. 16:1063-1068.

Bongarten, B.C. and R.O. Teskey 1987. Dry weight partitioning and its relationship to productivity in loblolly pine seedlings from seven sources. Forest Science. 33:255-267.

Curtis, P. and X. Wang 1998. A meta-analysis of elevated $\mathrm{CO}_{2}$ effects on woody plant mass, form, and physiology. Oecologia. 113:299-313.

Curtis, P.S., A.A. Snow and A.S. Miller 1994. Genotype-specific effects of elevated $\mathrm{CO}_{2}$ on fecundity in wild radish (Raphanus raphanistrum). Oecologia. 97:100-105.

Drake, B., M. Gonzalez-Meler and S. Long 1997. More Efficent Plants: A consequence of ris ing atmospheric $\mathrm{CO}_{2}$ ? Annual Review of Plant Physiology and Plant Molecular Biology. 48:609-39.

Egli, P., S. Maurer, M.S. Gunthardt-Goerg and C. Korner 1998. Effects of elevated $\mathrm{CO}_{2}$ and soil quality on leaf gas exchange and above-ground growth in beech-spruce model ecosystems. New Phytologist. 140:185-196.

Groninger, J.W., J.R. Seiler, S.M. Zedaker and P.C. Berrang 1996. Effects of $\mathrm{CO}_{2}$ concentration and water availability on growth and gas exchange in greenhouse-grown miniature stands of loblolly pine and red maple. Functional Ecology. 10:708-716.

Houpis, J.L.J., P.D. Anderson, J.C. Pushnik and D.J. Anschel 1999. Among-provenance variability of gas exchange and growth in response to long-term elevated $\mathrm{CO}_{2}$ exposure. Water, Air, and Soil Pollution. 116:403-412.

Hunt, H., M. Trlica, E. Redente, J. Moore, J. Detling, T. Kittel, D. Walter, M. Fowler, D. Klein and E. Elliot 1991. Simulation model for the effects of climate change on temperate grassland ecosystems. Ecological Modelling. 53:205-246.

Kramer, P.J. and J.S. Boyer 1995. Water Relations of Plants and Soils. Academic Press, San Diego, CA USA. 495 p.

Ledig, F.T. 1983. The influence of genotype and environment on dry matter distribution in plants. In Plant research and agroforestry Ed. P.A. Huxley. International Council for Research in Agroforestry, Nairobi, Kenya. 
Liang, N. and K. Maruyama 1995. Interactive effects of $\mathrm{CO}_{2}$ enrichment and drought stress on gas exchange and water- use efficiency in Alnus firma. Environmental and Experimental Botany. 35:353-361.

Medlyn, B.E., F.W. Badeck, D.G.G. de Pury, C.V.M. Barton, M. Broadmeadow, R. Ceulemans, P. De Angelis, M. Forstreuter, M.E. Jach and S. Kellomaki 1999. Effects of elevated $\left[\mathrm{CO}_{2}\right]$ on photosynthesis in European forest species: a meta-analysis of model parameters. Plant Cell and Environment. 22:1475-1495.

Poorter, H. and M. Perez-Soba 2001. The growth response of plants to elevated $\mathrm{CO}_{2}$ under nonoptimal environmental conditions. Oecologia. 129:1-20.

Samuelson, L. and J. Seiler 1994. Red spruce seedling gas exchange in response to elevated $\mathrm{CO}_{2}$, water stress, and soil fertility treatments. Canadian Journal of Forest Research. 24:954959.

Schimel, D., D. Alves, I. Enting, M. Heimann, F. Joos, D. Raynaud and T. Wigley 1996. CO 2 and the carbon cycle. In Climate Change 1995: the science of climate change Eds. J.T. Houghton, L.G. Meira Filho, B.A. Callender, N. Harris, A. Kattenberg and K. Maskell. Cambridge University Press, New York, New York, USA, pp. 76-86.

Schmidtling, R.C. 2001. Southern Pine Seed Sources. US Forest Service, p. 35.

Sionit, N., B.R. Strain, H. Hellmers, G.H. Reichers and C.H. Jaeger 1985. Long-term atmospheric $\mathrm{CO}_{2}$ enrichment affects the growth and development of Liquidambar styraciflua and Pinus taeda seedlings. Canadian Journal of Forest Research. 15:468-471.

Steinger, T., C. Lavigne, A. Birrer, K. Groppe and B. Schmid 1997. Genetic variation in response to elevated $\mathrm{CO}_{2}$ in three grassland perennials - a field experiment with two competition regimes. Acta Oecologica. 18:263-268.

Tolley, L.C. and B.R. Strain 1984. Effects of carbon dioxide enrichment and water stress on growth of Liquidambar styraciflua and Pinus taeda seedlings. Canadian Journal of Botany. 62

Tschaplinski, T., D. Stewart and R. Norby 1995. Interactions between drought and elevated $\mathrm{CO}_{2}$ on osmotic adjustment and solute concentrations of tree seedlings. New Phytologist. 131:169-177.

Tschaplinski, T.J., R. Norby and S. Wullschleger 1993. Response of loblolly pine seedlings to elevated $\mathrm{CO}_{2}$ and fluctuating water supply. Tree Physiology. 13:283-296.

Wakeley, P.C. and T.E. Bercaw 1965. Loblolly pine provenance test at age 35. Journal of Forestry. 63:168-174. 
Wells, O.O. and P.C. Wakeley 1966. Geographic variation in survival, growth, and fusiform-rust infection of planted loblolly pine. Forest Science Monographs. 11:40. 
Figure 4.1. Total biomass of loblolly pine seedlings grown in ambient and elevated $\mathrm{CO}_{2}$ under three levels of water availability (low, intermediate, and high) originiating from a) the lost pines region, b) coastal North Carolina, c) the piedmont of the southeastern United States, and d) east Texas. Values are the means ? 1 SE. 

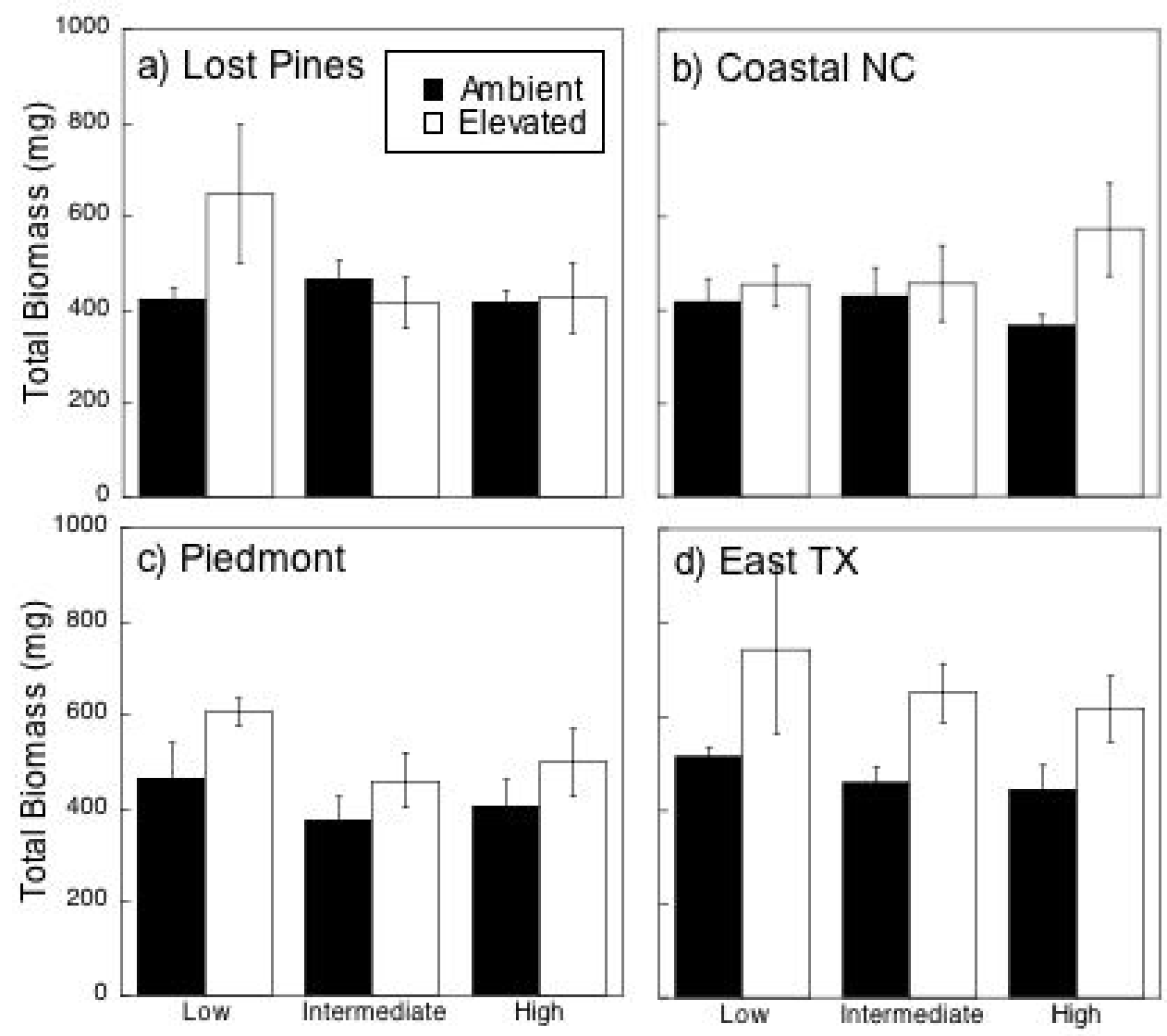
Table 4.1. Biomass allocation of loblolly pine seedlings from four distinct provenances grown under ambient and elevated $\mathrm{CO}_{2}$ and three levels of water availability (high, intermediate (Int), and low). Each value represent the mean of each group ? 1 SE.

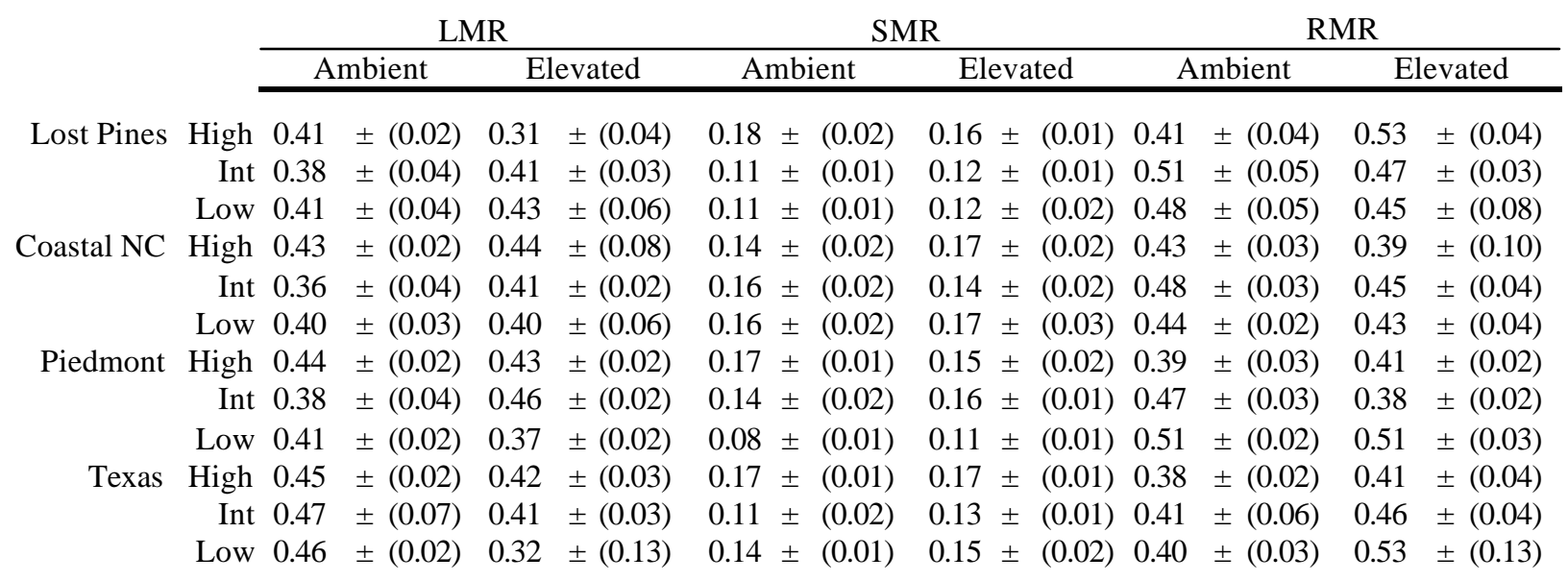




\section{CHAPTER 5:}

Net primary productivity of the first seven years of treatment at the Duke Forest FACE experiment estimated using PnET-II 


\begin{abstract}
The net primary productivity $(N P P)$ of forest ecosystems is expected to increase with increasing atmospheric $\mathrm{CO}_{2}$. However this increase in NPP may be modulated by changes in other climate variables, such as air temperature and precipitation that are also expected to change in the near future. In this study I modeled the NPP of the portions of the Duke Forest FACE experiment growing under ambient and elevated $\mathrm{CO}_{2}$. I also used three climate change scenarios to determine how the response of forest $N P P$ to elevated $\mathrm{CO}_{2}$ may change with future changes in precipitation and temperature. I then systematically decreased the foliar $\mathrm{N}$ concentration in both ambient and elevated $\mathrm{CO}_{2}$ to determine the foliar $\mathrm{N}$ concentration at which the stimulation of NPP by elevated $\mathrm{CO}_{2}$ would equal zero. I parameterized PnET-II, a monthly time step lumpedparameter forest productivity model with site specific and generalized physiological and physical variables. Model output is compared to measured estimates of NPP at the Duke Forest FACE experiment. I found good agreement between measured $N P P$ and model estimated NPP in both ambient and elevated $\mathrm{CO}_{2}$. Climate change scenarios showed an additive stimulation of $N P P$ by increased temperature and increased precipitation, but did not alter the stimulation of $N P P$ by elevated $\mathrm{CO}_{2}$. I also found that the foliar $\mathrm{N}$ concentration where elevated $\mathrm{CO}_{2}$ no longer increases forest NPP may be an unrealistic value in a field setting. This modeling effort suggests that other changes in physiological parameters other than the photosynthesis-foliar $\mathrm{N}$ relationship may be important in determining future forest productivity in changing climatic conditions.
\end{abstract}




\section{Introduction}

Forest ecosystems cover approximately $43 \%$ of the land area on Earth and account for nearly $70 \%$ of annual terrestrial net primary productivity (NPP) (Schlesinger 1997). NPP is the annual accumulation of plant biomass available to consumers and may represent an important sink for atmospheric carbon dioxide. Since the beginning of the industrial revolution, the

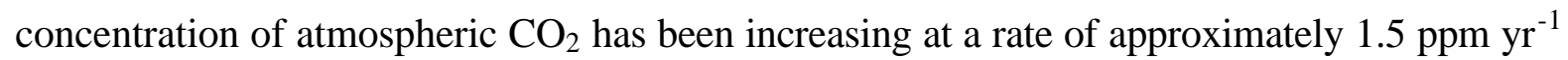
and coupled with this increase in atmospheric $\mathrm{CO}_{2}$ is an expected $3-7{ }^{\circ} \mathrm{C}$ increase in global mean temperature as well as changes in regional precipitation patterns (IPCC 2001). The Hadley 2 climate model, a general circulation model, has projected an increase in the average air temperature and a $0-10 \%$ increase in precipitation for North Carolina, USA, as the pre-industrial revolution atmospheric $\mathrm{CO}_{2}$ concentration (280 ppm) doubles (Kittel et al. 1997).

Increased atmospheric $\mathrm{CO}_{2}$ has been shown to stimulate the NPP of forest ecosystems (DeLucia et al. 1999), but this stimulation of NPP may be affected by other climatic variables (Hamilton et al. 2002). The Duke Forest Free- $\underline{A}$ ir $\underline{\mathrm{CO}_{2}} \underline{\text { Enrichment }}$ (FACE) experiment was developed to investigate the physiological and biogeochemical processes that regulate the response of an intact loblolly pine forest to elevated atmospheric $\mathrm{CO}_{2}$. A secondary objective of the Duke FACE experiment is to use this data to develop or parameterize models of carbon flux and storage that can be used to predict responses of forests to future changes in atmospheric $\mathrm{CO}_{2}$ (Hendrey et al. 1999). In the first two years (1997-1998) of the FACE study, NPP of the forest grown under elevated $\mathrm{CO}_{2}$ was stimulated by approximately 26\% (DeLucia et al. 1999). This $\mathrm{CO}_{2}$ induced stimulation of $N P P$ has continued throughout the experiment although inter-annual variation in the response of $N P P$ to $\mathrm{CO}_{2}$ enrichment has been observed (Dave Moore, unpublished data). The most recent analysis of tree growth at the Duke Forest FACE experiment 
suggests that this inter-annual variation in the response of $N P P$ to elevated $\mathrm{CO}_{2}$ is related to growing season temperature and annual precipitation, acting either independently or interactively (Dave Moore, unpublished data). Therefore, understanding the response of forest productivity to elevated $\mathrm{CO}_{2}$ under varying climatic conditions is necessary in order to predict the consequences of climate change on the loblolly pine forests of the southeastern United States.

In this study, I utilize a process-based forest productivity model, PnET-II, to estimate net primary productivity of the loblolly pine forest at the Duke FACE experiment grown under elevated $\mathrm{CO}_{2}$ for the first seven years of the experiment. I used three climate change scenarios that simulate climatic conditions that are expected to occur in the southeastern United States near the end of the $21^{\text {st }}$ century to examine the interactive effects of elevated $\mathrm{CO}_{2}$ with temperature or percipiataion on NPP. Because the response of forest growth to elevated $\mathrm{CO}_{2}$ is limited by nitrogen availability (Oren et al. 2001), I also determined the foliar nitrogen concentration at which elevated $\mathrm{CO}_{2}$ no longer increases forest $N P P$.

\section{Methods and Materials}

\section{Study Site}

The Duke Forest FACE experiment is located in a Pinus taeda plantation planted in 1983 after the re-generating forest was clear-cut in 1979. Since establishment, the plantation has not been managed to prevent the growth of other tree species. The forest is dominated by loblolly pine (Pinus taeda, 1733 stems ha $^{-1}$ ) along with a large number of sweetgum (Liquidambar

styraciflua, 620 stems ha $^{-1}$ ) and yellow poplar (Liriodendron tulipifera L., 68 stems ha-1) as well as other hardwood species present in the canopy and the understory. The forest is growing on a 
nutrient-poor, clay-rich loam soil that is typical of many upland areas in the southeastern United States.

The Duke Forest FACE experiment consists of six 30-m diameter FACE rings. Three of these rings serve as experimental control plots while the remaining three are replicate $\mathrm{CO}_{2}$ treatment plots. Each FACE ring consists of 32 pipes that extend from the forest floor through the canopy. Within each elevated $\mathrm{CO}_{2}$ treatment ring, these pipes deliver a controlled amount of $\mathrm{CO}_{2}$ with a target concentration of ambient $+200 ? 1 \mathrm{I}^{1} \mathrm{CO}_{2}$. The three remaining ambient control rings are equipped with blowers and receive the same volume of air as the elevated $\mathrm{CO}_{2}$ treatment rings to replicate any micrometeorological effects on the forest that occurs during the operation. Since the beginning of full operation of the Duke Forest FACE experiment in 1996 the forest has received $24 \mathrm{~h} \mathrm{~d}^{-1} \mathrm{CO}_{2}$ fumigation except on days when the air temperature was below $5{ }^{\circ} \mathrm{C}$ for more than one hour. Starting in the winter of 2003 , the forest was fumigated during daylight hours and when wind speeds are less than 15 m.p.h. For a complete description of the operating procedures of the Duke Forest FACE experiment see Hendrey et al. (1999).

\section{PnET-II Model}

The PnET-II model is a monthly time-step, lumped-parameter model that simulates the carbon and hydrologic cycles of forest ecosystems (Aber and Federer 1992). PnET-II was originally developed for use in northern forests but has been adapted for use in pine forests of the southeastern United States (McNulty et al. 1996). Data used to paramaterize the PnET-II model is derived either from literature values or measurements recorded at the site of interest. These parameters include characterizations of the vegetation, soil, and climate of the forest. The vegetation parameters thoroughly characterize the physiological and physical processes which 
control photosynthesis, light capture, and carbon allocation through the forest canopy. The single soil parameter characterizes the water holding capacity of the soil located at study site. Climate inputs include minimum and maximum temperature, photosynthetically active radiation (PAR) at the top of the canopy, and total precipitation. Climate data for the current study was collected at the Duke Forest FACE experiment and obtained from the lab of Dr. Ram Oren.

The physiological data used to parameterize PnET-II for the Duke Forest FACE experiment were mostly derived from data collected directly at the study site in the loblolly pine plantation growing under both ambient and elevated atmospheric $\mathrm{CO}_{2}$ (Table 5.1). The primary physiological parameter used in PnET-II, the photosynthesis-foliar N relationship, was obtained from data presented in Chapter 2 of this document. The standard error of this relationship was used to calculate a $95 \%$ confidence interval to provide an estimate of error for the modeled productivity values. Data for light interception and the respiration $\mathrm{Q}_{10}$ were obtained through personal communication with the lab of Dr. Evan DeLucia and other literature values derived at the Duke FACE experiment (Table 5.1). When data were not available from the study site, literature values were used, primarily from Sun et al. (2000) (Table 5.1).

\section{Climate \& Foliar N Change Senarios}

I developed a control climate scenario by averaging the minimum and maximum air temperature of each month of the year, as well as the annual precipitation recorded from 19972003 at the Duke Forest FACE experiment. The Hadley 2 global climate model was used to create 3 additional scenarios of climate change that may occur in North Carolina, USA near the end of the $21^{\text {st }}$ century. The first climate change scenario increased the mean minimum air temperature from $2.5-2.8^{\circ} \mathrm{C}$ and the mean maximum air temperature by $1.6-2.0^{\circ} \mathrm{C}$, depending 
on the month of the year, while not altering the annual precipitation. The second climate change scenario increased the monthly precipitation from $0-10 \%$ depending on season but did not change temperature. The final climate change scenario combined increased air temperatures with increased precipitation as stated above. To determine the foliar nitrogen concentration at which elevated $\mathrm{CO}_{2}$ no longer increased forest $N P P$, I systematically decreased the foliar $\mathrm{N}$ concentration and estimated the stimulation of $N P P$ by elevated $\mathrm{CO}_{2}$ until the stimulation equaled zero.

Statistics

Least squares linear regression models were applied to the relationships between the stimulation of modeled $N P P$ due to $\mathrm{CO}_{2}$ enrichment and mean growing season temperature and total annual precipitation. Relationships were considered significantly different than zero at a significance level of $?=0.05$.

\section{Results \& Discussion}

Modeled estimates of NPP for the Duke Forest FACE experiment indicate that NPP was stimulated by elevated $\mathrm{CO}_{2}$ in each year of treatment (Figure 5.1). Averaged across all years of the experiment, the stimulation of $N P P$ by elevated $\mathrm{CO}_{2}$ was $15 \%$. The largest stimulation was found in 1997, the first full year of treatment at the Duke FACE experiment, where elevated $\mathrm{CO}_{2}$ stimulated NPP by $21 \%$. The smallest stimulation of NPP was in the 2000 , where $\mathrm{CO}_{2}$ enrichment led to a $9 \%$ stimulation of $N P P$.

These modeled values of NPP show close agreement with allometric measurements of NPP at the Duke Forest FACE experiment during the second year of treatment (1988) (Hamilton et al. 2002) and fall into the range of NPP measurements of an 11 year old pine forest in NC,

USA (500-1235 $\mathrm{g} \mathrm{C} \mathrm{m}^{-2} \mathrm{yr}^{-1}$, Maier and Kress 2000). For the second year of treatment, Hamilton 
et al. (2002) reported that the $N P P$ of the ambient $\mathrm{CO}_{2}$-grown portion of the forest was $705 \mathrm{~g} \mathrm{C}$ $\mathrm{m}^{-2} \mathrm{yr}^{-1}$ and $897 \mathrm{~g} \mathrm{C} \mathrm{m}^{-2} \mathrm{yr}^{-1}$ in the elevated $\mathrm{CO}_{2}$ plots. Modeled estimates of NPP for the same year of the study were $759 \pm 113 \mathrm{~g} \mathrm{C} \mathrm{m}^{-2} \mathrm{yr}^{-1}$ under ambient $\mathrm{CO}_{2}$ and $907 \pm 181 \mathrm{~g} \mathrm{C} \mathrm{m}^{-2} \mathrm{yr}^{-1}$ in the elevated $\mathrm{CO}_{2}$-grown portion of the forest (Figure 5.1).

Current unpublished analyses of productivity at the Duke Forest FACE experiment show that the amount of stimulation of tree growth by elevated $\mathrm{CO}_{2}$ is correlated to growing season temperature (D. Moore, unpublished data). Modeled results of $N P P$ by elevated $\mathrm{CO}_{2}$ were not related to growing season temperature (Figure 5.2). This difference was unexpected because of the strong negative effect that temperature has on photosynthesis and strong positive effect temperature has on the stimulation of photosynthesis by elevated $\mathrm{CO}_{2}$ (Myers and Thomas 1999). Modeled results of $N P P$ by elevated $\mathrm{CO}_{2}$ was also not found to be related to annual precipitation (Figure 5.3). This result is consistent with the most current growth data analysis where a relationship was not found between precipitation and the $\mathrm{CO}_{2}$ stimulation of growth (D. Moore, unpublished data). It should be noted that the modeled results are for the seven years of the Duke FACE experiment and a relationship between the degree of stimulation of NPP by elevated $\mathrm{CO}_{2}$ and growing season temperature may be observed as the experiment progresses.

Modeled NPP was stimulated under each of the climate change scenarios of the Hadley 2 model (Figure 5.3). Growth in elevated $\mathrm{CO}_{2}$ stimulated the modeled NPP of the forest approximately $17 \%$ regardless of changes in climate. However, the modeled estimates of NPP in the temperature change scenario and the precipitation scenario resulted in much higher estimates of $N P P$ in both ambient and elevated $\mathrm{CO}_{2}$ grown portions of the forest. This response of $N P P$ to climate change was further increased when both precipitation and temperature were changed simultaneously. This simultaneous change in temperature and precipitation resulted in a 57\% 
increase of $N P P$ across all $\mathrm{CO}_{2}$ treatments (Figure 5.3). This additive effect of precipitation and temperature on $N P P$ in the current study is substantially larger than an increase in modeled $N P P$ of a loblolly pine forest growing in eastern NC performed by Sun et al. (2000), where a $25 \%$ increase in modeled forest $N P P$ was observed under similar climate change scenarios. One explanation for this observation may be that the increased temperature moved the average daytime temperature nearer the optimal range for photosynthesis, thus increasing the average daily net photosynthesis. However, this phenomenon may not be realized in an actual field-grown loblolly pine forest because of the ability of loblolly pine to alter the optimal operating temperature of photosynthesis (Strain et al. 1976). Also, a longer growing season may explain this large difference because the PnET-II model utilizes growing degree days to initiate and terminate tree growth and warmer winter days with more available water from increased precipitation may lead to an extension of the growing season. The foliar $\mathrm{N}$ concentration at which the stimulation of $N P P$ is no longer increased by $\mathrm{CO}_{2}$ enrichment was found at a critical level of $0.7 \%$ foliar $\mathrm{N}$. This value of foliar $\mathrm{N}$ concentration may be unrealistic in a field setting. Allen (1987) determined that at $1.1 \%$ foliar $\mathrm{N}$, the productivity of loblolly pine forests is critically limited by $\mathrm{N}$ availability. Therefore, the stimulation of $\mathrm{NPP}$ by elevated $\mathrm{CO}_{2}$ may never diminish to zero.

In conclusion, the PnET-II model was able to provide a good estimate of NPP of the loblolly pine forest growing under both ambient and elevated $\mathrm{CO}_{2}$ at the Duke Forest FACE experiment. However estimates of forest $N P P$ under future climatic conditions may be unrealistic because of physiological adjustments not accounted for in the PnET-II model. Future efforts to model forest productivity with the PnET-II model should follow an increased understanding of the physiological mechanisms that control the response of trees to elevated $\mathrm{CO}_{2}$ 
and the interaction of elevated $\mathrm{CO}_{2}$ and other abiotic factors such as water availability, temperature, and light availability on the growth and productivity of forest ecosystems. 


\section{References}

Aber, J., P. Reich and M. Goulden 1996. Extrapolating leaf $\mathrm{CO}_{2}$ exchange to the canopy: a generalized model of forest photosynthesis compared with measurements by eddy correlation. Oecologia. 106:257-265.

Aber, J.D. and A. Federer 1992. A generalized, lumped-parameter model of photosynthesis, evapotranspiration and net primary production in temperate and boreal forest ecosystems. Oecologia. 92:463-474.

Allen, H.L. 1987. Forest fertilizers. Journal of Forestry. 85:37-46.

Bazzaz, F.A. 1990. The response of natural ecosystems to the rising global $\mathrm{CO}_{2}$ levels. Annual Review of Ecology and Systematics. 21:167-196.

Blinn, C.R. and E.R. Buckner 1989. Normal foliar nutrient levels in North American forest trees: A summary. University of Minnesota, Minnesota Agricultural Experiment Station, St. Paul, MN.

Bowes, G. 1993. Facing the inevitable: plants and increasing atmospheric $\mathrm{CO}_{2}$. Annu. Rev. Plant Physiol. Plant Mol. Biol.:309-332.

Curtis, P., C. Vogel, X. Wang, K. Pregitzer, D. Zak, J. Lussenhop, M. Kubiske and J. Teeri 2000. Gas exchange, Leaf nitrogen, and growth efficiency of populus tremuloides in a $\mathrm{CO}_{2}$ enriched atmosphere. Ecological Applications. 10:3-17.

Curtis, P. and X. Wang 1998. A meta-analysis of elevated $\mathrm{CO}_{2}$ effects on woody plant mass, form, and physiology. Oecologia. 113:299-313.

Curtis, P.S., C.S. Vogel, K.S. Pregitzer, D.R. Zak and J.A. Teeri 1995. Interacting effects of soil fertility and atmospheric $\mathrm{CO}_{2}$ on leaf area growth and carbon gain physiology in Populus X euramericana (Dode) Guinier. New phytologist. 129:253-263.

DeLucia, E.H., J.G. Hamilton, S.L. Naidu, R.B. Thomas, J.A. Andrews, A. Finzi, M. Lavine, R. Matamala, J.E. Mohan, G.R. Hendrey and W.H. Schlesinger 1999. Net Primary Production of a Forest Ecosystem with Experimental $\mathrm{CO}_{2}$ Enrichment. Science. 284:177179.

DeLucia, E.H. and R.B. Thomas 2000. Photosynthetic responses to $\mathrm{CO}_{2}$ enrichment of four hardwood species in a forest understory. Oecologia. 122:11-19.

Denslow, J.S., J.C. Schultz, P.M. Vitousek and B.R. Strain 1990. Growth responses of tropical shrubs to treefall gap environments. Ecology. 71:165-179. 
Drake, B., M. Gonzalez-Meler and S. Long 1997. More Efficent Plants: A consequence of rising atmospheric $\mathrm{CO}_{2}$ ? Annual Review of Plant Physiology and Plant Molecular Biology. 48:609-39.

El Kohen, A. and M. Mousseau 1994. Interactive effects of elevated $\mathrm{CO}_{2}$ and mineral nutrition on growth and $\mathrm{CO}_{2}$ exchange of sweet chestnut seedlings (Castanea sativa). Tree Physiology. 14:679-690.

Evans, J. 1989. Photosynthesis and Nitrogen relationships in leaves of C3 plants. Oecologia. 78:9-19.

Evans, J. and J. Seemann 1989. The Allocation of protein in the photosynthetic apparatus; costs, consequences, and control. Photosynthesis:183-205.

Farquahar, G.D., S. von Caemmerer and J.A. Berry 1980. A biochemical model of photosynthetic $\mathrm{CO}_{2}$ fixation in $\mathrm{C}_{3}$ species. Planta. 149:178-190.

Farquhar, G.D. and T.D. Sharkey 1982. Stomatal conductance and photosynthesis. Annual Review of Plant Physiology. 33:317-345.

Field, C. and H.A. Mooney 1986. The photosynthesis-nitrogen relationship in wild plants. In On the Economy of Plant Form and Function Ed. T.J. Givnish. Cambridge University Press, Cambridge, UK, pp. 25-55.

Finzi, A.C., E.H. DeLucia, J.G. Hamilton, D.D. Richter and W.H. Schlesinger 2002. The nitrogen budget of a pine forest under free air $\mathrm{CO}_{2}$ enrichment. Oecologia. 132:567-578.

Gunderson, C. and S. Wullschleger 1994. Photosynthic Acclimation in trees to rising atmospheric $\mathrm{CO}_{2}$ : a broader perspective. Photosynthesis Research. 39:369-388.

Gunderson, C.A., J.D. Sholtis, S.D. Wullschleger, D.T. Tissue, P.J. Hanson and R.J. Norby 2002. Environmental and stomatal control of photosynthetic enhancement in the canopy of a sweetgum (Liquidambar styraciflua L.) plantation during 3 years of $\mathrm{CO}_{2}$ enrichment. Plant Cell and Environment. 25:379-393.

Hamilton, J., E.H. DeLucia, K. George, S.L. Naidu, A. Finzi and W.H. Schlesinger 2002. Forest carbon balance under elevated $\mathrm{CO}_{2}$. Oecologia. 131:250-260.

Harley, P.C., R.B. Thomas, J.F. Reynolds and B.R. Strain 1992. Modeling photosynthesis of cotton grown in elevated $\mathrm{CO}_{2}$. Plant, Cell and Environment:271-282.

Hattenschwiler, S. 2001. Tree seedling growth in natural deep shade: Functional traits related to interspecific variation in response to elevated $\mathrm{CO}_{2}$. Oecologia. 129:31-42. 
Hendrey, G.R., D.S. Ellsworth, K.F. Lewin and J. Nagy 1999. A free-air enrichment system for exposing tall forest vegetation to elevated atmospheric $\mathrm{CO}_{2}$. Global Change Biology. 5:293-309.

Herrick, J. and R. Thomas 2001. No photosynthic down-regulation in sweet gum trees (Liquidambar styraciflua L.) after 3 yrs. of $\mathrm{CO}_{2}$ enrichment at the Duke forest face experiment. Plant Cell and Environment. 24:53-64.

Herrick, J.D. and R.B. Thomas 1999. Effects of $\mathrm{CO}_{2}$ enrichment on the photosynthetic light response of sun and shade leaves of canopy sweetgum trees (Liquidambar styraciflua) in a forest ecosystem. Tree Physiology. 19:779-786.

Ingestad, T. and V. Stoy 1982. Mineral nutrition of wheat (Triticum aestivum cultivar Prins), rye (Secale cereale), barley (Hordeum vulgare cultivar Ingrid) and oat (Avena sativa cultivar Sol II) seedlings in nutrient solutions. Swedish Journal of Agricultural Research. 12:185192.

IPCC 2001. IPCC Third Assessment Report-Climate Change 2001: The Scientific Basis Eds. J.T. Houghton, Y. Ding, D.J. Griggs, M. Noguer, P.J. van der Linden, X. Dai, K. Maskell and C.A. Johnson. Cambridge University Press, Cambridge, UK.

Kittel, T.G.F., J.A. Royle, C. Daly, N.A. Rosenbloom, W.P. Gibson, H.H. Fisher, D.S. Schimel, L.M. Berliner and V. Participants 1997. A gridded historical (1895-1993) bioclimate dataset for the conterminous United States. In Proceedings of the 10th Conference on Applied Climatology. American Meteorological Society, Reno, NV USA.

Kobe, R.K., S.W. Pacala, J.A. Silander and C.D. Canham 1995. Juvenile tree survivorship as a component of shade tolerance. Ecological Applications. 5

Kubiske, M., D. Zak, K. Pregitzer and Y. Takeuchi 2002. Photosynthesis acclimation of overstory Populus tremuloides and understory Acer saccharum to elevated atmospheric $\mathrm{CO}_{2}$ concentration: interactions with shade and soil nitrogen. Tree Physiology. 22:321329.

Long, S.P. and B.G. Drake 1991. Effect of long-term elevation of $\mathrm{CO}_{2}$ concentration in the field on the quantum yield of photosynthesis of the $\mathrm{C}_{3}$ sedge, Scirpus olneyi. Plant Physiology. 96:221-226.

McNulty, S.G., J.M. Vose and W.T. Swank 1996. Potential climate change effects on loblolly pine forest productivity and drainage across the southern United Sates. Ambio. 25:449453.

Medlyn, B.E., F.W. Badeck, D.G.G. de Pury, C.V.M. Barton, M. Broadmeadow, R. Ceulemans, P. De Angelis, M. Forstreuter, M.E. Jach and S. Kellomaki 1999. Effects of elevated $\left[\mathrm{CO}_{2}\right]$ on photosynthesis in European forest species: a meta-analysis of model parameters. Plant Cell and Environment. 22:1475-1495. 
Myers, D.A., R.B. Thomas and E.H. DeLucia 1999. Photosynthetic capacity of loblolly pine (Pinus taeda L.) trees during the first year of carbon dioxide enrichment in a forest ecosystem. Plant Cell and Environment. 22:473-481.

Naumburg, E. and D.S. Ellsworth 2000. Photosynthetic sunfleck utilization potential of understory saplings growing under elevated CO2 in FACE. Oecologia. 122:163-174.

Norby, R.J., S.D. Wullschleger, C.A. Gunderson, D.W. Johnson and R. Ceulemans 1999. Tree responses to rising $\mathrm{CO} 2$ in field experiments: implications for the future forest. Plant, Cell ,and Environment. 22:683-714.

Oren, R., D.S. Ellsworth, K.H. Johnsen, N. Phillips, B.E. Ewers, C. Maier, K.V.R. Schafer, H. McCarthy, G. Hendrey, S.G. McNulty and G.G. Katul 2001. Soil fertility limits carbon sequestration by forest ecosystems in a $\mathrm{CO}_{2}$-enriched atmosphere. Nature. 411:469-472.

Osborne, C., B. Drake, J. LaRoche and S. Long 1997. Does Long-term evelation of CO2 concetraction increase photosynthesis in forest floor vegetation. Plant Physiol. 114:337344.

Pacala, S.W., C.D. Canham, J.A. Silander and R.K. Kobe 1994. Sapling growth as a function of resources in a northern temperate forest. Canadian Journal of Forest Research. 24:21722183.

Pearcy, R.W. 1983. The light environment and growth of $\mathrm{C}_{3}$ and $\mathrm{C}_{4}$ tree species in the understorey of a Hawaiian forest. Oecologia. 58:19-25.

Peterson, A. and CMEAL participants 1999. Reconciling the apparent differences between massand area-based expressions of the photosynthesis-nitrogen relationships. Oecologia. 118:144-150.

Peterson, A., Y. Luo, C. Field and C. Participants 1999. The photosynthesis- leaf nitrogen relationships at ambient and elevated atmospheric carbon dioxide: a meta-analysis. Global Change Biology. 5:331-346.

Piatek, K. and H.L. Allen 2000. Site preparation effects on foliar N and P use, retranslocation, and transfer to litter in 15-year old Pinus taeda. Forest Ecology and Management. 129:143-152.

Poorter, H. and M. Perez-Soba 2001. The growth response of plants to elevated $\mathrm{CO}_{2}$ under nonoptimal environmental conditions. Oecologia. 129:1-20.

Porra, R.J., W.A. Thompson and P.E. Kriedemann 1989. Determination of accurate extinction coefficients and simultaneous equations for assaying chlorophylls a and b extracted with four different solvents:verification of the concentration of chlorophyll standards by atomic absorption spectroscopy. Biochimica et Biophysica Acta. 975:384-394. 
Prioul, J.L. and P. Chartier 1977. Partitioning of transfer and carboxylation components of intracellular resistance to photosynthetic $\mathrm{CO}_{2}$ fixation: A critical analysis of the methods used. Annals of Botany. 41:789-800.

Radoglou, K.M., P. Aphalo and P.G. Jarvis 1992. Response of photosynthesis, stomatal conductance and water use efficiency to elevated $\mathrm{CO}_{2}$ and nutrient supply in acclimated seedlings of Phaseolus vulgaris L. Annals of Botany. 70:257-264.

Reich, P.B., M.B. Walters and D.E. Ellsworth 1997. From tropics to tundra: global convergence in plant functioning. Proceedings of the National Academy of Sciences. 94:13730-13734.

Reynolds, J.F., P.R. Kemp, B. Acock, J. Chen and D.L. Moorehead 1996. Progress, limitations, and challenges in modeling the effects of elevated $\mathrm{CO}_{2}$ on plants and ecosystems. In Carbon Dioxide and Terrestrial Ecosystems Eds. G.W. Koch and H.A. Mooney. Academic Press, San Diego, USA, pp. 347-379.

Richter, D.D., D. Markewitz, P.R. Heine, V. Jin, J. Raikes, K. Tian and C.G. Wells 2000. Legacies of agriculture and forest regrowth in the nitrogen of old-field soils. Forest Ecology and Management. 138:233-248.

Rogers, A. and D.S. Ellsworth 2002. Photosynthetic acclimation of Pinus taeda (loblolly pine) to long-term growth in elevated $p \mathrm{CO}_{2}$ (FACE). Plant Cell and Environment. 25:851-858.

Sage, R.F. 1994. Acclimation of photosynthesis to increasing atmospheric $\mathrm{CO}_{2}$ : the gas exchange perspective. Photosynthesis Research. 39:741-762.

Schafer, K.V.R., R. Oren, C. Lai and G.G. Katul 2002. Hydrologic balance in an intact temperate forest ecosystem under ambient and elevated atmospheric $\mathrm{CO}_{2}$ concentration. Global Change Biology. 8

Schlesinger, W.H. 1997. Biogeochemistry: An analysis of global change. Academic Press, San Diego.

Schreiber, U., W. Bilger, H. Hormann and C. Neubauer 1998. Chlorophyll fluorescence as a diagnostic tool: basics and some aspects of practical relevance. In Photosynthesis, A Comprehensive Treatise Ed. A.S. Raghavendra. Cambridge University Press, Cambridge.

Sharkey, T.D. 1985. Photosynthesis in intact leaves of $\mathrm{C}_{3}$ plants: physics, physiology and rate limitations. Botany Review. 51

Stitt, M. 1991. Rising $\mathrm{CO}_{2}$ levels and their potential significance for carbon flow in photosynthetic cells. Plant Cell and Environment. 14:741-762.

Sun, G., D.M. Amatya, S.G. McNulty, R.W. Skaggs and J.H. Hughes 2000. Climate change impacts on the hydrology and productivity of a pine plantation. Journal of the American Water Resources Association. 36:367-374. 
Takeuchi, Y., M.E. Kubiske, J.G. Isebrands, K.S. Pregtizer, G. Hendrey and D.F. Karnosky 2001. Photosynthesis, light and nitrogen relationships in a young deciduous forest canopy under open-air $\mathrm{CO}_{2}$ enrichment. Plant Cell and Environment. 24:1257-1268.

Terashima, I. and J.R. Evans 1988. Effects of light and nitrogen nutrition on the organization of the photosynthetic apparatus in spinach. Plant and Cell Physiology. 29:143-155.

Tissue, D.T., R.B. Thomas and B.R. Strain 1993. Long-term effects of elevated $\mathrm{CO}_{2}$ and nutrients on photosynthesis and rubisco in loblolly pine seedlings. Plant Cell and Environment. 16:859-865.

Vitousek, P.M. and R.W. Howarth 1991. Nitrogen limitation on land and in the sea: How can it occur? Biogeochemistry. 13:87-115.

von Caemmerer, S. and G.D. Farquhar 1981. Some relationships between biochemistry of photosynthesis and gas exchange of leaves. Planta. 153:376-387.

Ward, J.K. and B.R. Strain 1999. Elevated CO2 studies: past, present and future. Tree Physiology. 19:211-220.

Winter, K. and A. Virgo 1998. Elevated $\mathrm{CO}_{2}$ enhances growth in the rain forest understory plant, Piper cordulatum, at extremely low light intensities. Flora. 193:841-853.

Wullschleger, S.D. 1993. Biochemical limitations to carbon assimilation in $\mathrm{C}_{3}$ plants- a retrospective analysis of $\mathrm{A} / \mathrm{C}_{\mathrm{i}}$ curves from 109 species. Journal of Experimental Botany. 44:907-920. 
Table 5.1. Duke Forest FACE experiment specific parameters that were changed from earlier modeling efforts of Aber and Federer (1992) and Sun et al. (2000) used to estimate net primary productivity of the portions of the forest growing under ambient and elevated $\mathrm{CO}_{2}$ using the PnET-II forest productivity model.

\begin{tabular}{lccc}
\multicolumn{1}{c}{ Paramater Definition } & $\begin{array}{c}\text { Ambient } \\
\mathbf{C O}_{2}\end{array}$ & $\begin{array}{c}\text { Elevated } \\
\mathbf{C O}_{2}\end{array}$ & Source \\
\hline Intercept of Amax-N Relationship & 5.80 & 8.84 & Chapter 2 \\
Slope of Amax-N Relationship $\left(\mathrm{mmol} \mathrm{CO}_{2} \mathrm{~m}^{-2} \mathrm{~s}^{-1}\right)$ & 32.38 & 52.68 & Chapter 2 \\
Optimum Temperature for Photosynthesis $\left({ }^{\circ} \mathrm{C}\right)$ & 24 & 24 & $\begin{array}{c}\text { Sun et al. 2002 } \\
\text { Hamilton et al. }\end{array}$ \\
$Q_{10}$ for Leaf Respiration & 2.1 & 2.7 & 2001 \\
Light Attenuation Constant & 0.5 & 0.5 & E.H. DeLucia \\
Foliar N Concentration $(\%)$ & 1.32 & 1.32 & Chapter 2 \\
Specific Leaf Weight $\left(\mathrm{g} \mathrm{m}^{-2}\right)$ & 100 & 100 & Chapter 2
\end{tabular}


Figure 5.1. Net primary productivity (NPP) of portions of the Duke Forest FACE experiment growing under ambient (closed circles, solid line) and elevated (open circles, dashed line) $\mathrm{CO}_{2}$ from 1997 to 2003 estimated using the PnET-II forest productivity model. Values represent model output \pm 1 S.E. determined by using the lower and upper standard errors of model parameters measured by the investigator. 


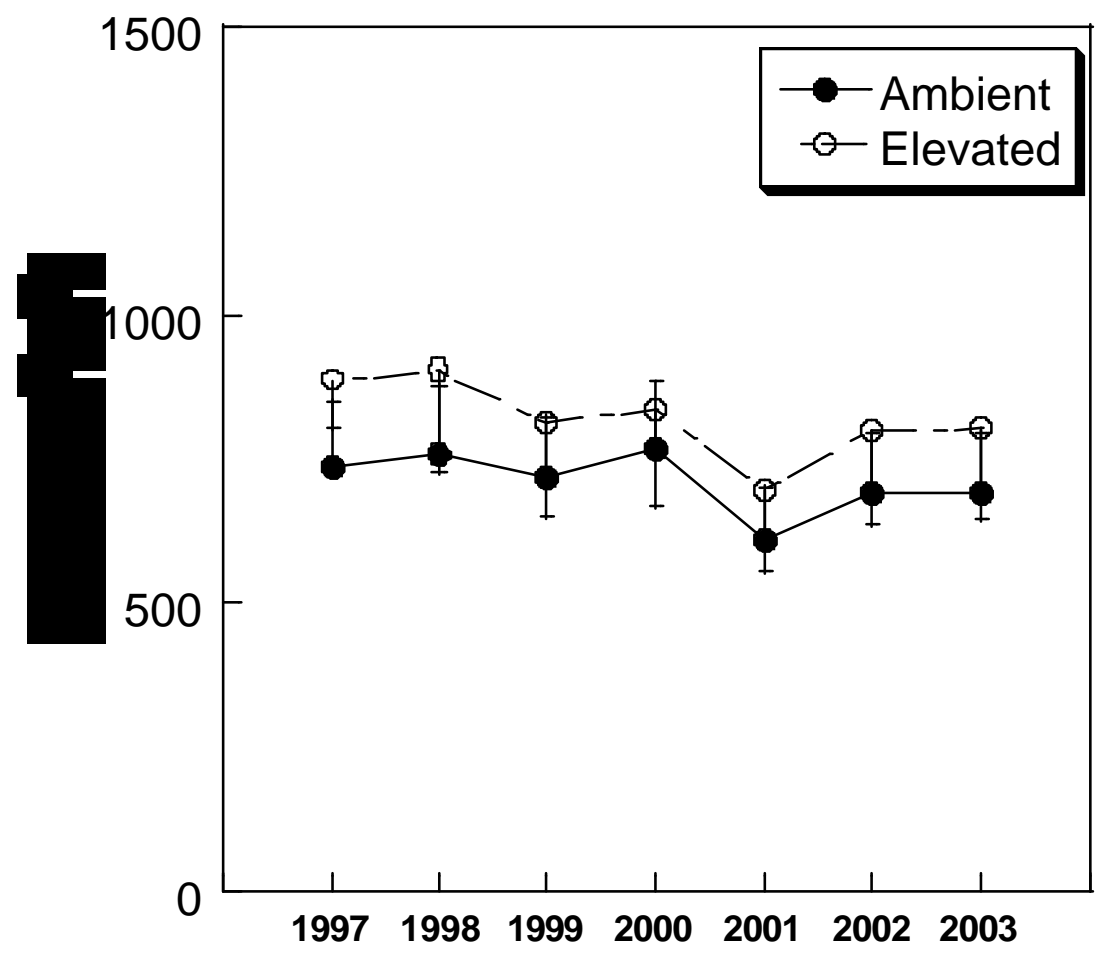


Figure 5.2. Relationship between the stimulation of NPP due to elevated $\mathrm{CO}_{2}$ versus mean growing season temperature. Regression equation: $\mathrm{y}=1.05+0.005 \mathrm{x}, R^{2}=0.18, P=0.1689$. 


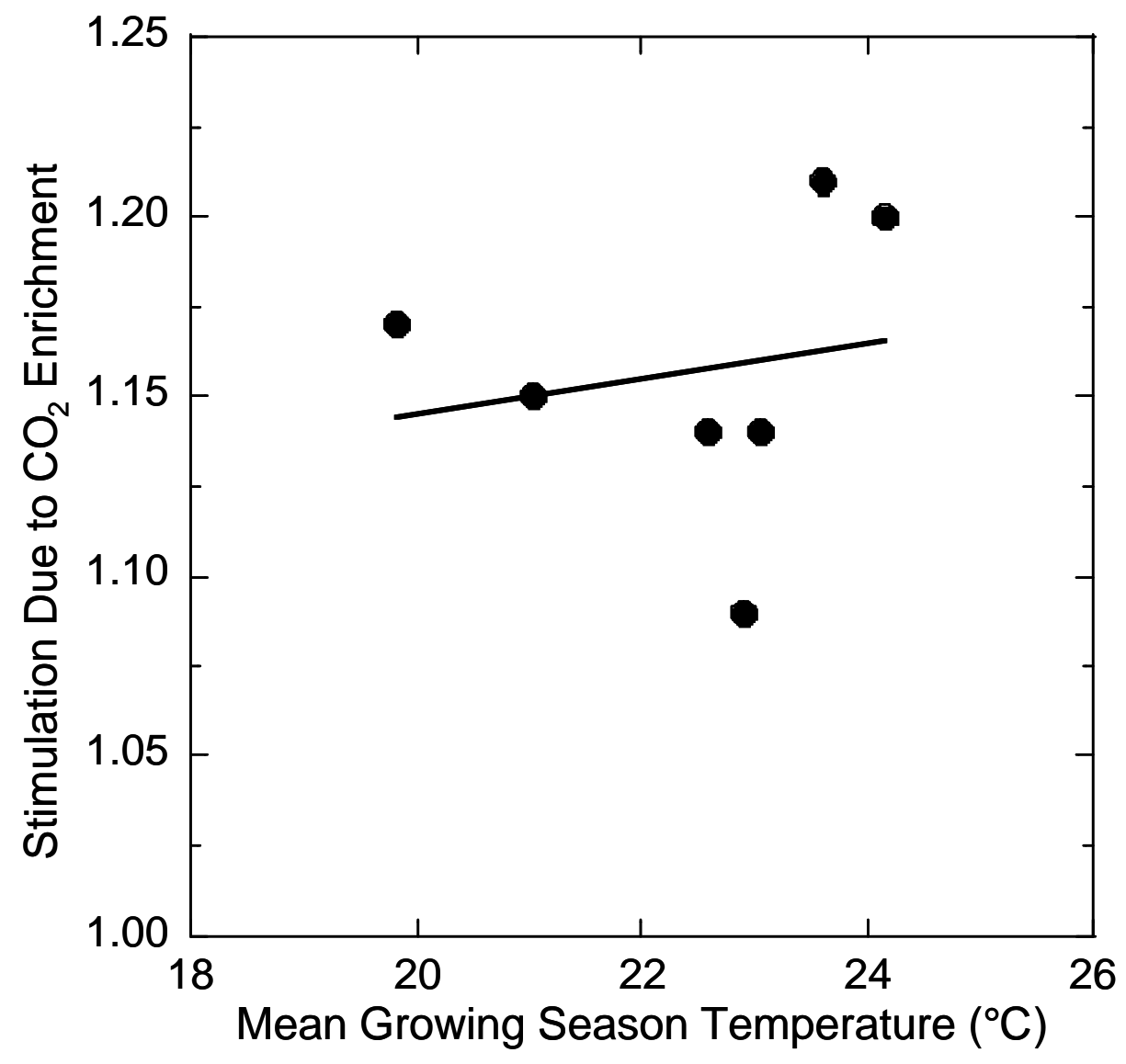


Figure 5.2. Relationship between the stimulation of NPP due to elevated $\mathrm{CO}_{2}$ versus annual precipitation. Regression equation: $\mathrm{y}=1.14+0.00016 \mathrm{x}, R^{2}=0.17, P=0.1459$. 


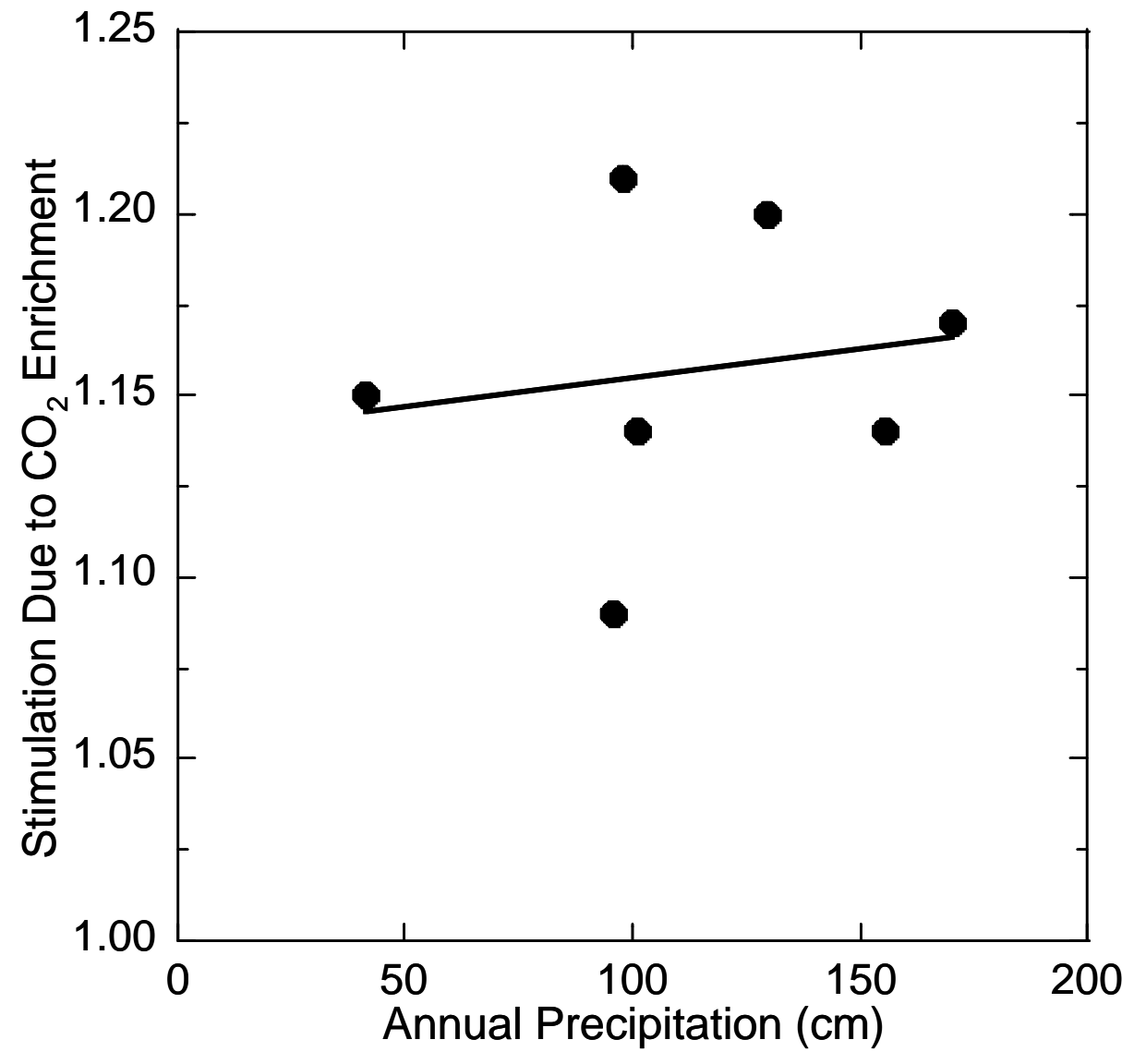


Figure 5.3. Modeled NPP of the Duke Forest FACE experiment grown under ambient (closed bars) and elevated (open bars) $\mathrm{CO}_{2}$ using a control climate scenario and three climate change scenarios, temperature only (Temp), precipitation only (Precip), and both temperature and precipitation (Both). 


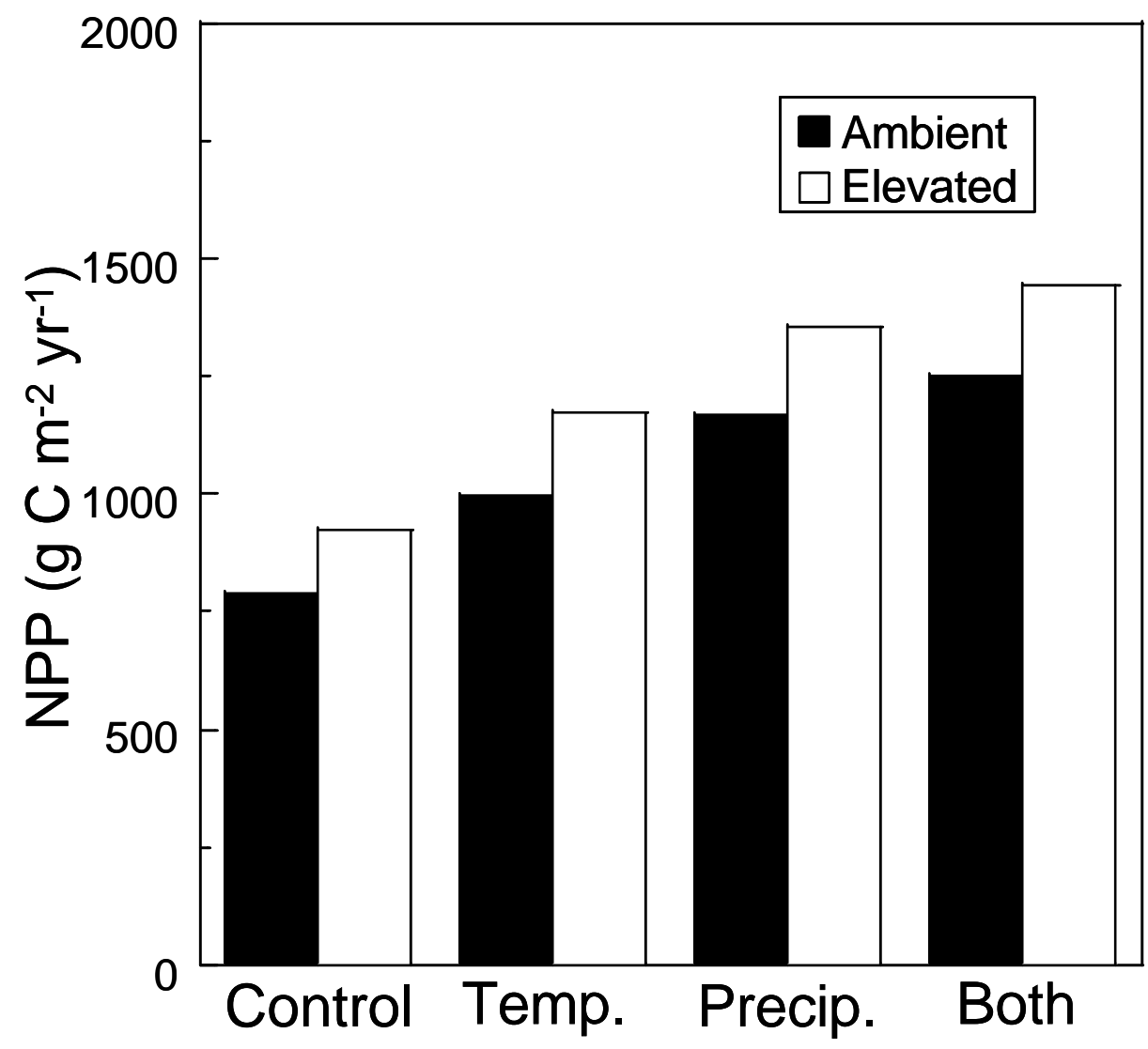


Figure 5.4. The stimulation of NPP by $\mathrm{CO}_{2}$ enrichment versus $\%$ foliar $\mathrm{N}$ concentration. The stimulation of NPP by $\mathrm{CO}_{2}$ enrichment reaches zero at $0.70 \%$ foliar $\mathrm{N}$ concentraton. 


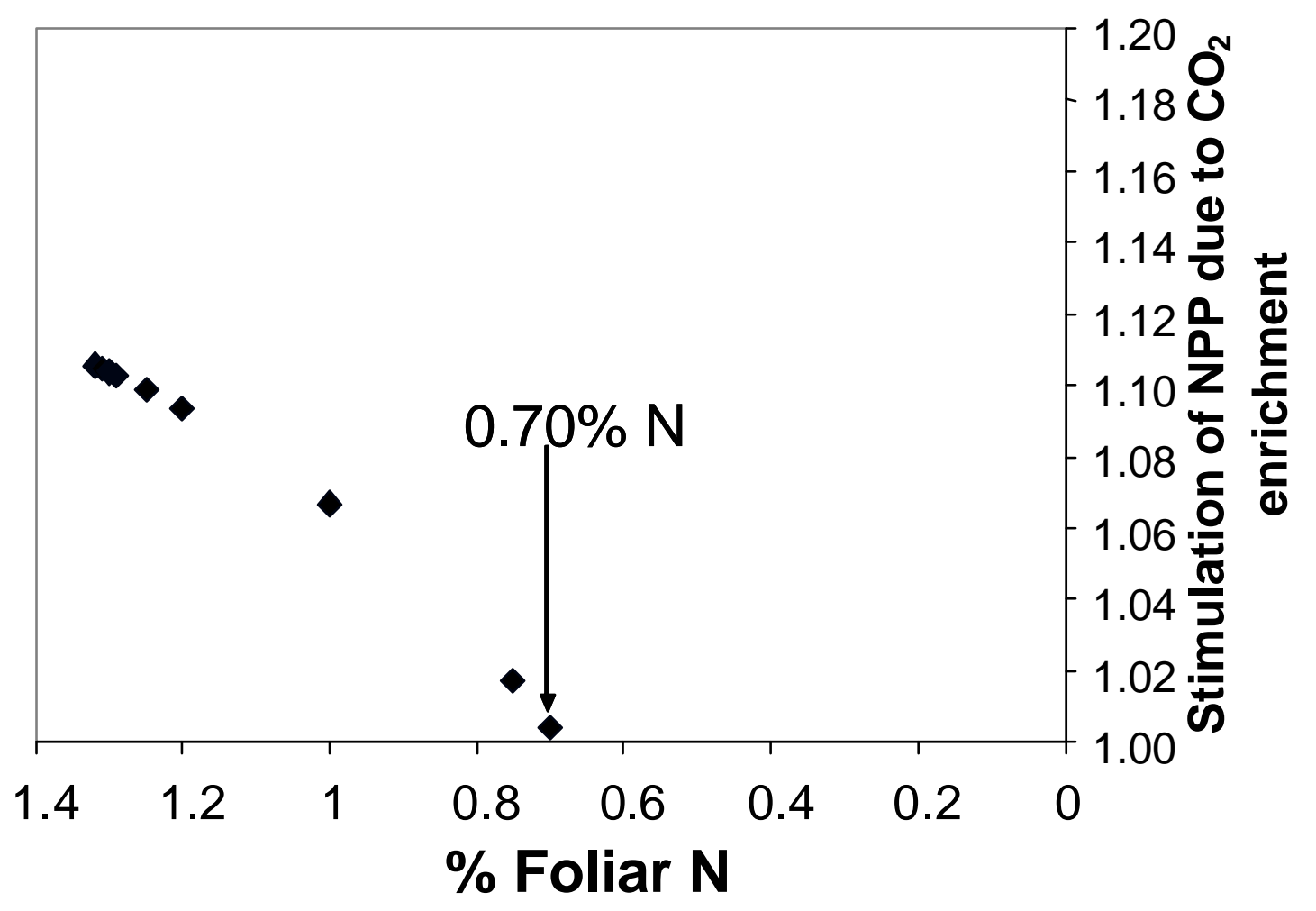




\section{General Conclusions}

Global climate change has the potential to alter forest ecosystem functioning and productivity, therefore understanding the physiological mechanisms that control forest function and productivity, such as photosynthesis, is extremely important. Also of great importance is our understanding of the interactions of these controlling mechanisms with the large degree of environmental heterogeneity found in a natural ecosystems and how these mechanisms change with time. The purpose of the research in this dissertation is to provide insight into the interactions of the response of photosynthesis to elevated $\mathrm{CO}_{2}$ with factors that may vary in a forest ecosystem, such as foliar $\mathrm{N}$ concentration, light availability, water availability, genetic differentiation, and intra- and inter-annual climate variability and to provide an early modeled estimate of a loblolly pine forest net primary productivity growing under ambient and elevated $\mathrm{CO}_{2}$.

My first experiment found that the strong relationship that exists between foliar $\mathrm{N}$ concentration and photosynthesis is stimulated by growth in elevated $\mathrm{CO}_{2}$ at the Duke FACE experiment. The slope of this relationship was increased by $81 \%$. I hypothesized that as the increased demand for $\mathrm{N}$ with growth in elevated $\mathrm{CO}_{2}$ exceeded the rate of supply of $\mathrm{N}$ that the response of photosynthesis to elevated $\mathrm{CO}_{2}$ and ultimately the photosynthesis-foliar $\mathrm{N}$ relationship would be altered. This hypothesis was based on the observation found in many long-term elevated $\mathrm{CO}_{2}$ studies of a decreased response of photosynthesis to elevated $\mathrm{CO}_{2}$ that is typically associated with a decrease in foliar N (Curtis and Wang 1998). However, the increase of the slope of this relationship was sustained through the study period and photosynthesis-foliar $\mathrm{N}$ relationships measured at common $\mathrm{CO}_{2}$ concentrations provided no evidence of changes in the photosynthetic response to elevated $\mathrm{CO}_{2}$ or foliar $\mathrm{N}$ concentration with growth in elevated $\mathrm{CO}_{2}$. 
The increased slope of this relationship under elevated $\mathrm{CO}_{2}$ represents an increased PNUE of trees growing in elevated $\mathrm{CO}_{2}$. This higher PNUE is the consequence of a reduction of the competitive inhibition of oxygen on RUBISCO activity and hence, photorespiration, at the carboxylation site.

My second study was a detailed analysis of the photosynthetic response of four species growing in the forest understory to elevated $\mathrm{CO}_{2}$ and light availability at the Duke FACE experiment. This study compared the photosynthetic response of these four species after seven years of $\mathrm{CO}_{2}$ enrichment to a study that investigated the same topic in the first year of treatment. I hypothesized that after 7 years of $\mathrm{CO}_{2}$ enrichment I would observe a change in the investment of resources in the leaf toward light harvesting and away from $\mathrm{CO}_{2}$ uptake because of the decrease in $\mathrm{CO}_{2}$ limitation of photosynthesis found in an elevated $\mathrm{CO}_{2}$ environment and that this reinvestment would lead to a loss of photosynthetic stimulation by elevated $\mathrm{CO}_{2}$. I found no evidence of a loss of stimulation and in some species an up-regulation of the response of photosynthesis was observed. I also found no $\mathrm{CO}_{2}$ induced changes in light harvesting capacity of trees growing in elevated $\mathrm{CO}_{2}$. The current study and the previous study support the hypothesis that ground-rooted trees may not exhibit a decrease in the photosynthetic response to elevated $\mathrm{CO}_{2}$ as do trees growing in pots (Curtis and Wang 1998, Norby et al. 1999, Medlyn et al. 1999).

The objective of my third study was to determine if loblolly pine seedlings exhibit geographic differentiation in their response to elevated $\mathrm{CO}_{2}$ and water availability. To carry out this experiment I grew loblolly pine seedlings from four distinct geographic regions in ambient or elevated $\mathrm{CO}_{2}$ and three levels of water availability in a greenhouse. I hypothesized that a genotype by environment interaction would be evident where seedlings originating from wet 
areas would respond more to elevated $\mathrm{CO}_{2}$ when grown under high water availability and seedlings originating from drier climates would respond more to elevated $\mathrm{CO}_{2}$ when grown under drought conditions. I found no significant interactions between growth in elevated $\mathrm{CO}_{2}$ and geographic origin. However, I did observe increased biomass production irrespective of geographic origin. I also observed changes in biomass allocation under varying levels of water availability. I concluded, because of strong support for geographic patterns of biomass allocation and production observed in earlier more long-term studies, that the topic deserves more study under long-term elevated $\mathrm{CO}_{2}$ and drought conditions.

My final study was performed to provide model estimates of the net primary productivity $(N P P)$ of the portions of the loblolly pine forest growing under ambient and elevated $\mathrm{CO}_{2}$ at the Duke FACE experiment and to determine the effects of projected future climate changes on the $\mathrm{CO}_{2}$ response of forest NPP using the PnET-II (Aber and Federer 1992) forest productivity model. I found good agreement between modeled $N P P$ and measured $N P P$ at the Duke FACE experiment. I also observed a $15 \%$ stimulation of $N P P$ across all years of the experiment. Increased temperature and precipitation did not alter the stimulation of $N P P$ by elevated $\mathrm{CO}_{2}$. However, increased temperature precipitation did result in much higher NPP. My estimates of NPP under future climate conditions however, were much larger than those predicted by others (Sun et al. 2000). I attributed the differences observed between my model estimates and those of others to changes in leaf level physiology not accounted for by the PnET-II model that may occur with large fluctuations in climate. 


\section{References}

Aber, J.D. and A. Federer 1992. A generalized, lumped-parameter model of photosynthesis, evapotranspiration and net primary production in temperate and boreal forest ecosystems. Oecologia. 92:463-474.

Curtis, P. and X. Wang 1998. A meta-analysis of elevated $\mathrm{CO}_{2}$ effects on woody plant mass, form, and physiology. Oecologia. 113:299-313.

Gunderson, C.A. and S.D. Wullschleger. 1994. Photosynthetic acclimation in trees to rising atmospheric $\mathrm{CO}_{2}$ : a broader perspective. Photosynthesis Research 39, 369-388.

Medlyn B.E., F.W. Badeck, D.G.G.De Pury, C.V.M. Barton, M. Broadmeadow, R. Ceulemans, P. De Angelis, M. Forstreuter, M.E. Jach, S. Kellomaki, E. Laitat, Marek M., Philippot S., Rey A., Strassemeyer J., Laitinen K., Liozon R., Portier B., Roberntz P., Wang K. and Jarvis P.G. 1999.Effects of elevated [CO2] on photosynthesis in European forest species: a meta-analysis of model parameters. Plant, Cell and Environment 22: 1475-495.

Norby R.J, Wulleschleger S.D., Gunderson C.A., Johnson D.W. and Ceulmans R. 1999. Tree responses to rising $\mathrm{CO}_{2}$ in field experiments: implications for the future forest. Plant, Cell and Environment 22: 683-714.

Reynolds J.F., Kemp P.R., Acock B., Chen J. and Moorhead D.L. 1996. Progress, limitations and challenges in modeling the effects of elevated $\mathrm{CO}_{2}$ on plants and ecosystems. In: Carbon dioxide and terrestrial ecosystems. (eds. G.W. Koch and H.A. Mooney), pp. 347-379. Academic Press, San Diego.

Strain, B.R., K.O. Higginbotham, J.C. Mulroy. 1976. Temperature preconditioning and photosynthetic capacity of Pinus taeda L. Photosynthetica 10: 47-53.

Sun, G., D.M. Amatya, S.G. McNulty, R.W. Skaggs and J.H. Hughes 2000. Climate change impacts on the hydrology and productivity of a pine plantation. Journal of the American Water Resources Association. 36:367-374. 


\section{CLINT J. SPRINGER}

Department of Ecology and Evolutionary Biology

University of Kansas

1200 Sunnyside Ave.

Lawrence, KS 66045

(785) 864-5229

cjs@ku.edu

\section{EDUCATION}

1999-2004 Ph.D. in Biology, West Virginia University, Morgantown, WV

1995-1999 B.A. in Biology, West Virginia University, Morgantown, WV

\section{RESEARCH EXPERIENCE AND EMPLOYMENT}

July 2004 - Present

University of Kansas, Postdoctoral Research Fellow, Dept. of Ecology and Evolutionary Biology

Supervisor: Dr. Joy Ward

May 1999 - June 2004

West Virginia University, Graduate Research and Teaching Assistant, Dept. of Biology

Dissertation Advisor: Dr. Richard B. Thomas

May 1997- August 1998

West Virginia University, Undergraduate Research Assistant, Dept. of Biology

Supervisor: Dr. William T. Peterjohn

\section{TEACHING EXPERIENCE}

May 2000 - August 2003

National Science Foundation Graduate Teaching Fellow, Eberly College of Arts and Sciences, West Virginia University

Supervisor: Dr. Fred L. King

August 1998-May 2000

Graduate Teaching Assistant

Dept. of Biology, West Virginia University

Supervisor: Dr. Jonathan Cumming 